\title{
EMPREGO DE INFILTRÔMETROS NA CARACTERIZAÇÃO DA INTERAÇÃO ENTRE RIO E AQÜÍFERO.
}

\author{
EUDES JOSÉ ARANTES
}

Dissertação apresentada à Escola de

Engenharia de São Carlos, da

Universidade de São Paulo, como parte dos requisitos para obtenção do título de Mestre em Hidráulica e Saneamento.

ORIENTADOR: Prof. Dr. Fazal Hussain Chaudhry

São Carlos 
"Para um apóstolo moderno, uma hora de estudo é uma hora de oração." (Josemaría Escrivá) 


\section{DEDICATÓRIA}

Aos meus pais, à minha querida esposa Elisângela e à criança que está para vir e alegrar nossas vidas. 


\section{AGRADECIMENTOS}

Ao estimado Prof. Dr. Fazal Hussain Chaudhry, meu orientador pelos ensinamentos, apoio, dedicação. Aos professores do SHS: Dr. Edson C. Wendland, Dr. Harry Edmar Schulz, Dr. Eduardo Mario Mendiondo e Dr. Rodrigo de Melo Porto pelas sugestões.

Aos funcionários do Centro de Recursos Hídricos e Ecologia Aplicada: Beto, Miro, Rogério, João, Osni, Maurício, Marcelo, Amandio e Lucy pela ajuda nas campanhas de campo e nos ensaios nos laboratórios.

Além da dedicatória, agradeço minha esposa e meus pais, por proporcionarem os melhores momentos de minha vida.

Agradeço também meus amigos: Fábio, Giovani, Antenor, Caruso, Roberto, Zozó, Lobão, Cláudião, Boris, “Andréias”, Tina, Velhinho, Barte, Vermelho, Eric, Anderson, Alexandre, Johannes, Klebber, Peter, Stênio, Giorgio, Fernando, José Eduardo, Alessandra e todos os que por ventura não tenha sido citados.

Agradeço, em especial, a Deus , que me dá saúde, a capacidade de me empenhar nas pesquisas e a felicidade de ter ao meu lado tantas pessoas amigas.

A Fundação de Amparo à Pesquisa do Estado de São Paulo - FAPESP, pela bolsa de estudo concedida. 
SUMÁRIO

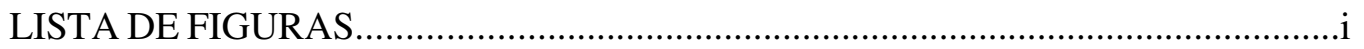

LISTA DE TABELAS...................................................................................

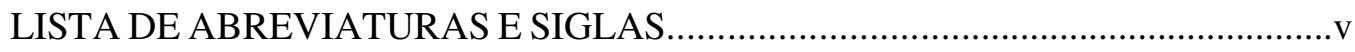

LISTA DE SÍMBOLOS............................................................................... vi

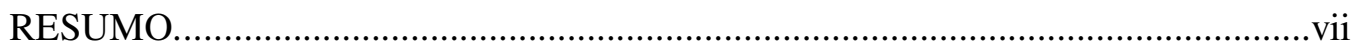

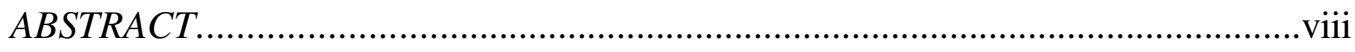

1. INTRODUÇÃ

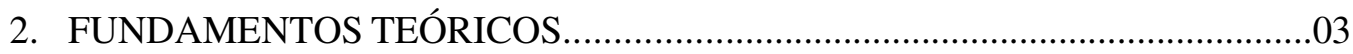

2.1. Águas Subterrâneas....................................................................................

2.1.1. Conceitos Básicos de Hidrogeologia...............................................03

2.1.2. Movimento das Águas Subterrâneas...............................................05

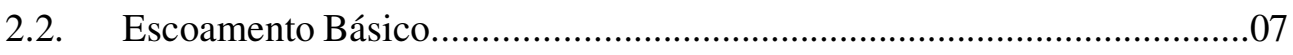

2.3. Interação Água Subterrânea e Superficial.................................................08

2.3.1. O Ciclo Hidrológico e a Interação da Água Subterrânea e

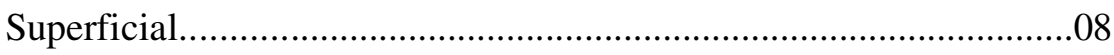

2.3.2. Conceitos de Água Subterrânea, Nível D’água e Sistemas de



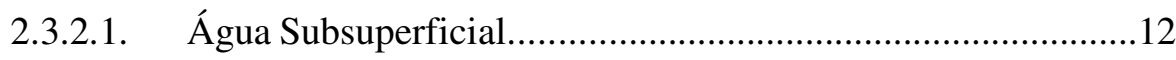

2.3.2.2. O Nível D’água do Lençol Freático......................................14

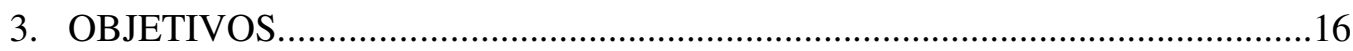

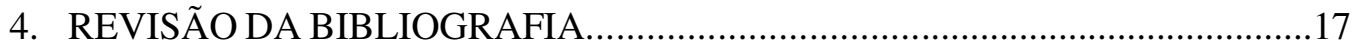

4.1. Interação Rio x Aqüífero.............................................................. 17 
4.2. Medidas de Trocas: Rio e Aqüífero......................................................22

4.2.1. A Utilização de Infiltrômetros...........................................................24

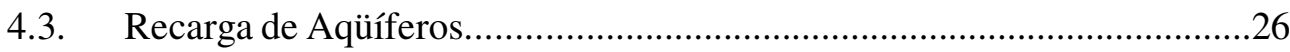

4.4. Flutuação do Nível D'água em Aqüíferos............................................29

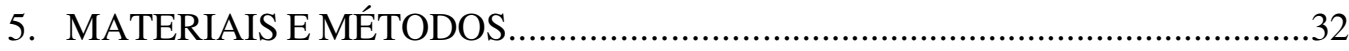

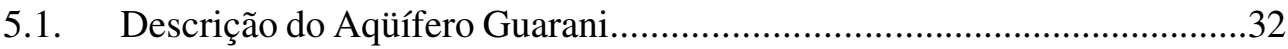

5.2. $\quad$ A Bacia do Ribeirão da Onça...................................................................35

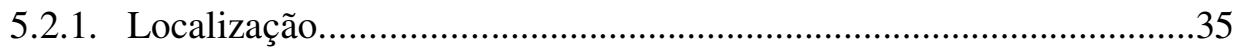

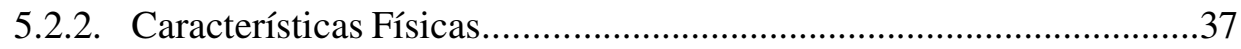

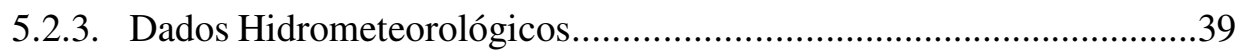

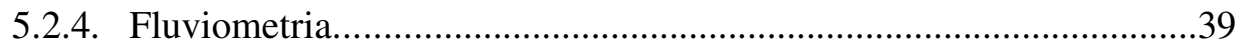

5.3. Descrição dos Infiltrômetros...............................................................41

5.3.1. Emprego de Infiltrômetros..............................................................41

5.3.2. Experimento de Campo - Primeira Etapa........................................42

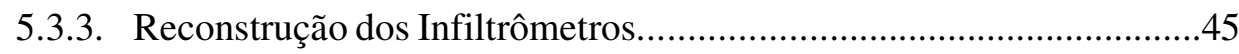

5.3.4. Coletores de Surgimento Aprimorados...........................................47

5.3.5. Teste com o Equipamento Aprimorado e o Recipiente Plástico.........47

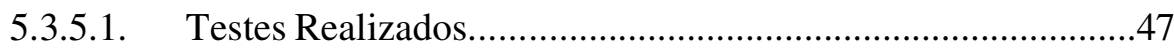

5.3.5.2. Resultados dos Testes......................................................49

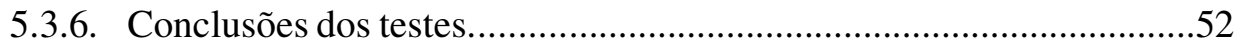

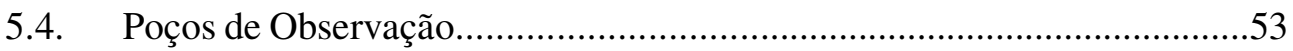

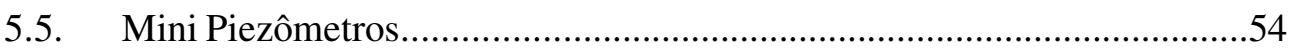

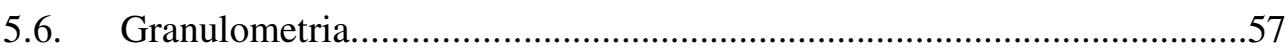

5.6.1. Descrição do Ensaio Granulométrico.............................................57 


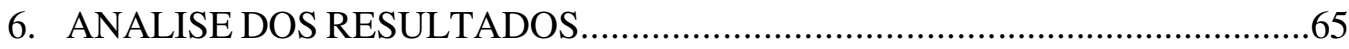

6.1. Medidas da Interação Rio - Aqüífero....................................................64

6.2. Variação Temporal da Vazão do Ribeirão da Onça..................................68

6.3. Uma Estimativa da Grandeza da Taxa de Surgimento..........................69

6.4. Determinação da Condutividade Hidráulica Através de Mini Piezômetros

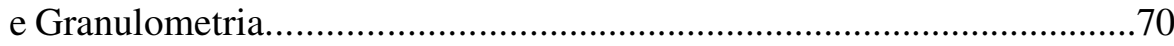

6.5. Variação dos Níveis Freáticos..............................................................72

6.6. Análise da Influência da Pressão Atmosférica e da Cota do Rio sobre o

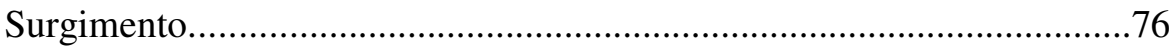

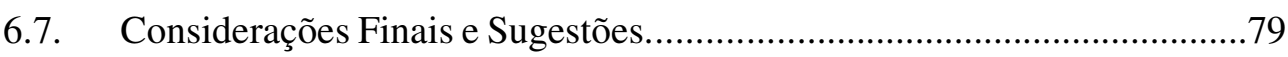

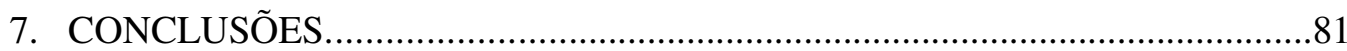

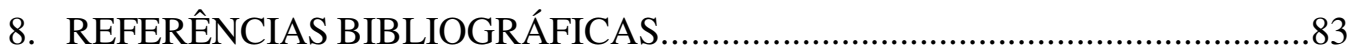




\section{LISTAS DE FIGURAS}

FIGURA 01 - Divisão da água abaixo da superfície (TODD, 1967).....................................04

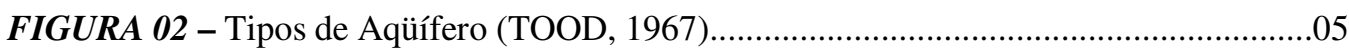

FIGURA 03 - Generalização do Experimento de Darcy........................................................

FIGURA 04 - Separação do Escoamento Básico (CONTIN, 1987).......................................08

FIGURA 05 - Esquematização do Ciclo Hidrológico (WINTER et al. 1998)......................09

FIGURA 06 - Interação água subterrânea e superficial das montanhas aos oceanos

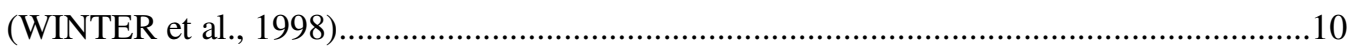

FIGURA 07 - Caminhos do fluxo subterrâneo (WINTER et al., 1998).................................12

FIGURA 08 - Divisão da água abaixo da superfície no encontro com o escoamento

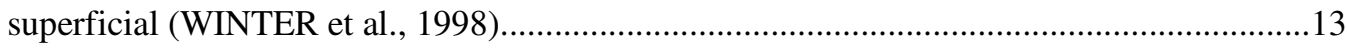

FIGURA 09 - Método para determinação do nível d'água e das linhas de fluxo (WINTER et

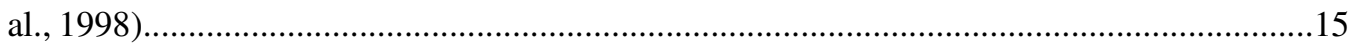

FIGURA 10 - Rio perdendo água para o aquífero $(\boldsymbol{A})$. Isto Pode ser determinado pelos mapas dos contornos do nível d'água, pois as linhas de contorno estão em direção favorável ao fluxo onde elas cruzam o rio $(\boldsymbol{B})$ .18

FIGURA 11 - Rio recebendo água do aquífero $(\boldsymbol{A})$. Isto Pode ser determinado pelos mapas dos contornos do nível d'água, pois as linhas de contorno estão em direção contrária ao fluxo

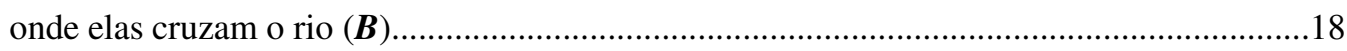

FIGURA 12 - Rio com infiltração e surgimento na mesma seção..........................................20

FIGURA 13 - Rio com infiltração apesar de um dos lados ter carga hidráulica maior que o escoamento superficial. .20

FIGURA 14 - Rio com surgimento apesar de um dos lados ter carga hidráulica menor que o escoamento superficial

FIGURA 15 - Rios "desconectados" são separados da água subterrânea por uma zona não saturada. . .20 
FIGURA 16 - Se os níveis do rio subir mais alto que os níveis da água subterrânea adjacentes, a água do rio move-se como Armazenamento de Margem. 20

FIGURA 17 - Se a elevação do nível d'água for mais alto que as margens do rio (C), a inundação recarrega o aqüífero ao longo das áreas inundadas..............................................22

FIGURA 18 - Infiltrômetro similar ao descrito por LEE (1977). .25

FIGURA 19 - Localização dos Afloramentos do Aqüífero Guarani em território brasileiro.34 FIGURA 20 - Localização da Bacia do Ribeirão da Onça........................................................36

FIGURA 21 - Planta Topográfica da Bacia do Ribeirão da Onça com Seções 1, 2 e 3.........38

FIGURA 22 - Fotos do Ribeirão da Onça na seção 3.............................................................39

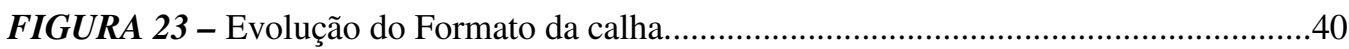

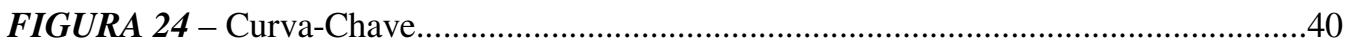

FIGURA 25 - Tambor cortado, com espigão, pintado e identificado.....................................43

FIGURA 26 - Sacola de plástico soldada e fixada à mangueira com registro........................43

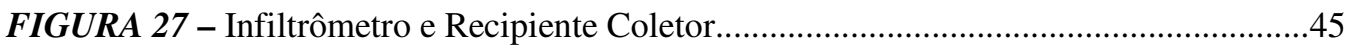

FIGURA 28 - Representação do Infilttrômetro Reconstruído...................................................46

FIGURA 29 - (a) Caixa de apoio para proteção do recipiente de plástico. (b) Acoplamento da mangueira ao bocal do recipiente plástico. .47

FIGURA 30 - Teste do Infiltrômetro e do recipiente plástico. .48

FIGURA 31 - Comparação da variação das alturas manométricas dos infiltrômetros 1 e 2 com acréscimo de 1 litro.

FIGURA 32 - Comparação da variação das alturas manométricas dos infiltrômetros 1 e 2 com acréscimo de 5 litros .51

FIGURA 33 - Comparação da variação das alturas manométricas dos infiltrômetros com acréscimo de 5 litros com e sem recipiente de plástico. .52

FIGURA 34 - Tubos de PVC perfurados com geotêxtil e os trados tipo concha...................53

FIGURA 35 - Mini-piezômetro similar ao descrito por LEE e CHERRY (1978)..................55

FIGURA 36 - Mini-piezômetro aprimorado. .56 


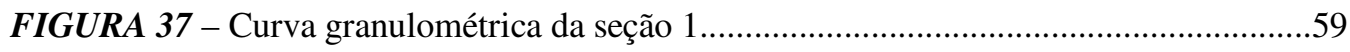

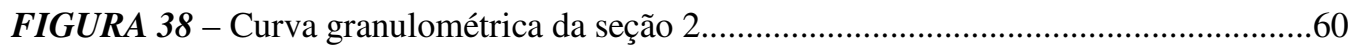

FIGURA 39 - Curva granulométrica da seção 3 (Camada 1)................................................61

FIGURA 40 - Curva granulométrica da seção 3 (Camada 2).............................................62

FIGURA 41 - Curva granulométrica da seção 3 (Camada 3).............................................63

FIGURA 42 - Curva granulométrica da seção 3 (Camada 4)................................................64

FIGURA 43 - Interação rio-aqǘfero nas seções 1, 2 e 3.................................................66

FIGURA 44 - Variação da pressão atmosférica no horário da visita ao campo......................66

FIGURA 45 - Precipitação diária durante o período dos ensaios..........................................67

FIGURA 46 - Comparação das médias mensais do surgimento nas seções 1, 2 e 3.............67

FIGURA 47 - Hidrograma no período de estudo (Com separação do escoamento superficial e básico)

FIGURA 48 - Variações das cotas do nível d'água e dos poços de observação nas proximidades da seção 1 e precipitação......

FIGURA 49 - Variações das cotas do nível d'água do rio e dos poços de observação próximo à seção 2 e precipitação. . .73

FIGURA 50 - Seção transversal para representação do nível freático na seção 1 ...................74

FIGURA 51 - Seção transversal para representação do nível freático na seção 2..................75

FIGURA 52 - Comparação entre os valores do surgimento e a pressão atmosférica na hora do ensaio, em épocas de estiagem (seção 1).......................................................................76

FIGURA 53 - Comparação entre os valores do surgimento e a pressão atmosférica na hora do ensaio, em épocas de estiagem (seção 2).

FIGURA 54 - Comparação entre os valores do surgimento e a pressão atmosférica na hora

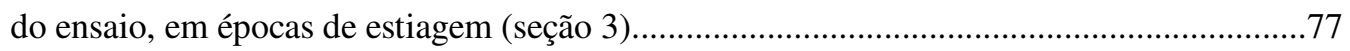

FIGURA 55 - Influência da pressão atmosférica..............................................................

FIGURA 56 - Variação do Surgimento com o Nível d'água no Ponto 2................................79 


\section{LISTA DE TABELAS}

TABELA 01 - Sumário dos Mecanismos que Conduz à Flutuação do Nível de Água

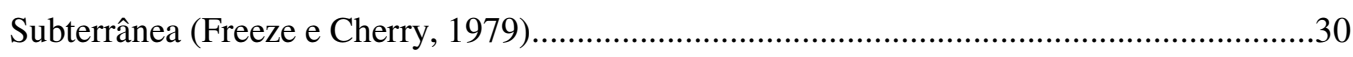

TABELA 02 - Valores da taxa de surgimento (mm/dia) para as três Seções de Estudo........68

TABELA 03 - Determinação da Condutividade Hidráulica na Seção 3................................71

TABELA 04 - Estimativa da Condutividade Hidráulica.......................................................72 


\section{LISTA DE ABREVIATURAS E SIGLAS}

CRHEA - Centro de Recursos Hídricos e Ecologia Aplicada.

SAEP - State Agency of Enviromental Protection. 


\section{LISTA DE SIMBOLOS}

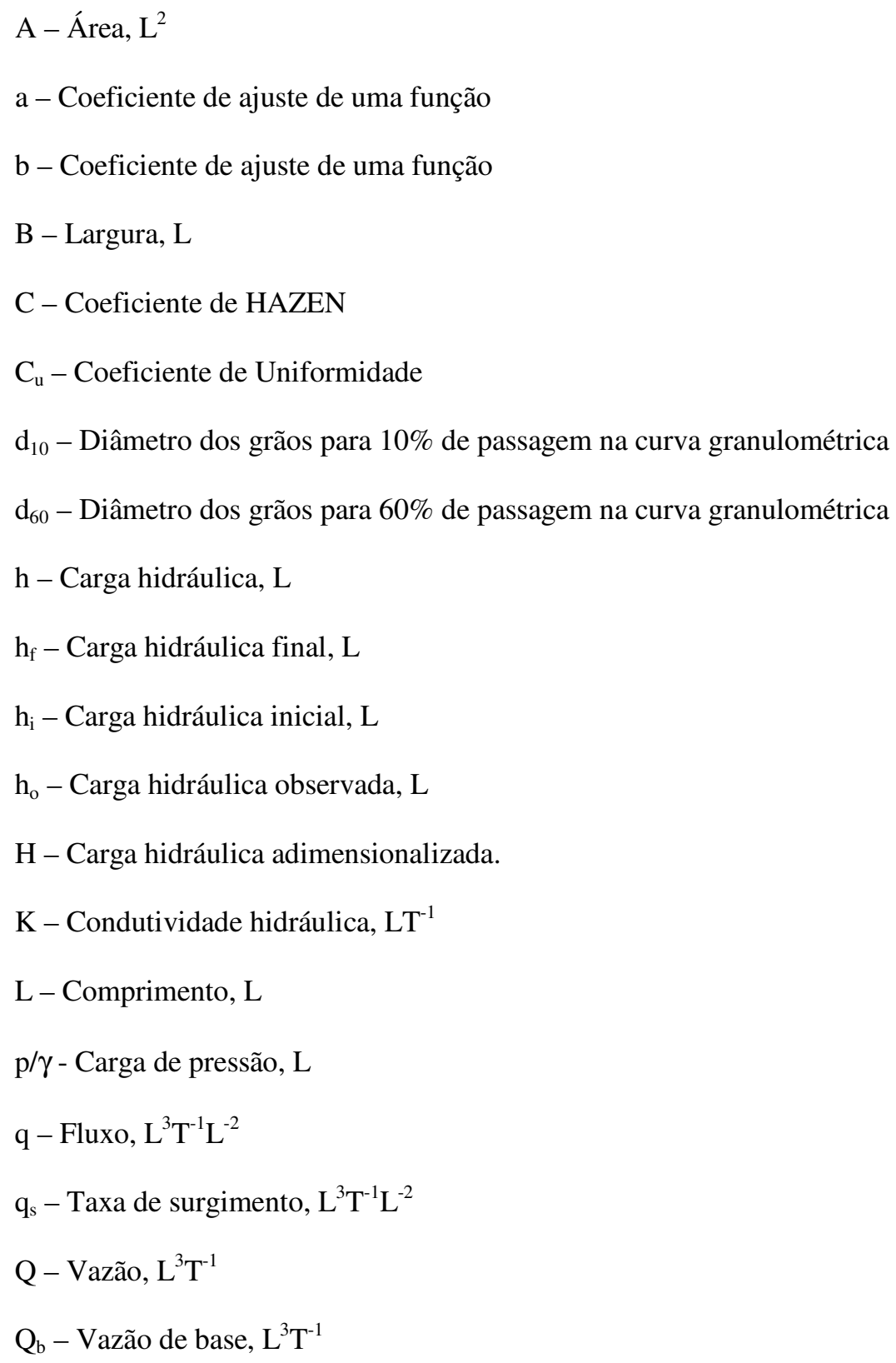




\section{RESUMO}

ARANTES, E. J. (2003). Emprego de Infiltrômetros na Caracterização da Interação entre Rio e Aqüífero. São Carlos, 2003. 86p. Dissertação (Mestrado) - Escola de Engenharia de São Carlos, Universidade de São Paulo.

O presente trabalho visa a quantificação do escoamento de água na interação entre rio e aqüífero subterrâneo em uma bacia, através da utilização de infiltrômetros e de poços de observação de lençol freático na proximidade do rio. O Ribeirão da Onça, um afluente do rio Jacaré-Guaçú localizado no município de Brotas no estado de São Paulo, foi escolhido para a realização deste estudo sendo a sua bacia hidrográfica pertencente a importante área de recarga do aqüífero Guarani. O estudo da interação rio aquiífero foi realizado através de infiltrômetros colocados em três seções deste rio. Analisando-se o comportamento da interação ao longo de um período de 7 meses, verificou-se que a taxa média de surgimento foi de $300 \mathrm{~mm} / \mathrm{dia}$ na área de afloramento do lençol freático. Ainda, observou-se a influência da chuva e da pressão atmosférica nos valores do surgimento, sendo a última de forma inversa. Tendo em vista os resultados satisfatórios dos experimentos, a utilização de infiltrômetros para determinação da taxa de troca entre rio e aqüífero representa um procedimento simples e adequado, mas requer cuidados contínuos para obter-se resultados consistentes.

Palavras-chaves: Interação rio e aqüífero, Infiltrômetro, Águas subterrâneas, Aquiífero Guarani, Escoamento básico. 


\section{ABSTRACT}

ARANTES, E. J. (2003). The Use of Infiltrometers for the Characterization of RiverAquifer Interaction. São Carlos, 2003. 86p. Dissertação (Mestrado) - Escola de Engenharia de São Carlos, Universidade de São Paulo.

The purpose of this work is to quantify the river-aquifer interaction in a river basin through the use of infiltrometers and observation wells located on the banks. Onça Creek, a tributary of the Jacaré-Guaçú River in the State of São Paulo, was chosen for this study being located in the recharge area of the regional Guarani Aquifer. Infiltrometers were placed at three sections in the bed of Onça Creek. Analyzing the behavior of the river-aquifer interaction during 7 months, it is found that the average exfiltration rate is of the order of $300 \mathrm{~mm} /$ day in the seepage area. Further, the seepage rate is found to be influenced by rainfall events, atmospheric pressure and rate of rise or fall of river stage. In view of the satisfactory experimental results obtained in this study, the use of infiltrometers for the determination of the river-aquifer interaction is recommended as a simple and sound procedure if due care is taken in their installation in the river bed.

Key words: River-aquifer interaction, Infiltrometer, Groundwater, Guarani Aquifer, Seepage. 


\section{INTRODUÇÃO.}

O constante movimento da água na atmosfera, na superfície da Terra, no subsolo ou nas grandes massas constituídas pelos oceanos, mares e lagos configura o que se convencionou chamar de ciclo hidrológico. Cabe à Engenharia Hidrológica quantificar os volumes armazenados e as quantidades transportadas entre os vários compartimentos terrestres.

A infiltração da água de chuva no solo ao longo de milhares de anos resultou na formação de reservas subterrâneas de grande valor para o abastecimento d'água urbano e rural, principalmente pelo volume d'água disponível e pela qualidade dessas águas. As águas subterrâneas armazenadas em formações aluvionares de pequena profundidade formam os lençóis freáticos e exercem papel fundamental na regularização das vazões dos cursos d'águas nos períodos de estiagem.

A interação entre rio e aquiífero é um elo do ciclo hidrológico que é importante para o estudo, tanto de recargas em aqüíferos, como na regularização de vazões do escoamento superficial. O entendimento da interação da água subterrânea e superficial é essencial ao estudo em recursos hídricos. O planejamento considerando apenas uma componente do sistema hidrológico, como um rio ou um aqüífero, normalmente, é só em parte

eficaz, porque cada componente hidrológica está em continua interação com outras componentes.

A quantificação da interação entre o rio e o aqüífero pode ser realizada através de diversas maneiras, tais como, infiltrômetros, míni-piezômetros, traçadores, lisímetros de 
fundo de rio, diferença entre vazões em um trecho do rio e também através do balanço hídrico.

O objetivo deste trabalho é a quantificação do escoamento de água na interação entre o rio e o aqüífero subterrâneo em uma bacia, através da utilização de infiltrômetros e de poços de observação do lençol freático na proximidade do rio. Assim, ensaios em diversas seções do rio foram propostos, de modo a verificar o comportamento do escoamento em seu leito e caracterizar a existência de infiltração ou surgimento e a taxa de troca.

A bacia do Ribeirão da Onça foi escolhida para a realização desse estudo. Esse pequeno rio é um afluente do rio Jacaré-Guaçú localizado no município de Brotas no estado de São Paulo e pertencente à importante área de recarga do aquífero Guarani. 


\section{FUNDAMENTOS TEÓRICOS.}

\section{1. Águas Subterrâneas.}

\subsubsection{Conceitos Básicos de Hidrogeologia.}

Os sistemas hidrogeológicos podem ser classificados em (TUCCI, 2001):

Aqüifferos, uma formação geológica (ou um grupo de formação) que contém água e permite que a mesma se movimente em condições naturais e em quantidades significativas.

Aquiclude, uma formação geológica que pode conter água, mas sem condições de movimentá-la de um lugar para outro, em condições naturais e em quantidades significativas.

Aquitardo, uma formação geológica de natureza semipermeável. Transmite água a uma taxa muito baixa, comparada com a do aqüífero.

A umidade do solo pode ser dividida em zonas de acordo com a proporção relativa do espaço poroso ocupado pela água (FIGURA 01). Assim:

$\mathrm{Na}$ zona de saturação (saturada), todos os espaços vazios encontram-se completamente ocupados pela água. Esta camada está limitada superiormente pela linha de saturação (superfície piezométrica) e em geral, por uma barreira impermeável, inferiormente. As fontes, os poços e as correntes efluentes têm origem na zona saturada. Na linha de saturação, a pressão da água é igual à pressão atmosférica.

Na zona de aeração (não-saturada), poros contêm água e ar (ou vapor de água). esta zona está limitada pela superfície do terreno e pela linha de saturação. Podem-se diferenciar três zonas: a zona de água do solo (cinturão de umidade onde as plantas se desenvolvem), a 
zona intermediária (serve como freio das chuvas intensas) e a zona capilar (formada pelo ascenso capilar).

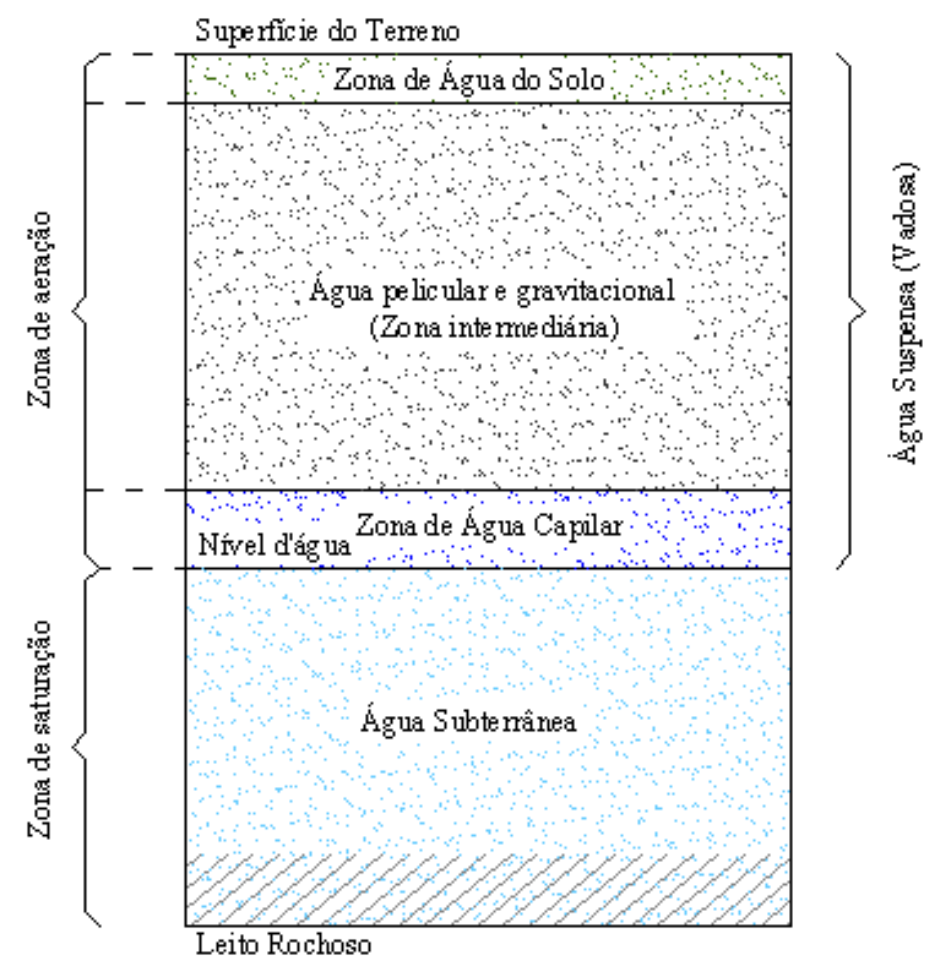

FIGURA 01 - Divisão da água abaixo da superfície (TODD, 1967).

Os aquíferos podem se classificados em confinados e não-confinados (livres), dependendo da ausência ou da presença da linha freática. O aqǘffero confinado encontra-se a uma pressão maior que a pressão atmosférica. Está limitado superior e inferiormente por formações impermeáveis. O aqüífero artesiano é um aqüífero confinado.

No aquíf́ero freático (livre), a superfície piezométrica (freática) serve como fronteira superior. Os aqüíferos confinados são geralmente aqüíferos de grande fornecimento de água, enquanto que os aqüíferos livres são os mais explorados devido ao fácil acesso. A FIGURA 02 mostra os principais tipos de aqüíferos. 


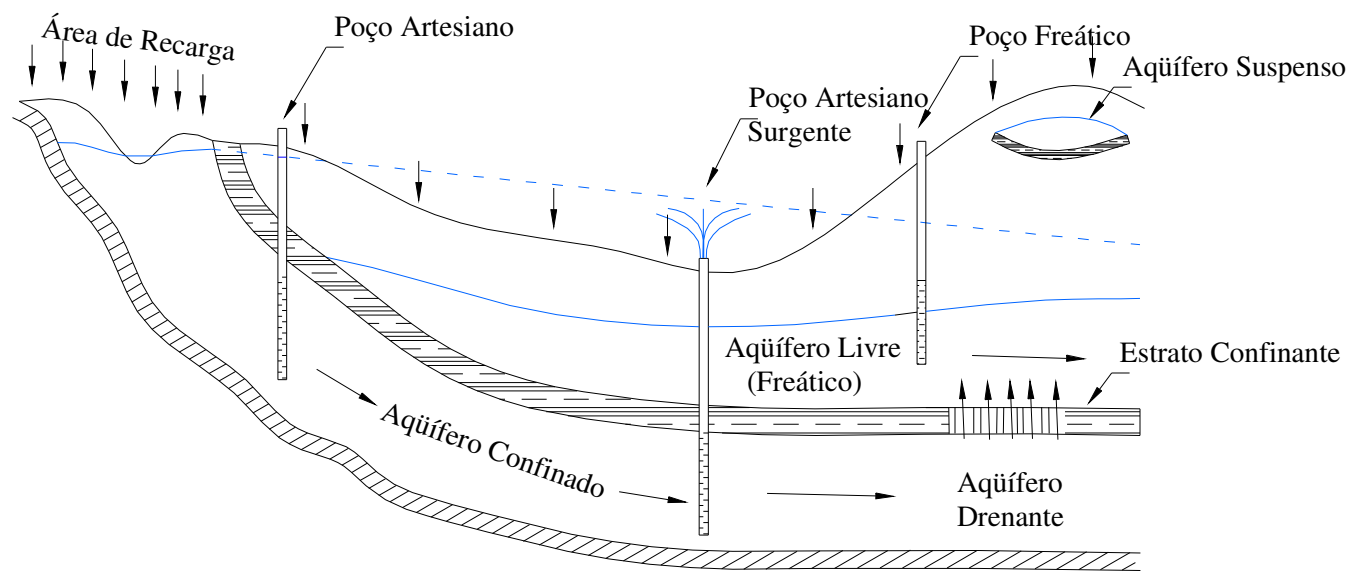

FIGURA 02 - Tipos de Aqüíferos (TOOD, 1967).

\subsubsection{Movimento das Águas Subterrâneas.}

As águas subterrâneas nos aqüíferos em seu estado natural encontram-se invariavelmente em movimento. Este movimento é governado por princípios hidráulicos estabelecidos. O fluxo através de aqüíferos, a maioria dos quais é um meio poroso natural, pode ser expresso pelo que é conhecido como Lei de Darcy. A condutividade hidráulica, que é a medida da facilidade com que o fluxo atravessa o meio, é um parâmetro importante na equação do fluxo.

\section{Lei de Darcy.}

Há praticamente um século e meio atrás HENRY DARCY (1856), um engenheiro hidráulico francês investigou o fluxo d'água através de cilindros de areia a serem utilizados para a filtração da água em uma fonte pública na cidade de Dijon na França. 


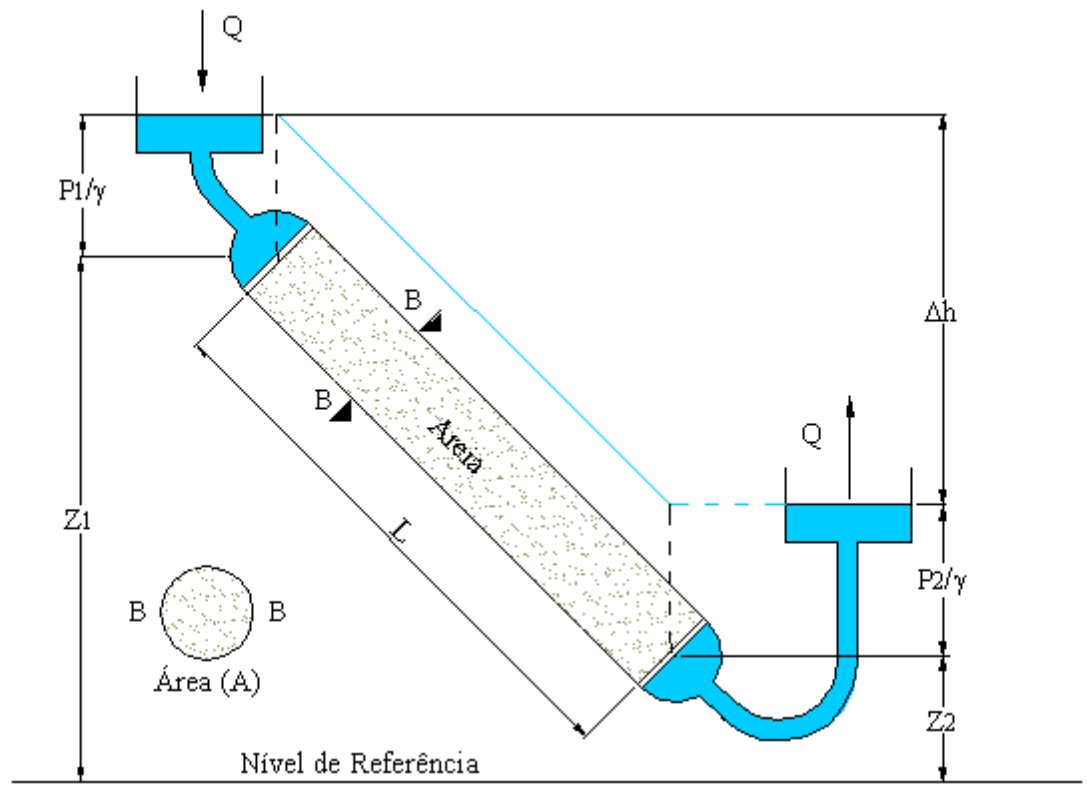

FIGURA 03 - Generalização do Experimento de Darcy.

A partir desses experimentos, concluiu que a taxa de fluxo ou vazão (volume de água por unidade de tempo) Q, num sistema como mostrado na FIGURA 03, era:

- proporcional à área da seção do filtro (A).

- proporcional à diferença de carga hidráulica $\left(\Delta h=h_{1}-h_{2}\right)$.

- inversamente proporcional ao comprimento L.

A parcela $\Delta h=\left(h_{1}-h_{2}\right)$ é a perda de energia devido ao movimento da água através do meio poroso com condutividade hidráulica $K, h$ é a carga hidráulica $(h=p / \gamma+z)$, $z$ é a carga de elevação a partir de um nível de referência, e $p / \gamma$ é a carga de pressão.

Diante destas conclusões, mais tarde, a expressão ficou conhecida como lei de Darcy e passou a ser escrita na forma diferencial:

$Q=-K A \frac{d h}{d L}$

O sinal negativo é indicação do fluxo na direção de cargas decrescentes. 
Definindo, $q=Q / A$ como a velocidade de Darcy, velocidade aparente ou ainda descarga específica, tem-se:

$q=-K \frac{d h}{d L}$

Em quase todos os campos da ciência e engenharia as técnicas de análise são baseadas em uma compreensão dos processos físicos, e na maioria dos casos é possível descrever estes processos matematicamente. Fluxo da água subterrânea não é exceção. A lei fundamental do fluxo é a lei de Darcy, que juntamente com a equação da continuidade, que descreve a conservação de massa do fluido durante o fluxo por um meio poroso, resulta em uma equação diferencial parcial (TOOD, 1967).

\subsection{Escoamento Básico.}

O escoamento básico é a parcela do escoamento em corpos d'água proveniente da água subterrânea, e é responsável pela perenidade e regularização das vazões em rios em períodos de estiagem. Fatores climáticos e fisiográficos determinam a contribuição da água subterrânea aos rios.

A quantidade de água que o aqüífero freático contribui ao rio pode ser estimada analisando o hidrograma na determinação da componente subterrânea (WINTER et al., 1998). O escoamento total do rio é separado em escoamento superficial e escoamento básico (FIGURA 04). Diversos métodos de analise de hidrogramas têm sido utilizados para determinar a componente do escoamento subterrâneo. 


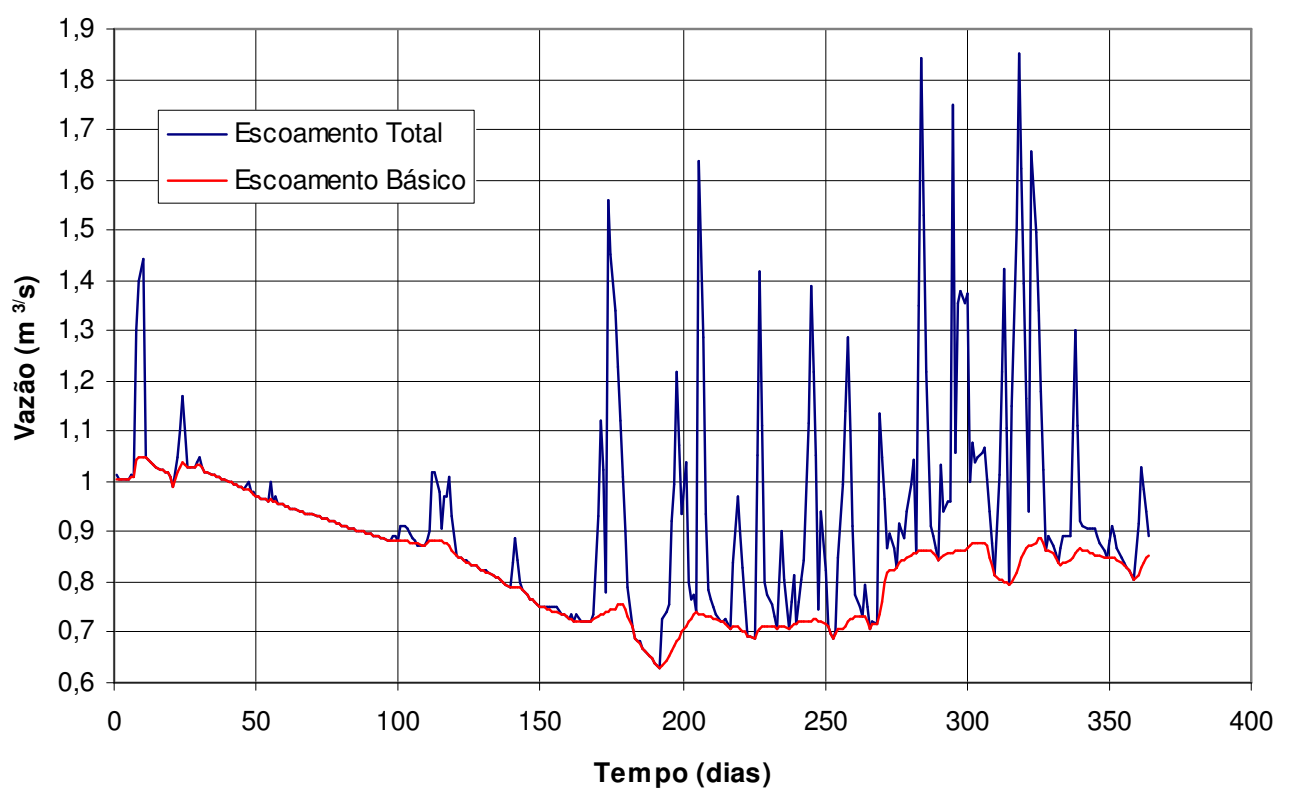

FIGURA 04 - Separação do Escoamento Básico (CONTIN, 1987).

\subsection{Interação Água Subterrânea e Superficial.}

\subsubsection{O Ciclo Hidrológico e a Interação da Água Subterrânea e Superficial.}

O ciclo hidrológico é o movimento da água, na atmosfera, na superfície da Terra, no subsolo ou nas grandes massas constituídas pelos oceanos, mares e lagos. Este ciclo é retratado comumente por um diagrama muito simplificado que mostra só as transferências principais de água entre continentes e oceanos, como na FIGURA 05. Porém, para compreender os processos hidrológicos e planejar os recursos hídricos, o ciclo hidrológico precisa ser visto de forma mais detalhada, conhecendo bem sua variabilidade no espaço e no tempo. A precipitação, que é uma das componentes de toda a água doce no ciclo hidrológico, cai quase em todos lugares, mas, sua distribuição é altamente variável. Semelhantemente, a evaporação e a transpiração devolvem água à atmosfera, mas as taxas de evaporação e transpiração variam consideravelmente de acordo com condições climáticas. Como 
resultado, muito da precipitação não chega aos oceanos como escoamento superficial ou subsuperficial, pois a água retorna à atmosfera. As magnitudes relativas das componentes individuais do ciclo hidrológico, como evapotranspiração, podem diferir significativamente até mesmo em escalas pequenas.

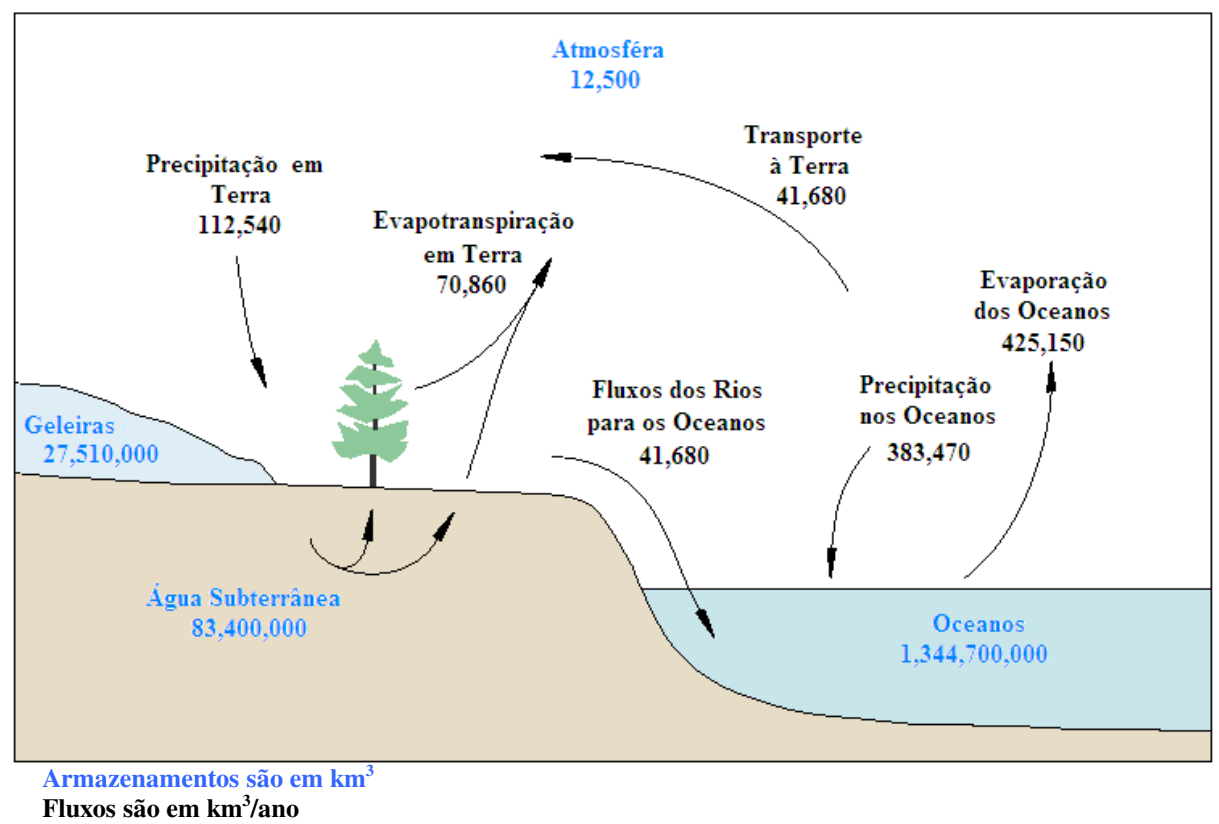

FIGURA 05 - Esquematização do Ciclo Hidrológico (WINTER et al. 1998)

As interações entre as águas de superfície e os aqüíferos podem ocorrer em todos os tipos de escoamentos superficiais, como rios, lagos, pântanos. A FIGURA 06 de WINTER et al. (1998) enfatiza essa interação, apresentando algumas linhas de fluxo, de forma simplificada, em diferentes seções de uma região. A interação entre água de superfície e aquíf́ero depende da colocação fisiográfica e climática da região. Por exemplo, um rio em um clima úmido pode receber água do aqüífero, mas um rio de fisiografia idêntica num clima árido pode perder água ao aqǘf́ro subterrâneo. Na FIGURA 06, visualiza-se, também, que a interação pode ocorrer em terrenos montanhosos, fluviais, costeiros, em depressões glaciais ou de dunas, como também em terrenos cársticos. Verifica-se que o movimento da água na interação rio-aqǘf́ero apresenta-se diferentemente dependendo da 
configuração do lençol freático nas proximidades do corpo d'água, que pode fornecer ou ser abastecido pelo aqüífero.

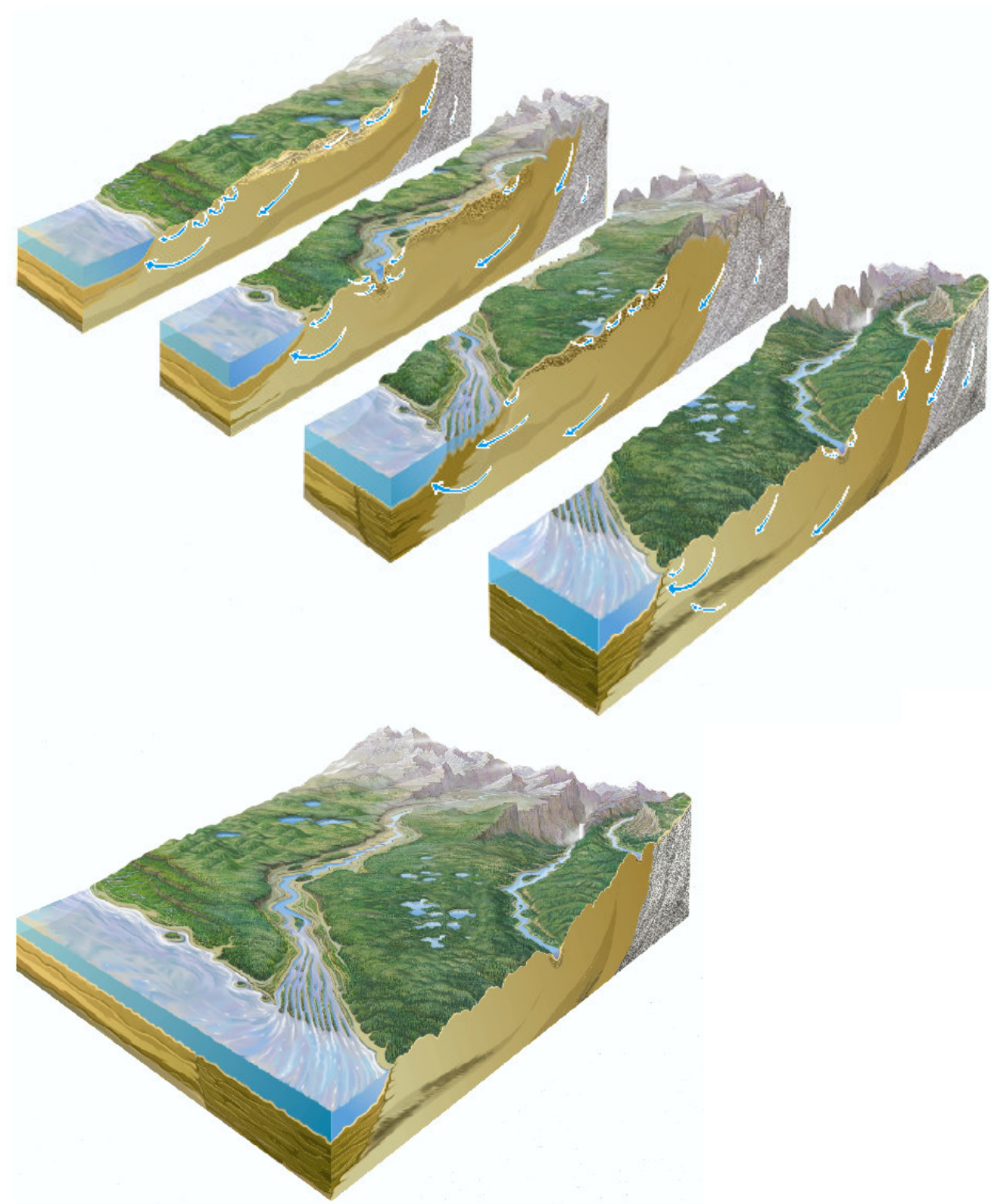

FIGURA 06 - Interação água subterrânea e superficial das montanhas aos oceanos.

(WINTER et al., 1998).

Movimento da água na atmosfera e na superfície de terra é relativamente mais fácil de visualizar do que movimento de água subterrânea. A água subterrânea move-se por linhas 
de fluxo de comprimentos diversos, das áreas de recarga para as áreas de descargas. As linhas de fluxo generalizadas na FIGURA 07 começam na superfície freática e continuam pelo sistema de água subterrânea, terminando no rio ou no poço de bombeamento.

A fonte de água para a superfície freática (recarga do aquífero) em geral é a infiltração da precipitação pela zona não saturada. Na parte superior do aquiífero nãoconfinado, as linhas de fluxo na proximidade do rio podem ter dezenas ou centenas de metros de comprimento e ter, ainda, tempos de residência correspondente a alguns dias ou anos. As linhas de fluxo mais longas e mais profundas na FIGURA 07 podem ter milhares de metros a dezenas de quilômetros de comprimento, e o tempo de residência pode variar de décadas a milênios. Em geral, água subterrânea rasa é mais suscetível à contaminação por fontes ou atividades humanas por causa de sua proximidade da superfície da terra (WINTER et al., 1998).

Características geológicas de pequena escala no fundo do corpo d'água afetam padrões de infiltração de escalas também pequenas conforme mostrado na FIGURA 07 (WINTER et al., 1998). Por exemplo, o tamanho, forma, e orientação do sedimento granular no fundo do corpo de água de superfície afetam esses padrões de interação. Se o fundo do corpo d'água de superfície consiste em um tipo de sedimento, como areia, o surgimento é maior na margem, diminuindo em direção ao centro deste corpo d'água. Unidades geológicas que também têm permeabilidades diferentes afetam a distribuição da infiltração no fundo da água de superfície. 




FIGURA 07 - Caminhos do fluxo subterrâneo (WINTER et al., 1998).

\subsubsection{Conceitos de Água Subterrânea, Nível D’água e Sistemas de Fluxo.}

\subsubsection{1. Água Subsuperficial.}

Como já foi apresentado no capitulo anterior, as águas abaixo da superfície da terra ocorrem em duas zonas principais, a zona não-saturada e a zona saturada (FIGURA 08). Na zona não saturada, os vazios - que são os espaços entre grãos de pedregulho, areia, silte, argila, e as falhas dentro das rochas - contêm ambos, ar e água. Embora uma quantia considerável de água possa estar presente na zona não saturada, esta água não pode ser bombeada através de poços porque são sustentadas pelas forças capilares. A parte superior da zona não saturada é a zona da água do solo. A zona da água do solo é cruzada por raízes, que deixam vazios quando deterioradas, e juntamente com os buracos feitos por animais e minhocas aumentam a infiltração da precipitação na zona do solo. A água do solo é usada 
pelas plantas para sobrevivência e transpiração, mas ela também pode evaporar diretamente para a atmosfera.

Ao contrário da zona não saturada, os vazios na zona saturada estão completamente cheios de água. A água na zona saturada é chamada água subterrânea. A superfície superior da zona saturada é chamada superfície freática (nível d'água). Debaixo do nível d'água, a pressão de água é suficiente para a entrada da água nos poços, permitindo retirar água subterrânea para uso (WINTER et al., 1998).

A espessura da zona vadosa do aqüífero freático é altamente variável e pode variar de zero, quando está na superfície da terra, a centenas de metros em alguns casos. Normalmente, a profundidade do lençol freático é pequena próxima de corpos d'água de superfícies permanentes, como rios, lagos, e pântanos. Uma característica importante do lençol freático é que sua configuração varia de acordo com a época, de um ano a outro, devido à recarga da água subterrânea, que é o acréscimo de água acima da superfície da zona saturada, e está relacionada à grande variação na quantidade, na distribuição, e no tempo de precipitação.

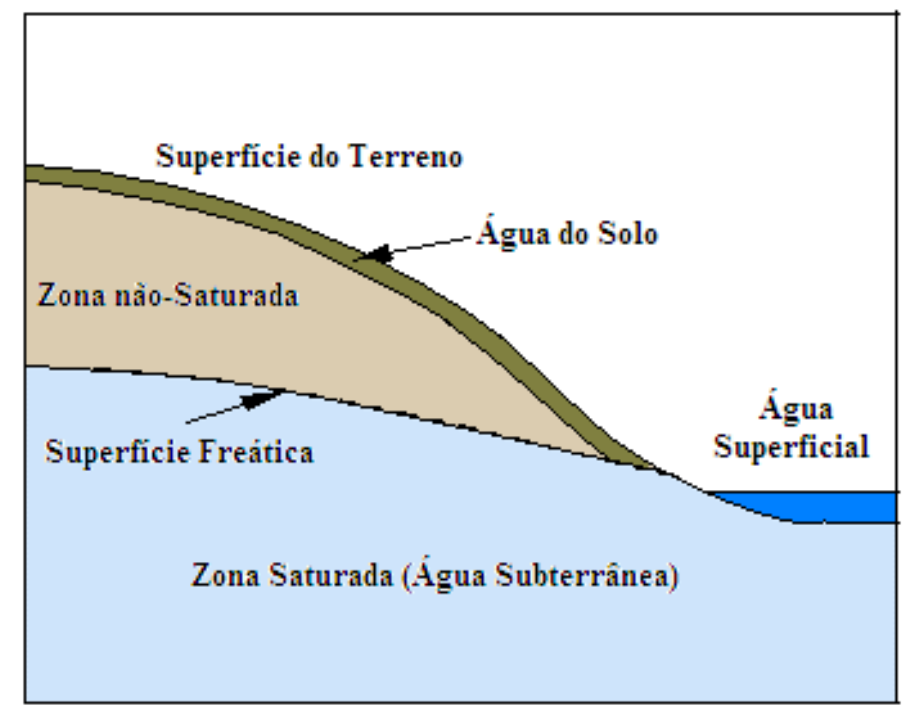

FIGURA 08 - Divisão da água abaixo da superfície no encontro com o escoamento superficial.

(WINTER et al., 1998) 


\subsubsection{O Nível D’água do Lençol Freático.}

O nível d'água do lençol freático pode ser determinado instalando-se poços que penetram na zona saturada a uma profundidade suficiente. A preparação de um mapa de níveis d'água requer a construção de poços de observação (FIGURA 09; WINTER et al., 1998). Se a profundidade da água é medida em vários poços ao longo de uma área de estudo, e se esses níveis de água tiverem uma referência comum, como o nível do mar, os dados podem ser interpolados para indicar a configuração do nível d'água (linhas equipotenciais FIGURA 09 B). Além de vários usos práticos de um mapa do nível d'água do lençol freático, como calcular uma profundidade aproximada para um poço proposto, a configuração da superfície freática pode indicar a direção aproximada do fluxo. Linhas, normalmente perpendiculares aos contornos dos níveis d'água, indicam a direção do sistema de água subterrânea (linhas de fluxo - FIGURA 09 C). A superfície freática se ajusta continuamente com as mudanças da recarga e os padrões de descarga. Então, para construir um mapa do nível d'água, devem ser feitas medidas do nível d'água aproximadamente ao mesmo tempo, e o mapa resultante só é representativo daquele tempo específico. 

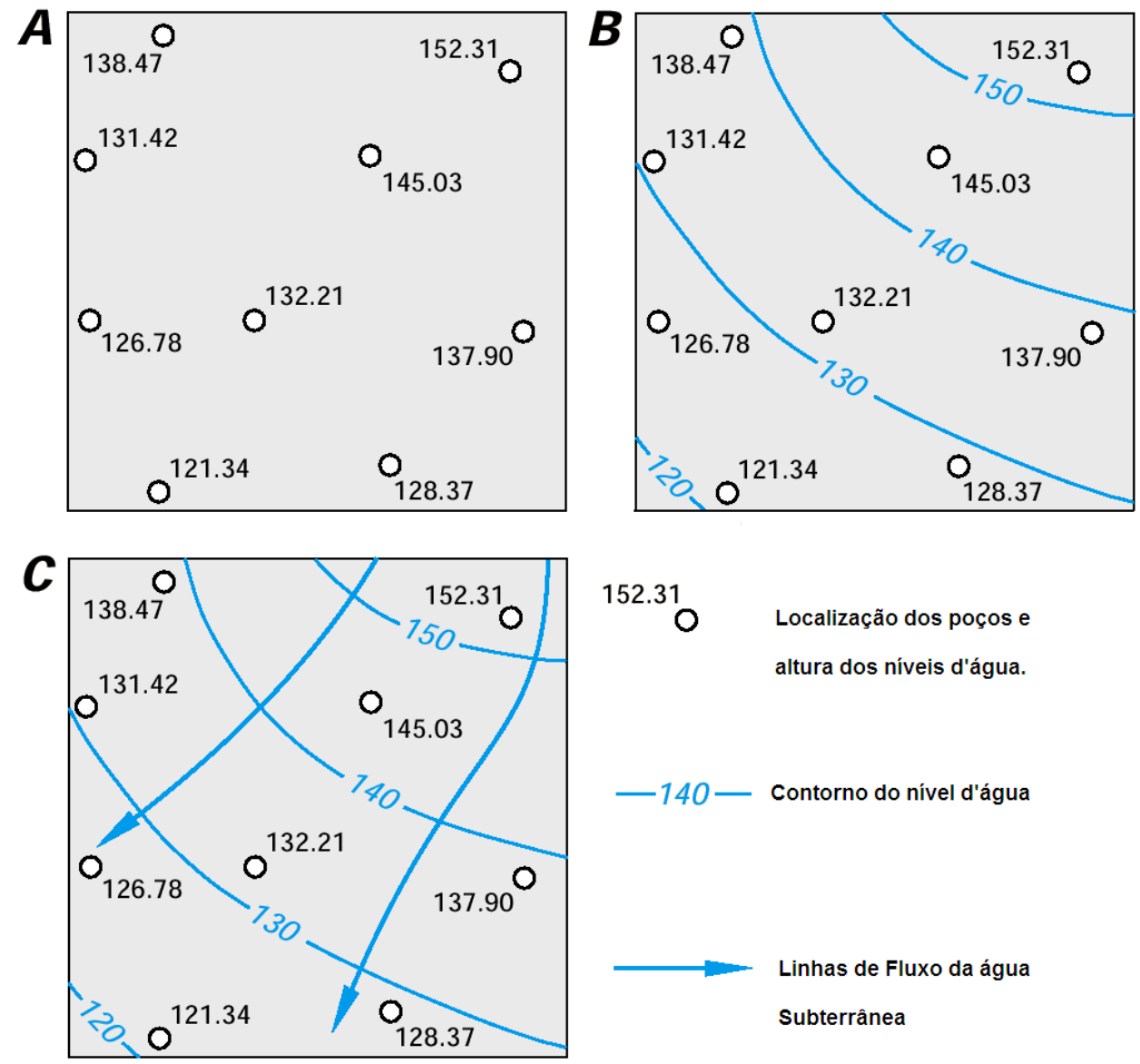

FIGURA 09 - Método para determinação do nível d'água e das linhas de fluxo.

(WINTER et al., 1998) 


\section{OBJETIVOS.}

Com base nas análises dos fundamentos teóricos verificou-se a necessidade do estudo da taxa de troca entre rios e aqüíferos subterrâneos, e a determinação do comportamento do escoamento no fundo do rio.

Objetiva-se, portanto, para este trabalho, o estudo do escoamento de água na interação entre o rio e o aqüífero subterrâneo no Ribeirão da Onça. Propõe-se determinar a variação temporal da taxa de troca por meio de infiltrômetros colocados no fundo deste rio em três locais ao longo do seu curso. Ainda, propõe-se instalar, nestes locais, baterias de poços de observação da variação do lençol freático na vizinhança do rio para caracterizar a configuração do escoamento na sua seção transversal. Tais experimentos têm como finalidade verificar o comportamento do escoamento na interação entre o Ribeirão da Onça e o lençol freático, quantitativamente e descritivamente. 


\section{REVISÃO DA BIBLIOGRAFIA.}

Para facilitar a apresentação do estudo da interação entre rio e aquiífero, a revisão bibliográfica foi dividida em quatro tópicos: $\mathrm{Na}$ primeira parte, apresentam-se as configurações possíveis do escoamento na interação rio $\mathrm{x}$ aqüífero. Na segunda, são abordados os métodos de medida da interação, em especial a utilização de infiltrômetros. $\mathrm{Na}$ terceira, o estudo da recarga de aqüíferos. Na última parte, alguns trabalhos relacionados ao estudo da flutuação do nível d'água em aqüíferos são apresentados.

\subsection{Interação Rio x Aqüífero.}

Rios pequenos são caracterizados por uma largura que é muito menor que a espessura do aqǘf́rero. Assumindo que o eixo do rio seja reto e a direção do fluxo da água subterrânea perpendicular ao seu eixo, o escoamento de troca é bidimensional neste plano. São mostradas configurações de fluxo típicas nas FIGURAS 10.A e 11.A (POLUBARINOVA-KOCHINA，1962，BEAR，1979, GELDNER e KALERIS，1980;

KALERIS, 1998; WINTER et al., 1998). Se o fluxo de troca contribui para o escoamento subterrâneo, então é caracterizado como infiltração FIGURA 10.A. Se a água subterrânea escoar para o rio, então o fluxo de troca é caracterizado como exfiltração ou surgimento FIGURA 11.A.

Para o aquífero descarregar no canal do rio, a altura do nível d'água freático na vizinhança do rio deve ser maior que a altura do rio. Reciprocamente, para água superficial infiltrar no aquífero, a altura do nível d'água na vizinhança do rio deve ser menor que a da 
superfície d'água. Visto em planta, quando a curva da elevação do nível d'água está a favor da corrente, o rio está perdendo água para o aqüífero (FIGURA 10.B). No caso em que a curva da elevação do nível estiver contra a corrente do rio, ele está ganhando água do aquífero (FIGURA 11.B), tudo isso nas proximidades do rio (WINTER et al., 1998).

$$
\text { Infiltração }
$$

$A$

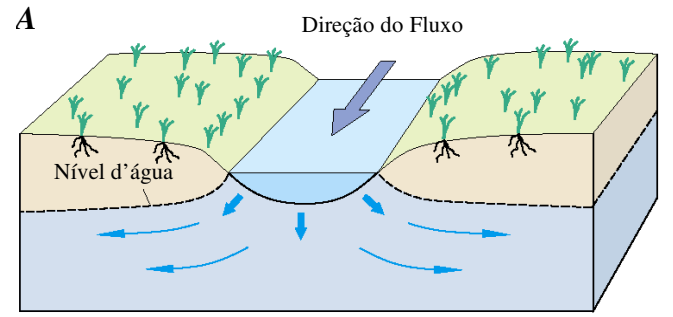

$\boldsymbol{B}$

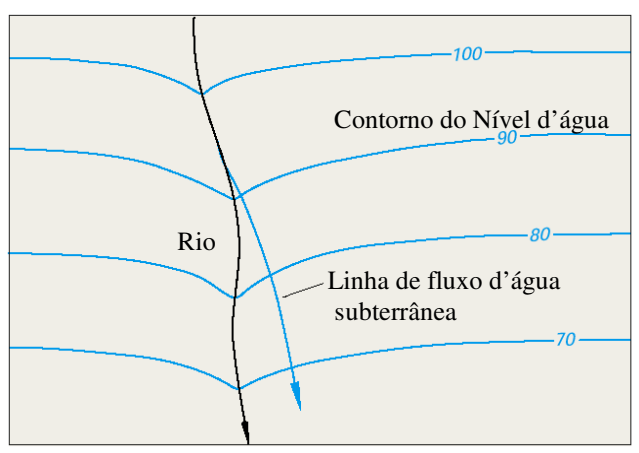

FIGURA 10 - Rio perdendo água para o aqüífero

$(\boldsymbol{A})$. Isto Pode ser determinado pelos mapas dos contornos do nível d'água, pois as linhas de contorno estão em direção favorável ao fluxo onde elas cruzam o rio $(\boldsymbol{B})$.
A Direção do Fluxo



$\boldsymbol{B}$

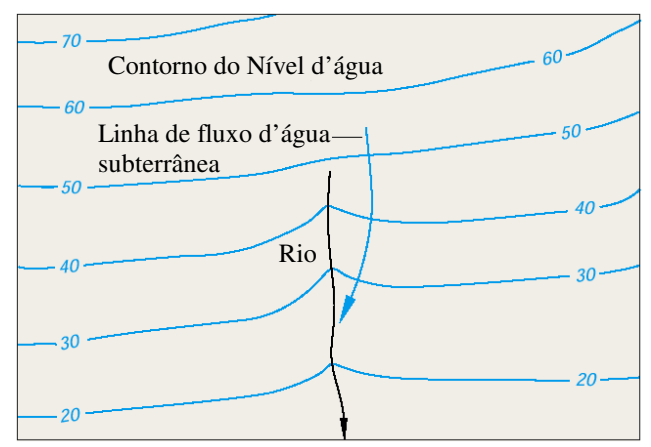

FIGURA 11 - Rio recebendo água do aqǘfero (A). Isto Pode ser determinado pelos mapas dos contornos do nível d'água, pois as linhas de contorno estão em direção contrária ao fluxo onde elas cruzam o rio $(\boldsymbol{B})$.

As FIGURAS 12 a 16 apresentam: Com exceção do caso da FIGURA 15, todos os outros têm o rio em contato hidráulico com a água subterrânea. Nestes casos, a taxa de troca depende da diferença de elevação entre água de superfície e subterrânea próxima ao rio. Quando a posição relativa do nível de água superficial e do nível de água subterrânea na proximidade do rio muda ao longo de seu eixo, o fluxo de troca pode mudar de surgimento para infiltração e vice-versa. Na FIGURA 12 observa-se que a infiltração e o surgimento 
podem acontecer simultaneamente na mesma seção transversal. Caso a direção do fluxo do aqüífero não seja perpendicular ao eixo do rio, o fluxo de troca torna-se tridimensional. Os caminhos dos fluxos tridimensionais ao redor dos rios parcialmente penetrantes são de grande importância para estabelecer caminhos dos fluxos no transporte de materiais contaminantes e no estudo da recarga do aqüífero (BRAINARD e GELHAR, 1991, MEIGS e BAHR, 1995; apud KALERIS, 1998).

Quando o rio está perdendo água ele pode estar conectado ao sistema de água subterrânea por uma zona saturada contínua (FIGURA 16) ou pode estar desconectado ao sistema do aqüífero por uma zona não-saturada. Quando o rio é desconectado do aqüífero por uma zona não-saturada, o nível d'água subterrânea pode ter um pico distinguível abaixo do rio (FIGURA 15), se a taxa de recarga pelo leito e pela zona não-saturada é maior que a taxa lateral do fluxo subterrâneo longe do pico de nível d’água. Uma importante característica dos rios que são desconectados do aquífero é que a extração da água subterrânea rasa perto do rio não afeta o fluxo do rio perto dos poços de bombeamento (WINTER et al., 1998). A configuração do fluxo mostrada na FIGURA 15 também é caracterizada aqui como percolação livre. A taxa de infiltração depende do nível do lençol freático somente se sua superfície influencia a distribuição de umidade na zona não saturada. O nível do lençol no qual o contato hidráulico entre água de superfície e água subterrânea é interrompido, depende fortemente da resistência hidráulica da camada semipermeável no fundo do rio. Tal camada é resultado de processos mecânicos, substâncias químicas e processos biológicos no fundo do rio (BOUWER, 1978, HUISMAN e OLSTHOOM, 1983; apud KALERIS, 1998).

Em alguns ambientes, o ganho ou perda do rio pode ser continuo. Isto é, um rio talvez sempre ganhe água do o aqüífero, ou ele talvez sempre perca água. Entretanto, em outros ambientes, a direção do fluxo pode variar ao longo do rio. Alguns trechos recebem água subterrânea, e outros trechos perdem água para o aqüífero. Além disso, a direção do fluxo pode mudar em um curto espaço de tempo como resultado de tempestades isoladas que 
causam recarga localizada perto da margem, picos de cheia temporários que rebaixam o canal, ou transpiração da água subterrânea através da vegetação lateral ao rio (WINTER et al., 1998).

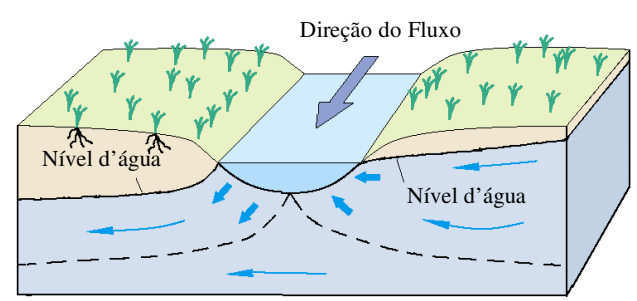

FIGURA 12 - Rio com infiltração e surgimento na mesma seção.

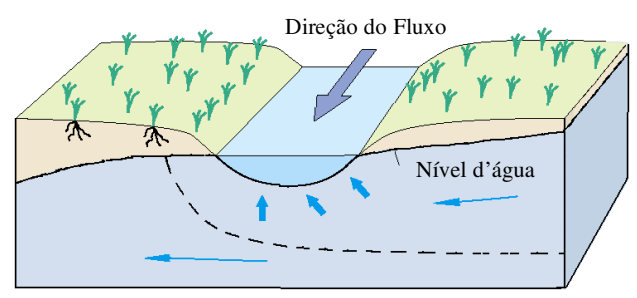

FIGURA 14 - Rio com surgimento apesar de um dos lados ter carga hidráulica menor que o escoamento superficial.

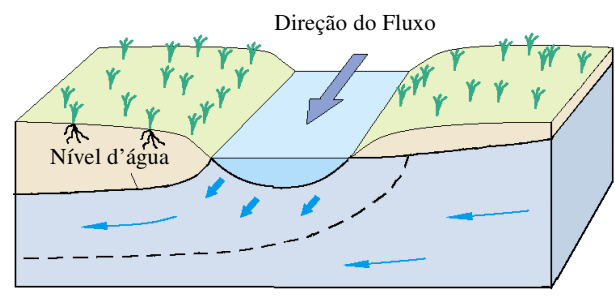

FIGURA 13 - Rio com infiltração apesar de um dos lados ter carga hidráulica maior que $\mathrm{o}$ escoamento superficial.

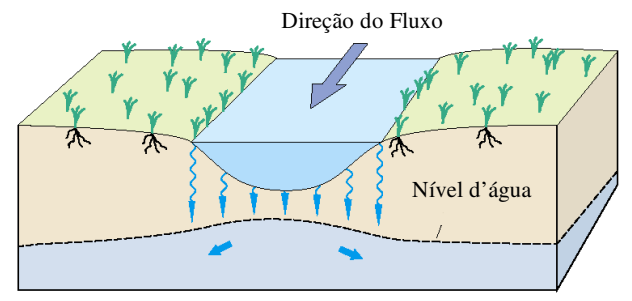

FIGURA 15 - Rios "desconectados" são separados da água subterrânea por uma zona não saturada.

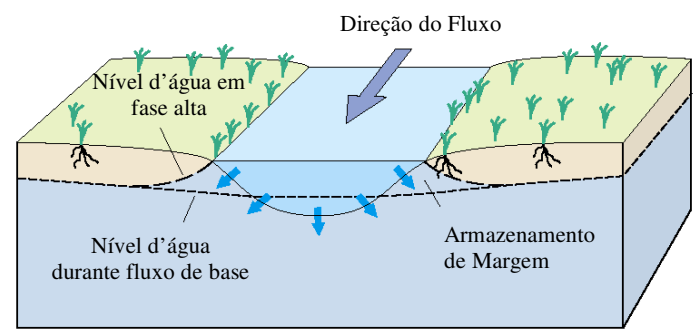

FIGURA 16 - Se os níveis do rio subirem mais alto que os níveis da água subterrânea adjacentes, a água do rio move-se como armazenamento de margem.

Um tipo de interação entre aqüífero e rio, que acontece algumas vezes em quase todos rios, é uma elevação rápida do nível do rio que causa o movimento da água do rio à margem. Este processo, chamado de armazenamento de margem (FIGURAS 16, 17.A e 17.B), normalmente é causado por altas precipitações, rápidos degelos, ou liberação de água de um reservatório a montante. Contanto que a elevação do nível do rio não suba sobre as 
margens, a maior parte do volume de água do rio que entra na margem retorna ao rio dentro de alguns dias ou semanas (WINTER et al., 1998).

A perda de água do rio para o armazenamento de margem e o retorno desta água ao rio em um período de dias ou semanas tende a reduzir o pico de cheia e a atrasar o suplemento de fluxo do rio. Se o estágio de elevação do rio for suficiente para subir sobre as margens e inundar áreas grandes da superfície de terra, a recarga difundida ao aqüífero pode acontecer ao longo da área inundada (FIGURA 17.C). Neste caso, o tempo que leva para a água de inundação recarregada voltar do aqüífero ao rio pode ser de semanas, meses, ou anos, porque os comprimentos do caminho do fluxo da água subterrânea são mais longos que no processo de inundação, sendo o resultado de armazenamento de margem local. Dependendo da frequiência, magnitude, e intensidade da precipitação e a magnitude relatada dos aumentos em fases do rio, alguns rios e aquíferos rasos adjacentes podem estar em um reajustamento contínuo de interações relacionado ao armazenamento e à inundação de margens (WINTER et al., 1998).

Além do armazenamento de margem, outros processos podem afetar a recarga local de água entre rios e aqüíferos rasos adjacentes. Mudanças no fluxo do rio entre as condições de ceder ou receber água também podem ser causadas por bombeamento de água subterrânea perto dos rios. 

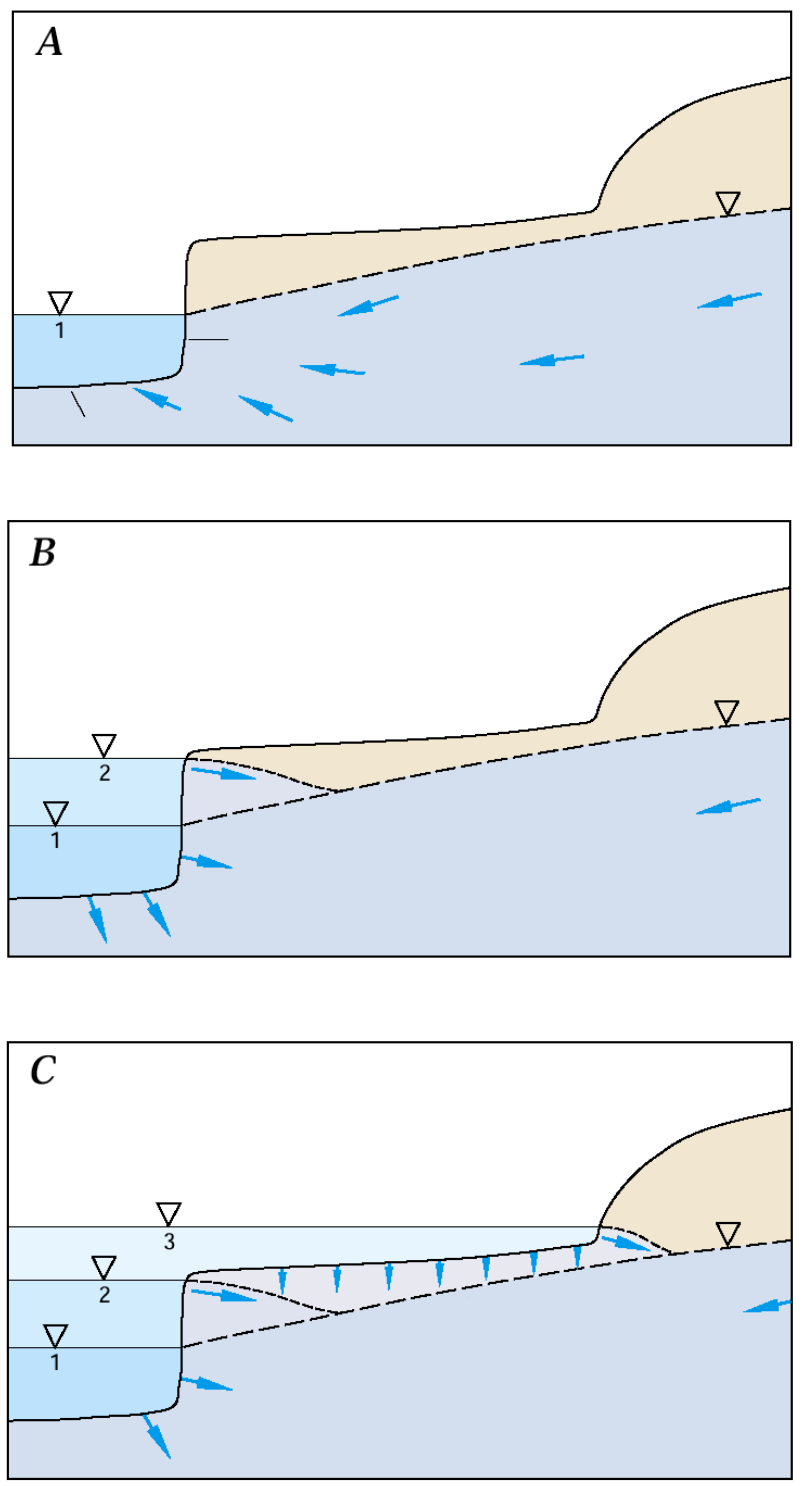

FIGURA 17 - Seqüência do processo de armazenamento de margem. Se a elevação do nível d'água for mais alto que as margens do rio $(\mathrm{C})$, a inundação recarrega o aqüífero ao longo das áreas inundadas.

\subsection{Medidas de Trocas: Rio e Aquíf́ero.}

A quantificação da troca entre um aqüífero subterrâneo e o rio é importante na determinação da recarga e, também, do transporte de contaminantes do rio para o aqǘf́fero. 
Os métodos constantes da literatura conhecidos para quantificação da taxa de troca entre um rio e um aqüífero são os seguintes:

Métodos diretos:

- Infiltrômetros.

- Diferença de Vazões em trechos.

- Lisímetros de fundo de rio.

- Mini-Piezômetros.

Métodos Indiretos:

- Balanço Hídrico.

- Traçadores.

A seguir apresenta-se o resumo de alguns trabalhos dedicados à quantificação da taxa de troca.

As medidas da infiltração são realizadas desde meados de 1940 e foram desenvolvidas devido à necessidade de calcular a quantidade de perdas de canais pela infiltração (ISRAELSON e REEVE, 1944; apud KALERIS, 1998). Essas medidas são usadas hoje no estudo da troca de água superficial e subterrânea (CEY, 1998, WROBLICKY et al., 1998; apud KALERIS, 1998). Um estudo extenso de referências relacionadas à medida da infiltração foi apresentado por CARR e WINTER (1980).

O dispositivo desenvolvido por LEE (1977), de simples construção, teve grande utilização. Um outro dispositivo apropriado para pequenos rios foi apresentado por TRAUB (1982) e KALERIS (1986) (SAEP-infiltrometer). CHEKAUER e MCBRIDE (1988) apresentaram um infiltrômetro para corpos de água com grandes superfícies.

A taxa de troca varia no espaço e no tempo. Variações temporais ocorrem não apenas devido a flutuações do nível de água no rio e no aqüífero, mas também, devido às variações temporais da resistência hidráulica da camada semipermeável do leito (GELDNER, 1980, KALERIS, 1986; apud KALERIS,1998). Discute-se muito, a respeito da 
variação da taxa de troca no espaço, a qual varia tanto com a profundidade da água no rio ou do nível freático em sua proximidade, como, devido à variação da resistência hidráulica da camada colmatada do leito do rio e devido também à variação da condutividade hidráulica do aqüífero, ambos no espaço no qual o rio é inserido.

KALERIS (1998) realizou ensaio com um infiltrômetro produzido pelo SAEP (Agencia Estatal de Proteção Ambiental de Baden - Württemberg na Alemanha) e comparou-o com ensaios com lisímetros no fundo do rio também desenvolvido pelo SAEP. Além disso, ele determinou a taxa de infiltração do rio através da diferença da vazão no inicio e no fim de um trecho do rio em que não havia outras contribuições externas. Concluiu que as medidas da taxa de troca obtidas por infiltrômetro e através da diferença de vazão em um trecho sem contribuição externa apresentam similaridades. Entretanto, tal comparação é válida em condições especiais do trecho do rio.

Com relação à comparação entre o lisímetro e o infiltrômetro, a média da infiltração nos dois métodos foram similares, mas o infiltrômetro pode conter erros quando não se garante que, no fundo do equipamento, não haja entrada de água que não seja subterrânea.

KALERIS (1998), ainda, comenta sobre a utilização de traçadores para determinação da taxa de troca, que segundo CASTRO e HORNBERGER (1991) e HARVEY (1996), têm boa eficácia, dependendo da aplicação do método que requer investimentos elevados.

\subsubsection{A Utilização de Infiltrômetros.}

Métodos para medida da taxa de infiltração no fundo de lagos, estuários e rios foram apresentados por LEE (1977) e LEE e CHERRY(1978). Nesses trabalhos, infiltrômetros construídos com tambores de aço foram muito utilizados como uma forma barata para caracterização da interação entre o aqüífero e o corpo d'água. Esses dispositivos, de simples construção, foram feitos com a parte superior ou com o fundo de tambores (industriais ou de óleo) cortados em uma altura aproximada de $15 \mathrm{~cm}$. Empurrados no fundo do corpo d'água e 
com uma saída onde eram acopladas uma mangueira e uma sacola plástica, tudo completamente vedado para não ocorrer entrada da água do rio (FIGURA 18).

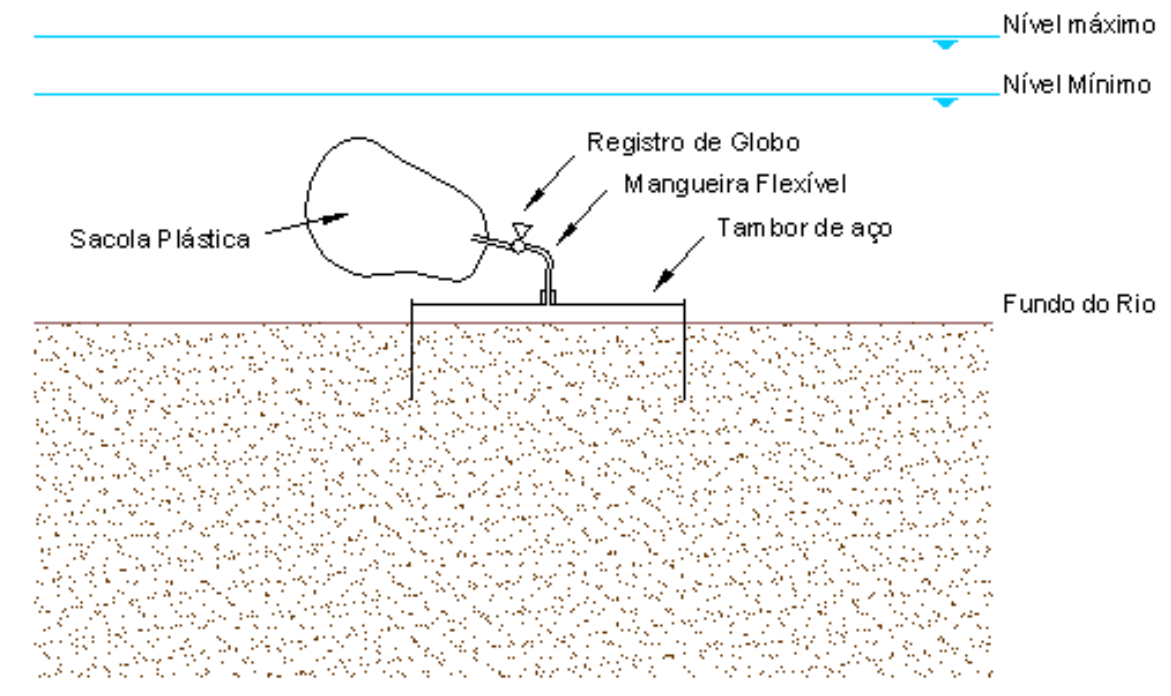

FIGURA 18 - Infiltrômetro similar ao descrito por LEE (1977).

Além desse método há dois outros, nos quais as medidas de infiltração são baseadas: (a) um tubo ou um cilindro sem fundo é fincado no fundo do rio, medindo-se o volume de água necessário para manter o nível de água no tubo igual ao nível de água no rio durante um intervalo definido de tempo, determina-se a infiltração ou surgimento; (b) um cilindro ou um sino ligado a uma sacola plástica é empurrado uma profundidade pequena no fundo do rio. A sacola plástica contém um volume conhecido de água e permanece debaixo da superfície de água no rio durante a medida. A redução do volume de água na bolsa durante o tempo de medição representa a taxa de infiltração. Esse método também pode ser usado em rios com surgimento. Neste caso o volume de água acrescentado à bolsa durante o intervalo de medição representa a taxa de surgimento. Assim, a medida da taxa de troca com sacola plástica pode ser usada em rios com surgimento, como um dispositivo para a determinação da quantidade da água subterrânea que entra no rio. 
A técnica do Infiltrômetro - SAEP utilizado por KALERIS (1998) difere daquele descrito acima, pois consiste de duas partes. A parte mais baixa é composta de um cilindro sem fundo, que é empurrado e permanece no leito do rio. A parte superior, em formato de um sino, é encaixada na parte inferior para realização das medidas de taxa de troca. É adicionada água no equipamento para manter o nível de água igual ao nível do rio para medida da infiltração. A vantagem deste infiltrômetro, segundo KALERIS (1998), é que as medidas sempre são efetuadas na mesma posição, sem perturbar o fundo do rio durante cada medida.

\subsection{Recarga de Aqüífero.}

A recarga natural de um aqüífero pode ser considerada como a quantidade de água, proveniente da precipitação, que alcança a parte saturada do aqüífero e fica disponível por longos períodos de tempo, para aproveitamento. Nesta região, que pode ser entendida como um reservatório, a água normalmente não sofre influência dos processos superficiais, possuindo, entretanto, mobilidade de acordo com as características hidrogeológicas do meio.

Para se estimar a recarga de um aqüífero subterrâneo em uma bacia hidrográfica, é necessário que se faça um balanço hídrico, através da aplicação do conceito de balanço de massa. O balanço hídrico considera o ciclo hidrológico de forma integral, envolvendo a distribuição e o movimento da água em diferentes fases, acima e abaixo da superfície do solo. Através do balanço hídrico, podem-se conhecer as relações entre as fases do ciclo hidrológico e o efeito das ações isoladas sobre algumas destas fases em todo o regime da bacia considerada (UNESCO, 1982 apud POMPÊO, 1990).

CONTIN (1987) realizou trabalhos experimentais para determinação da recarga em uma área de afloramento do aquíf́ero Botucatu (Guarani) na Bacia do Ribeirão da Onça na região de São Carlos no município de Brotas. Para determinação da recarga, foi realizado o balanço hídrico na superfície da bacia, região não saturada e na parte saturada do aquífero 
freático. Foram medidas a precipitação na bacia, a vazão no curso d'água principal e os níveis em poços piezométricos semipenetrantes no aqüífero freático. A escolha da porção saturada do freático, limitada superiormente pelo lençol, foi realizada para minimizar-se o efeito da evapotranspiração, da qual não se dispunham de medidas.

O balanço efetuado na parte saturada, no período de estiagem, forneceu uma avaliação para a recarga do aqǘf́ero Botucatu (Guarani). Os resultados dessa avaliação foram estendidos para o período úmido, servindo de previsão para o balanço na parte não saturada do aqüífero superior. O escoamento direto foi obtido por análise do hidrograma do rio e conseqüente separação do escoamento básico. A infiltração na superfície foi determinada subtraindo-se da precipitação a parcela que atinge o curso d'água.

A análise do comportamento das grandezas medidas permitiu um melhor entendimento do escoamento que se verifica no aqüífero freático, bem como o efeito da condição do contorno na interação entre aqüífero e rio. Com essa metodologia, CONTIN (1987) realizou o estudo do ciclo hidrológico da bacia de modo a separar e avaliar quantitativamente quase todas as grandezas relevantes que o compõe. Assim foram obtidos os seguintes resultados:

- o escoamento direto na região de afloramento era insignificante.

- do total infiltrado, $80 \%$ se constitui em variação da umidade do solo e evapotranspiração.

- a recarga do aqüífero freático apresenta forte correlação com a precipitação, crescendo de $9 \%$ no início do período úmido para até $20 \%$ ao final das chuvas.

- considerando-se a soma (variação no armazenamento no aqüífero freático mais recarga do aqǘf́ro freático) a recarga do Botucatu representa cerca de 40\% desse total.

Na conclusão desse trabalho, CONTIN (1987) comenta que a metodologia por ele proposta, acrescida das hipóteses que foram assumidas, foi capaz de identificar e quantificar todas as grandezas físicas relevantes que intervêm no balanço hídrico da porção da bacia 
considerada. No entanto, ele verificou a necessidade de continuação deste estudo do balanço incorporando informações relativas a evapotranspiração, transferência entre bacias e Represa do Lobo e interação entre aqǘf́ero e rio para que se possa prescindir das diversas hipóteses simplificadoras adotadas e obter compreensão dos resultados para toda a bacia.

POMPÊO (1990) desenvolveu um trabalho para o estudo hidrológico do balanço hídrico da zona não saturada na Bacia do Ribeirão da Onça. Neste estudo, durante dois anos, realizou medidas, além das precipitações diárias e da vazão no curso d'água, de outras variáveis hidroclimatológicas que possibilitaram estimativas da evapotranspiração. As variações da umidade no solo, em 14 pontos da bacia, com profundidades até $11 \mathrm{~m}$, foram monitoradas por meio de sondas de nêutrons. O autor apresentou uma Síntese Bibliográfica ampla referente ao estudo da recarga subterrânea, apresentando definições e detalhando métodos para determinação ou estimativa das componentes hidrológicas para a execução do balanço hídrico. Ressalta que normalmente existem duas camadas diferenciadas na zona nãosaturada, sendo a camada superior às zonas das raízes onde ocorrem processos fisiológicos causados pela presença da vegetação. Logo abaixo existe uma camada em que o movimento da água sofre consequiências dos processos físicos sob ação das forças gravitacional, de fricção e matricial. As recargas determinadas respectivamente nessas duas camadas são chamadas de recarga potencial e recarga real. Para determinação do balanço hídrico na zona não-saturada, é necessário que se determinem as propriedades do meio, sendo estas: o conteúdo de umidade, o potencial matricial e a condutividade hidráulica, que, interrelacionados, tornam suas características bastante complexas.

Segundo POMPÊO (1990), as principais técnicas para estimativa da recarga foram desenvolvidas na hidrologia clássica. O balanço hídrico, representado pela equação da conservação de massa, a longo prazo, pode oferecer alguma aproximação de volume de recarga subterrânea, mas para a aplicação dessa equação existem muitas dificuldades devido aos problemas na determinação de suas componentes que possuem variabilidade muito grande e são de difícil medição. Assim, diversos procedimentos têm sido utilizados para 
obtenção da recarga, pautando-se por tentar simplificar a representação dos processos e, quando possível, reduzir o volume de informações necessárias. Finalizando seu trabalho, POMPÊO (1990) apresenta algumas conclusões e sugestões, onde ele descreve alguns comportamentos não esperados no estudo do ciclo hidrológicos e no uso da sonda de nêutrons e sugere uma continuação utilizando uma combinação de métodos para aprimorar o estudo da recarga do aqüífero.

\subsection{Flutuação do Nível D’água em Aqüíferos.}

Medidas das flutuações do nível d'água em piezômetros ou em poços de observação são recursos importantes em muitos estudos de águas subterrâneas. Essas flutuações em aqüíferos podem ser resultado de uma grande variedade de fenômenos hidrológicos, naturais ou induzidos pelo homem. Em muitos casos, pode haver mais que um mecanismo simultâneo, e para as medidas serem interpretadas corretamente, é importante conhecer os vários fenômenos. A TABELA 01 apresenta um resumo destes mecanismos, classificando se eles são naturais ou induzidos pelo homem, se eles produzem flutuações em aqüíferos confinados ou freáticos e se eles são de vida curta, a longo prazo, diários ou sazonais. Também se nota que alguns dos mecanismos operam sobre influências climáticas, enquanto outros não.

Mudanças na pressão atmosférica podem produzir flutuações relativamente grandes em poços de observação ou piezômetros em aqüíferos confinados (dezenas de sentimentos). A relação é inversa; aumentos na pressão atmosférica criam rebaixamento no nível de água observado (FREEZE e CHERRY, 1979). JACOB (1940) invocou o princípio de tensão efetiva para explicar o fenômeno da flutuação dos níveis d'água em aqüífero confinado. 
TABELA 01 - Sumário dos Mecanismos que Conduzem à Flutuação do Nível de Água Subterrânea

(Freeze e Cherry, 1979).

\begin{tabular}{|c|c|c|c|c|c|c|c|c|c|}
\hline & Freático & Confinado & Natural & $\begin{array}{c}\text { Influência } \\
\text { do } \\
\text { Homem }\end{array}$ & $\begin{array}{l}\text { Vida } \\
\text { curta }\end{array}$ & Diário & Sazonal & $\begin{array}{l}\text { Longo } \\
\text { prazo }\end{array}$ & $\begin{array}{l}\text { Influência } \\
\text { climática }\end{array}$ \\
\hline $\begin{array}{l}\text { Recarga de Aqüífero. } \\
\text { (Infiltração no Subsolo) }\end{array}$ & $\sqrt{ }$ & & $\sqrt{ }$ & & & & $\sqrt{ }$ & & $\sqrt{ }$ \\
\hline $\begin{array}{l}\text { Armadilha de Ar durante } \\
\text { Recarga de Aqüífero. }\end{array}$ & $\sqrt{ }$ & & $\sqrt{ }$ & & $\sqrt{ }$ & & & & $\sqrt{ }$ \\
\hline $\begin{array}{l}\text { Evapotranspiração e } \\
\text { Consumo Freático }\end{array}$ & $\sqrt{ }$ & & $\sqrt{ }$ & & & $\sqrt{ }$ & & & $\sqrt{ }$ \\
\hline $\begin{array}{l}\text { Efeito do Armazenamento } \\
\text { de Margem Perto do Rio }\end{array}$ & $\sqrt{ }$ & & $\sqrt{ }$ & & & & $\sqrt{ }$ & & $\sqrt{ }$ \\
\hline $\begin{array}{c}\text { Efeito da Maré } \\
\text { perto dos oceanos }\end{array}$ & $\sqrt{ }$ & $\sqrt{ }$ & $\sqrt{ }$ & & & $\sqrt{ }$ & & & \\
\hline $\begin{array}{l}\text { Efeito da Pressão } \\
\text { Atmosférica. }\end{array}$ & $\sqrt{ }$ & $\sqrt{ }$ & $\sqrt{ }$ & & & $\sqrt{ }$ & & & $\sqrt{ }$ \\
\hline $\begin{array}{l}\text { Carregamento Externo } \\
\text { de Aqüífero Freático }\end{array}$ & & $\sqrt{ }$ & & $\sqrt{ }$ & $\sqrt{ }$ & & & & \\
\hline Terremotos & & $\sqrt{ }$ & $\sqrt{ }$ & & $\sqrt{ }$ & & & & \\
\hline $\begin{array}{c}\text { Bombeamento de Água } \\
\text { Subterrânea. }\end{array}$ & $\sqrt{ }$ & $\sqrt{ }$ & & $\sqrt{ }$ & & & & $\sqrt{ }$ & \\
\hline $\begin{array}{l}\text { Poço de Injeção } \\
\text { Profundo }\end{array}$ & & $\sqrt{ }$ & & $\sqrt{ }$ & & & & $\sqrt{ }$ & \\
\hline $\begin{array}{c}\text { Recarga Artificial: } \\
\text { Perdas em Reservatórios, } \\
\text { Lagoas, e Aterros. }\end{array}$ & $\sqrt{ }$ & & & $\sqrt{ }$ & & & & $\sqrt{ }$ & \\
\hline $\begin{array}{l}\text { Irrigação e Drenagem } \\
\text { Agrícola. }\end{array}$ & $\sqrt{ }$ & & & $\sqrt{ }$ & & & & $\sqrt{ }$ & $\sqrt{ }$ \\
\hline $\begin{array}{l}\text { Drenagem de Geotécnica: } \\
\text { de minas a céu aberto, } \\
\text { taludes, túneis, etc. }\end{array}$ & $\sqrt{ }$ & & & $\sqrt{ }$ & & & & $\sqrt{ }$ & \\
\hline
\end{tabular}

Também tem sido observado que mudanças na pressão atmosférica podem causar pequena flutuação do nível d'água em aquíferos freáticos (1 a 6 cm). À medida que aumenta a pressão do ar, o nível d'água no aquífero é rebaixado. PECK (1960) relaciona os efeitos das mudanças de pressões no ar aprisionado na zona não saturada do solo às flutuações do nível d'água. À medida que aumenta a pressão, o ar ocupa menos espaço, ocorre o decréscimo do nível d'água. TURK (1975) mediu uma flutuação diária de até $6 \mathrm{~cm}$ em um aqüífero com uma granulometria bem-graduada e com nível d'água raso. HARE e MORSE (1997) também observaram a variação do nível d'água em um aqüífero freático. Eles isolaram uma porção do aqüífero através de uma parede impermeável e de uma cobertura com argila. Comparou-se então a variação do nível na porção isolada com um poço livre e verificou-se que o isolamento proporciona um maior efeito da variação da pressão atmosférica. 
YORK et al. (2002) estudaram a interação entre o aqüífero e a atmosfera em uma bacia a nordeste de Kansas nos Estados Unidos da América. Segundo eles, este estudo pode ser importante em regiões onde o nível d'água é raso $(<2 \mathrm{~m})$, pois proximidade da água ao solo e à vegetação provê água à evapotranspiração. Um modelo acoplando o aqüífero e sua superfície atmosférica foi desenvolvido para estudar a interação entre a atmosfera e o aqüífero em bacias hidrográficas, ao longo de décadas. Esse modelo mostrou que anualmente de 5 a $20 \%$ das águas subterrâneas sustenta a evapotranspiração, para a região estudada. A fração da evapotranspiração sustentada pelo aquífero é maior nos anos secos, quando a evapotranspiração excede a precipitação.

TANCO e KRUSE (2001) estudaram a flutuação do nível d'água na província de La Pampa na Argentina. Uma relação entre precipitação e flutuações do nível d'água e uma metodologia para a previsão dessa flutuação foi desenvolvida. Uma boa comparação entre as flutuações do nível d'água observadas e previstas foi verificada ao calcular as flutuações do nível nas estações de verão e de outono.

Tendo em vista as variações nos níveis de água no lençol freático, em respostas às variações na pressão atmosférica, espera-se que haja influência destas sobre a interação rioaqüífero especificamente no que diz respeito às taxas de troca no fundo de rios. Entretanto, não se localizou na literatura nenhum estudo sobre os efeitos da variação na pressão atmosférica sobre as trocas no fundo de rio. 


\section{MATERIAIS E MÉTODOS.}

O estudo da taxa de troca entre o aqǘf́ero e o rio foi realizado no Ribeirão da Onça, localizado no município de Brotas nas proximidades do CRHEA - USP (Centro de Recursos Hídricos e Ecologia Aplicada da Universidade de São Paulo). Este Centro possui profissionais experientes em trabalhos hidrológicos, além, de toda infra-estrutura necessária para pesquisas na área de Recursos Hídricos.

\subsection{Descrição do Aqüífero Guarani.}

O sistema Aqüífero Guarani é formado principalmente pela Formação Botucatu que é constituída por arenito com grãos arredondados bem selecionados, originados no jurássico superior. É composto por formações de fácies eólica, fácies eólico-fluvial e fácies estritamente lacustre-fluvial, sendo esta última denominada antigamente de Formação Pirambóia. O aqüífero Guarani é importante por representar cerca de $80 \%$ do potencial hidrogeológico da Bacia do Paraná.

A área do Aqüífero Guarani é aproximadamente de $1.300 .000 \mathrm{~km}^{2}$, com condutividade da ordem de $10^{-5} \mathrm{~m} / \mathrm{s}$, estendendo-se, em território brasileiro, pelos Estados de Goiás, Mato Grosso, Mato Grosso do Sul, Minas Gerais, São Paulo, Paraná, Santa Catarina e Rio Grande do Sul, avançando ainda ao leste do Paraguai, ao noroeste do Uruguai e ao nordeste da Argentina. O aqüífero sofre confinamento por basalto de Formação Serra Geral em aproximadamente $90 \%$ de sua extensão. A região exposta, onde o aqüífero é de superfície livre, corresponde a aproximadamente $150.000 \mathrm{~km}^{2}$, distribuindo-se em faixas 
estreitas dispostas longitudinalmente à escarpa da Formação Serra Geral (DE LOCZY,1966; apud POMPÊO, 1990). A FIGURA 19 mostra a localização das faixas de afloramento do Aqüífero Guarani, destacando, no Estado de São Paulo, a região de São Carlos, próximo à região em estudo.

O sistema Aqüífero Guarani mergulha em direção ao centro da Bacia do Paraná, apresentando espessura média da ordem de 300 a 400 m, chegando a 834 m nas regiões mais profundas.

Acredita-se que a alimentação do Aqǘfero Guarani ocorre, principalmente, por infiltração direta das chuvas nas zonas de afloramento. As Formações Serra Geral e BauruCaiuá podem, ocasionalmente, fornecer alimentação indireta, comportando-se como reservatórios intermediários que, ao atingirem a saturação, oferecem condições de migração das águas através de descontinuidades relativamente permeáveis. Entretanto, nas regiões onde os níveis piezométricos do Aqüífero Guarani são superiores aos de seus aqüíferos sobrepostos ocorre fluxo ascendente. A descarga natural do Aqüífero Guarani se faz em algumas regiões dos Estados de Santa Catarina e Rio Grande do Sul, havendo provavelmente outra região de descarga ao nordeste da Argentina conforme assinalado por (GILBOA, 1976; apud POMPÊO, 1990). 


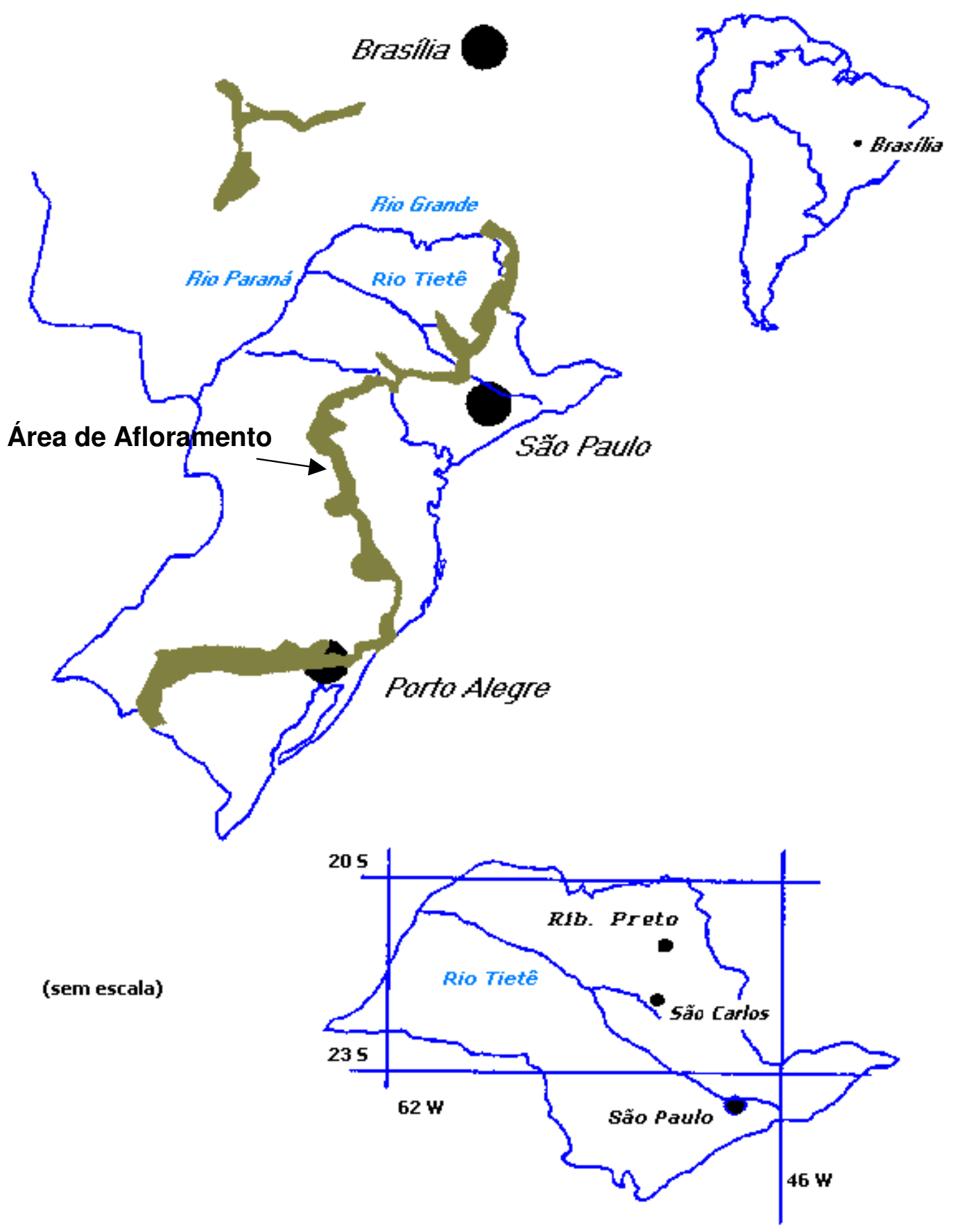

FIGURA 19 - Localização dos Afloramentos do Aquífero Guarani em território brasileiro. 


\subsection{A Bacia do Ribeirão da Onça.}

\subsubsection{Localização.}

A bacia do Ribeirão da Onça localiza-se na região do Município de Brotas, ao centro-norte do Estado de São Paulo entre os paralelos $22^{\circ} 10^{\prime}$ e $22^{\circ} 15^{\prime}$ de latitude sul e entre os meridianos $47^{\circ} 55^{\prime}$ e $48^{\circ} 00^{\prime}$ de longitude oeste. O Ribeirão da Onça é um dos formadores do Rio Jacaré-Guaçu, afluente do Rio Tietê pela margem direita (FIGURA 20).

A Bacia do Ribeirão da Onça não tem proteção ambiental garantida por legislação, apesar de fazer parte do afloramento do Aqüífero Guarani e de situar-se próxima a uma área de Proteção Ambiental (APA) bem mais ampla que engloba o Ribeirão do Lobo, Represa do Broa e o Córrego do Feijão, este responsável por parte do abastecimento urbano da cidade de São Carlos. 


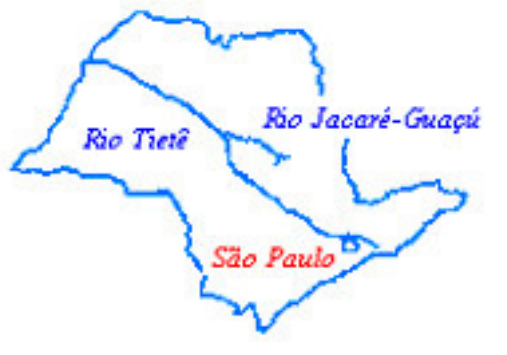

Bacia do Rio Jacaré-Guaçú


FIGURA 20 - Localização da Bacia do Ribeirão da Onça. 


\subsubsection{Características Físicas.}

A caracterização fisiográfica da Bacia do Ribeirão da Onça foi elaborada por (MATTOS, 1984, PRETO FILHO, 1985; apud POMPÊO, 1990) sobre mapas em escala 1:10.000, sendo obtidos os elementos abaixo apresentados:

- $\quad$ área de drenagem

- perímetro

- comprimento axial

- $\quad$ extensão do curso d'água principal

- comprimento total dos cursos d'água

- $\quad$ altitude máxima

- $\quad$ altitude mínima

$$
\begin{array}{r}
65,50 \mathrm{~km}^{2} \\
42,09 \mathrm{~km} \\
11,50 \mathrm{~km} \\
16,00 \mathrm{~km} \\
55,66 \mathrm{~km} \\
840 \mathrm{~m} \\
640 \mathrm{~m}
\end{array}
$$

Três seções do eixo principal do Ribeirão da Onça foram escolhidas para a experimentação de campo. Na FIGURA 21 apresenta-se a localização dessas seções e a representação das áreas de drenagem.

As áreas são as seguintes:

Seção $1=>53,45 \mathrm{~km}^{2}$.

Seção $2=>52,78 \mathrm{~km}^{2}$

Seção $3=>46,18 \mathrm{~km}^{2}$ 




Seção 1 Seção 2 Seção 3

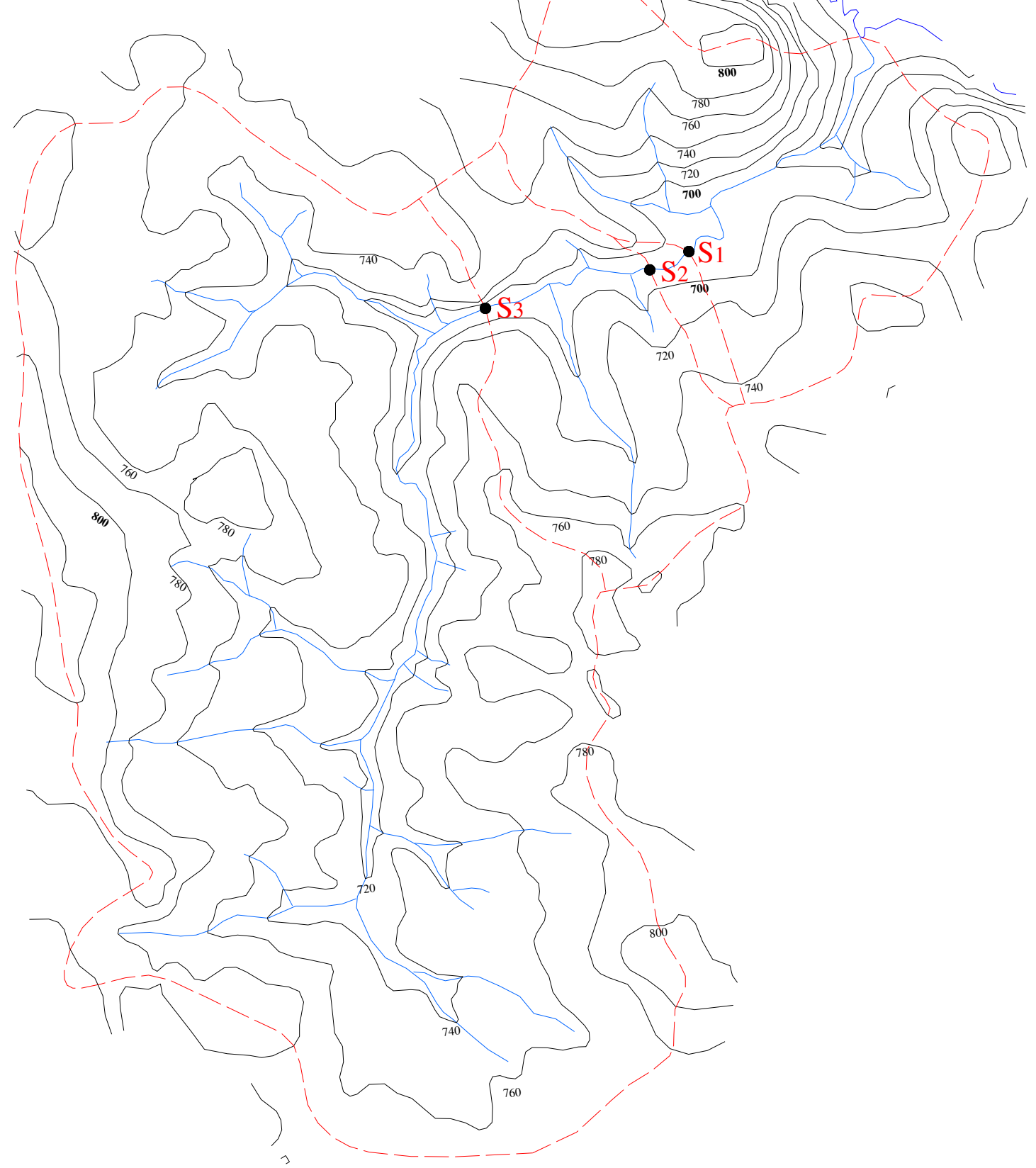

FIGURA 21 - Planta Topográfica da Bacia do Ribeirão da Onça com Seções 1, 2 e 3. 
A FIGURA 22 apresenta fotos do Ribeirão da Onça em uma das seções de estudo. Verifica-se nestas fotos que a falta de uma mata ciliar causa o aparecimento de grandes erosões e voçorocas, que aumentam o transporte de sedimentos causando problemas de perda de solo e assoreamentos.
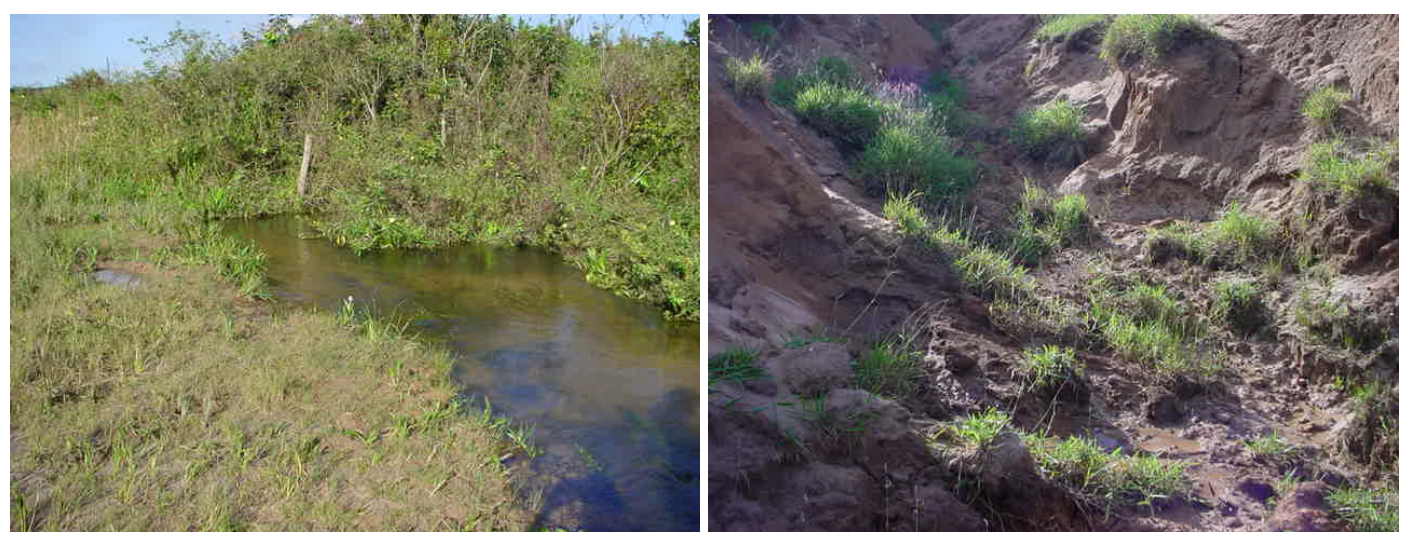

FIGURA 22 - Fotos do Ribeirão da Onça na seção 3.

\subsubsection{Dados Hidrometeorológicos.}

Os dados de pressão atmosférica e precipitação foram obtidos da Estação Climatológica do Centro de Recursos Hídricos e Ecologia Aplicada (CRHEA) da USP, que se localiza próxima à bacia em estudo.

A Estação Climatológica instalada no CRHEA está capacitada a efetuar as medidas meteorológicas de interesse para o programa e monitoramento climatológico da região. Informações sobre precipitação, vento, umidade relativa, evaporação, radiação solar, pressão atmosférica são compiladas todos os anos, e constituem um importante acervo da estação.

\subsubsection{Fluviometria.}

As vazões, na seção 2 do Ribeirão da Onça, foram obtidas através da medida do nível d'água e a construção de uma curva chave utilizando um molinete. No total, foram 
realizadas cinco medidas de vazão. Conforme observado por CONTIN (1987), a seção apresentou uma contínua evolução do formato da calha. Essa variação pode ser visualizada na FIGURA 23.

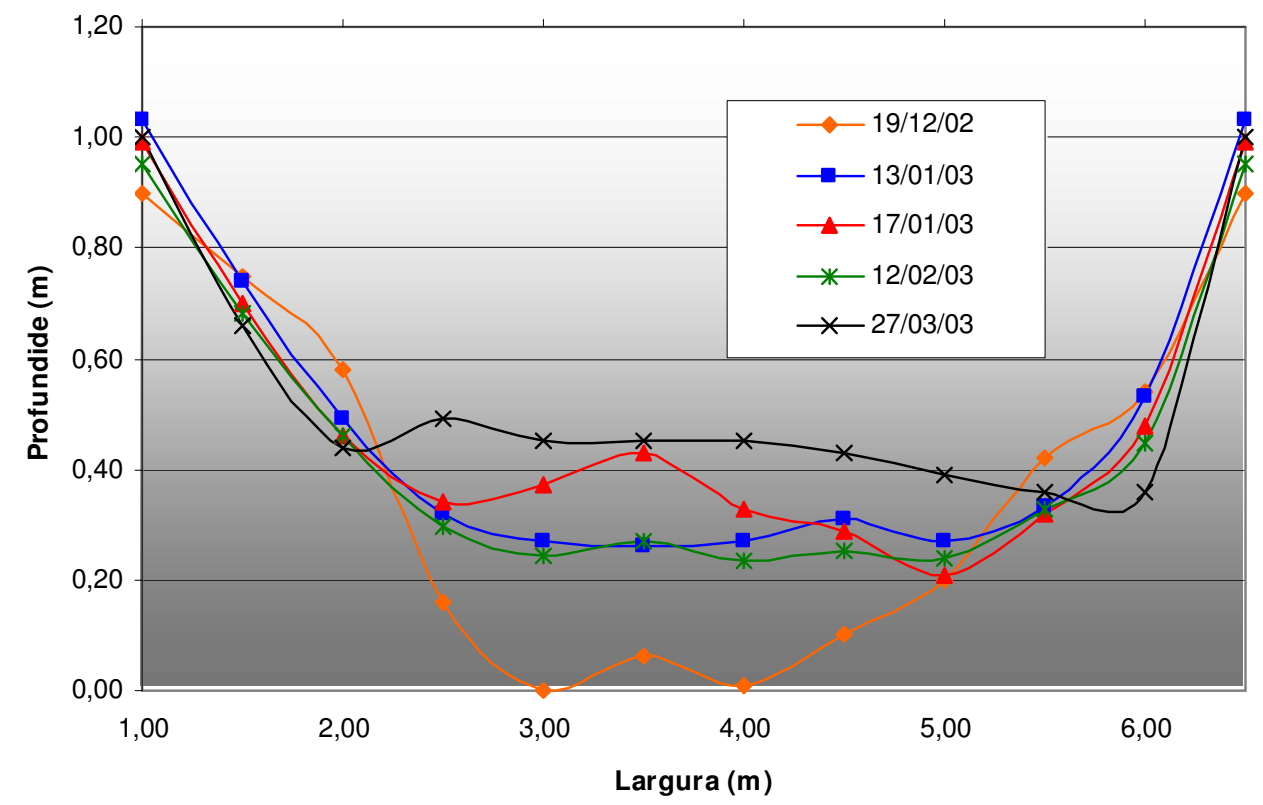

FIGURA 23 - Evolução do Formato da calha.

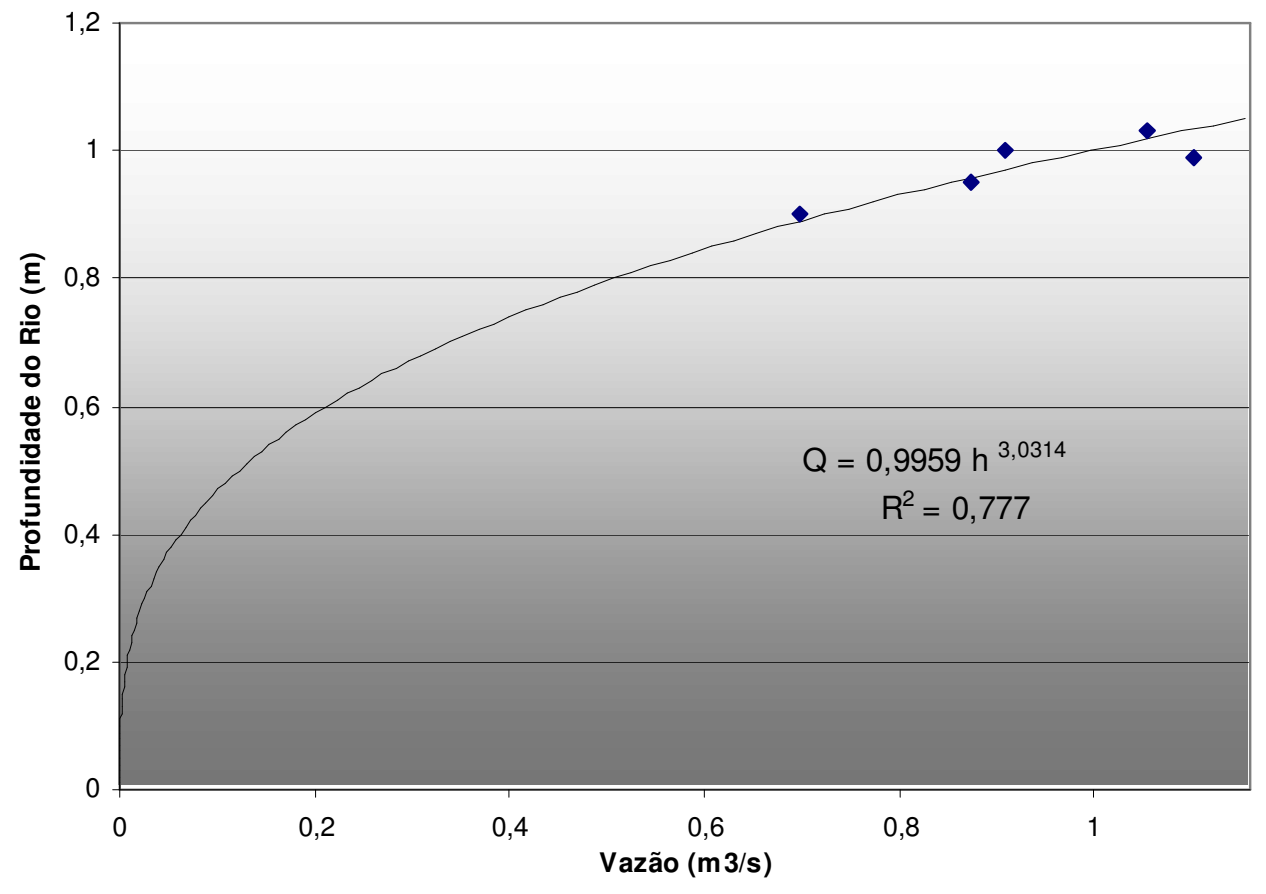

FIGURA 24 - Curva-Chave. 
A partir das vazões observadas, uma equação do tipo $Q=a h^{b}$, foi ajustada com $a=0,996$ e $b=3,03$ (FIGURA 24).

\subsection{Descrição dos Infiltrômetros.}

\subsubsection{Emprego de Infiltrômetros.}

Com base no estudo de equipamentos para a finalidade de medida de trocas no fundo do Ribeirão da Onça, decidiu-se construir um equipamento simples (FIGURA 18) como o apresentado por LEE (1977). A instalação deste infiltrômetro requer cuidados especiais para evitar perturbação excessiva do material de fundo do rio e, ainda, assegurar um contato perfeito entre o cilindro inferior e o fundo.

O tipo de interação (infiltração ou surgimento) entre o lençol freático e o Ribeirão da Onça foi caracterizado realizando-se medidas da interação ao longo do canal principal, para as quais, três locais foram escolhidos.

Muitas dificuldades foram encontradas no emprego dos infiltrômetros, principalmente devido ao leito arenoso que estava em constante movimento e algumas vezes descalçava o tambor impossibilitando os ensaios. Um outro problema encontrado foi que, em regiões onde o fundo do rio possuía alguma matéria orgânica, o tambor não podia ser colocado, pois, acumulavam-se gases que impediam o fluxo normal da água.

Foram confeccionados e empregados três infiltrômetros para assegurar medidas simultâneas nas três seções escolhidas. Antes de levar ao campo, foram feitos ensaios em laboratório para verificação da estanqueidade do equipamento e das sacolas plásticas. Foram encontradas algumas dificuldades na construção dos infiltrômetros. Esses problemas serão descritos mais adiante.

Para melhor caracterizar o tipo de interação, medidas mais detalhadas da superfície freática foram feitas com auxilio de poços de observação. 


\subsubsection{Experimentos de Campo - Primeira Etapa.}

Durante aproximadamente dois meses, por meio de 30 visitas ao campo, tentou-se quantificar a interação rio aquíffero nas três seções de estudos do Ribeirão da Onça.

Os ensaios de campos da primeira etapa para quantificação da interação rio-aqüífero, consistiram em:

- Corte dos tambores a uma altura de $25 \mathrm{~cm}$, perfuração e fixação de um espigão, na parte superior, para acoplamento de uma mangueira, um tratamento anti-ferrugem e pintura (FIGURA 25).

- Preparação das sacolas de plástico - soldagem de lâminas, acoplamento do tubo, colocação do registro, enchimento com água e retirada do ar e pesagem prévia (FIGURA 26).

- Colocação dos tambores no leito do rio nos três pontos escolhidos (somente no primeiro dia).

- Acoplamento da sacola plástica e abertura do registro.

- Retirada do conjunto sacola-registro no dia posterior, após o fechamento da registro.

- Pesagem do conjunto sacola-registro encontrando-se a variação do volume durante o dia de ensaio. 


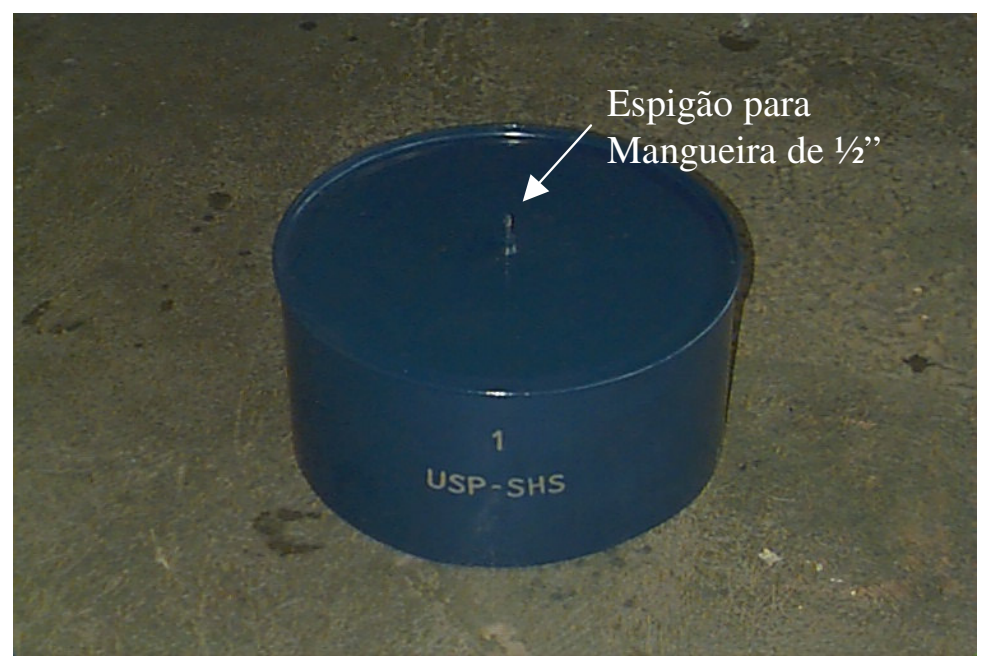

FIGURA 25 - Tambor cortado, com espigão, pintado e identificado.

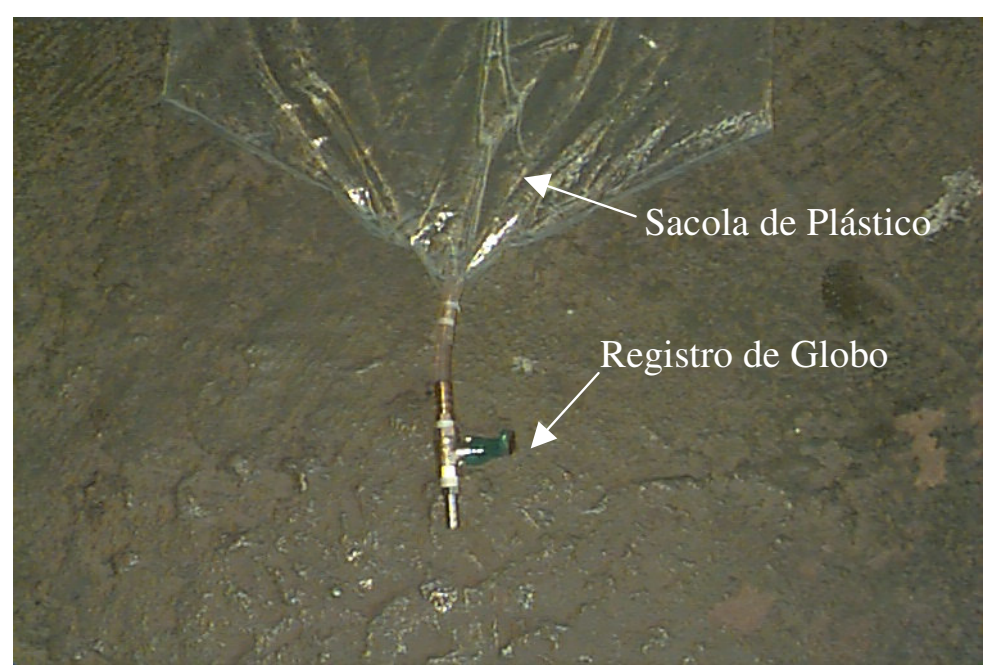

FIGURA 26 - Sacola de plástico soldada e fixada à mangueira com registro.

Como não se conhecia, com certeza, o valor da interação ocorrida durante as 24 horas, esses primeiros testes serviam para conhecer a ordem de grandeza da interação.

Apesar de muita insistência, sempre tentando resolver os problemas que ocorriam a cada ensaio, os resultados encontrados nessa primeira etapa não eram confiáveis. Entre os problemas encontrados tivemos:

- Dificuldade em garantir a vedação das sacolas plásticas, que perfuravam devido ao manuseio e à fragilidade do material. 
- Apesar de que, em todas as visitas ao campo, eram levadas duas ou três sacolas extras, algumas vezes a maioria inutilizava-se durante o transporte, e não se garantiam os ensaios nos três pontos do rio.

- Muitas sacolas perfuravam durante o transporte de volta ao laboratório, também impossibilitando estas medições.

- Em algumas ocasiões, os tambores eram arrastados pela correnteza, pois os sedimentos em torno do tambor eram erodidos, e sua fixação no fundo era prejudicada.

- Logo após a colocação ou recolocação do tambor no leito do rio, muitas vezes, o valor da interação era praticamente nulo ou negativo. Esses valores não podem ser considerados corretos, pois o lençol freático aflorava nas duas margens da seção. Com a retirada desses tambores, verificou-se a existência de ar dentro deles que, apesar dos cuidados tomados na colocação, tornavam a aparecer. Isso pode ser devido à presença de gases, resultado da decomposição orgânica do material existente no leito do rio.

- O diâmetro de saída dos infiltrômetros era pequeno e seu entupimento ocorria devido à presença da sujeira no fundo do rio.

Devido aos problemas enumerados acima, decidiu-se reconstruir os equipamentos utilizados, tentando melhorar a estanqueidade da sacola e facilitar o fluxo de saída do tambor apesar da presença de gases. Além disso, decidiu-se proteger a sacola plástica colocando-a numa caixa de apoio adequada. 


\subsubsection{Reconstrução dos Infiltrômetros.}

Nesta segunda etapa, construíram-se três infiltrômetros, sendo dois utilizando tambores de 200 litros e um utilizando uma lata de óleo de 20 litros. No tambor maior foram providenciados os cortes das extremidades na oficina mecânica central da Escola de Engenharia de São Carlos. Além disso, foi soldado um espigão de $3 / 4$ " com saída para mangueira $3 / 4$ " na lateral do tambor, diferindo do equipamento anterior em que a saída principal era na parte superior do tambor. Essa saída lateral dificulta o dobramento da mangueira, fato, que anteriormente prejudicava os ensaios. Um espigão de $1 / 2$ " com saída $3 / 8$ " para mangueira foi soldado no centro superior do tambor, semelhante aos infiltrômetros anteriores, mas a função dessa saída agora é para a retirada de ar.

Para controle da ferrugem, assim como nos infiltrômetros da etapa anterior, foi realizado um tratamento com um produto anti-ferrugem e providenciado a pintura dos tambores (Figuras 27 e 28).

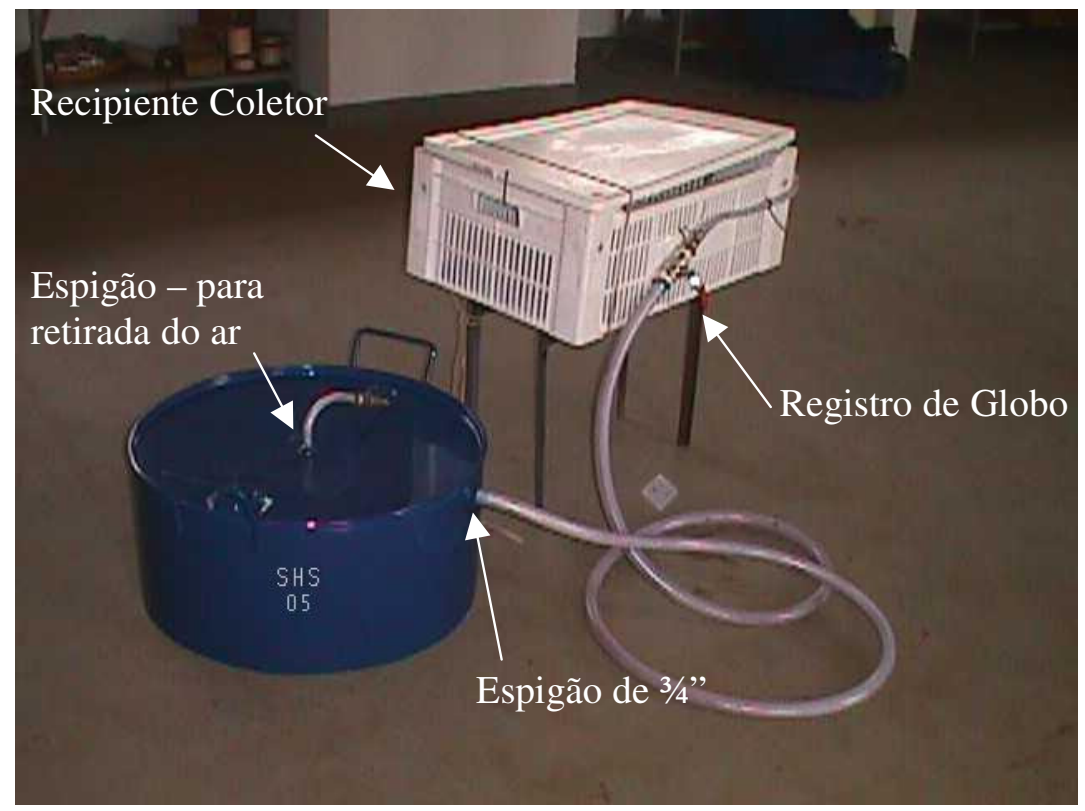

FIGURA 27 - Infiltrômetro e Recipiente Coletor. 
Os ensaios realizados na segunda fase constituíram dos seguintes procedimentos.

- Colocação do tambor com uma mangueira de diâmetro $3 / 4$ " com comprimento de aproximadamente 3 metros no leito do rio, tomando cuidados para que todo o ar fosse retirado (primeiro dia).

- Abertura do registro da saída superior do tambor para retirada do ar (primeiro dia).

- Espera de aproximadamente 10 minutos para estabilização da pressão no interior do tambor antes da colocação da sacola (primeiro dia).

- Acoplamento do conjunto (recipiente plástico, vasilhame, mangueira e registro), já previamente pesado e sem ar.

- Abertura do registro do conjunto.

- Espera de 1 hora.

- Retirada do conjunto.

- Pesagem do conjunto no laboratório.

A diferença entre o valor dos pesos antes e depois do ensaio de campo é o valor da interação rio-aqüífero daquela hora. Assim, em torno de três vezes por semana foram realizados esses ensaios.

Nivel máximo

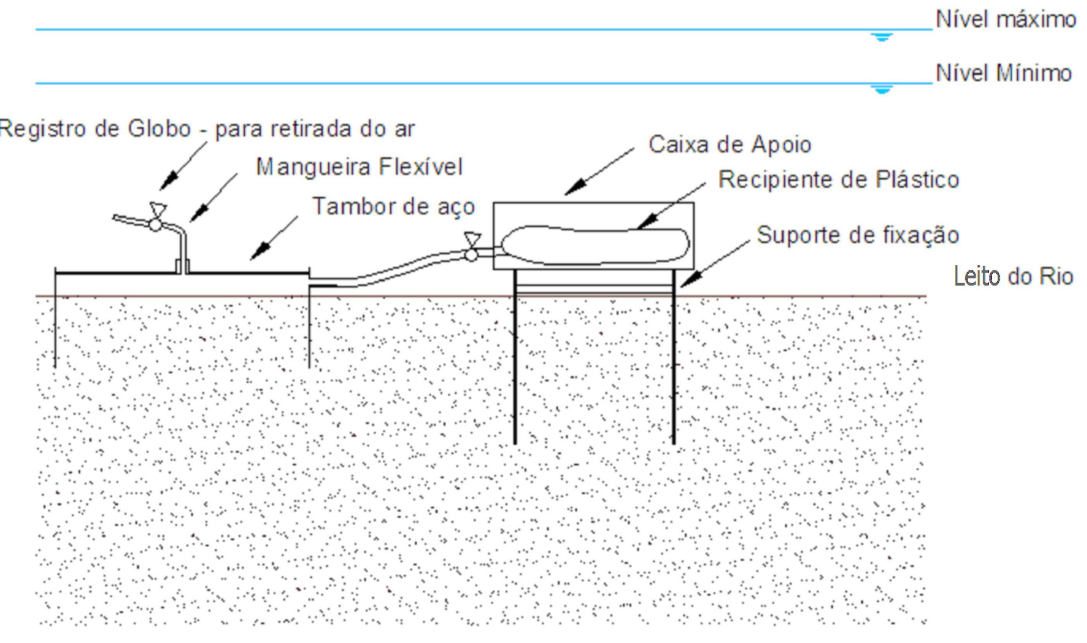

FIGURA 28 - Representação do Infiltrômetro Reconstruído. 


\subsubsection{Coletores de Surgimento Aprimorados.}

Devido aos problemas encontrados com as sacolas de plástico utilizadas na primeira fase, buscou-se uma nova alternativa. Adquiriu-se de uma loja de equipamentos médicos, um travesseiro de água quente em PVC flexível de 60 x $40 \mathrm{~cm}$ e decidiu-se testá-lo para utilização como recipiente plástico d'água nesta pesquisa. No bocal de enchimento desse recipiente plástico acoplou-se uma mangueira de $1 \frac{1}{2}$, vedando-se com uma cola. Para uma melhor proteção do recipiente plástico, utilizou-se uma caixa de apoio tipo "engradado" com uma tampa (FIGURA 29-a e 29-b) .

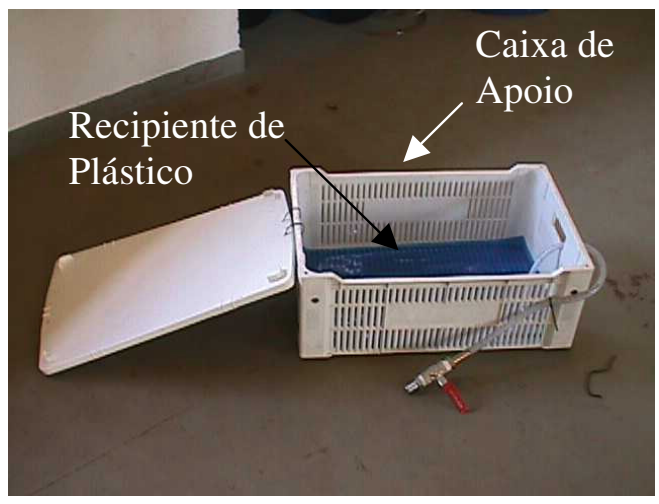

(a)



(b)

FIGURA 29 - (a) Caixa de apoio para proteção do recipiente de plástico. (b) Acoplamento da mangueira ao bocal do recipiente plástico.

\subsubsection{Testes com o Equipamento Aprimorado e o Recipiente plástico.}

\subsubsection{Testes Realizados.}

Realizaram-se testes no Laboratório de Hidráulica da Escola de Engenharia de São Carlos com as sacolas construídas e o recipiente de plástico de adquirido, para verificação da 
resistência ao escoamento na saída do infiltrômetro, nas mangueiras, nos registros e nos recipientes.

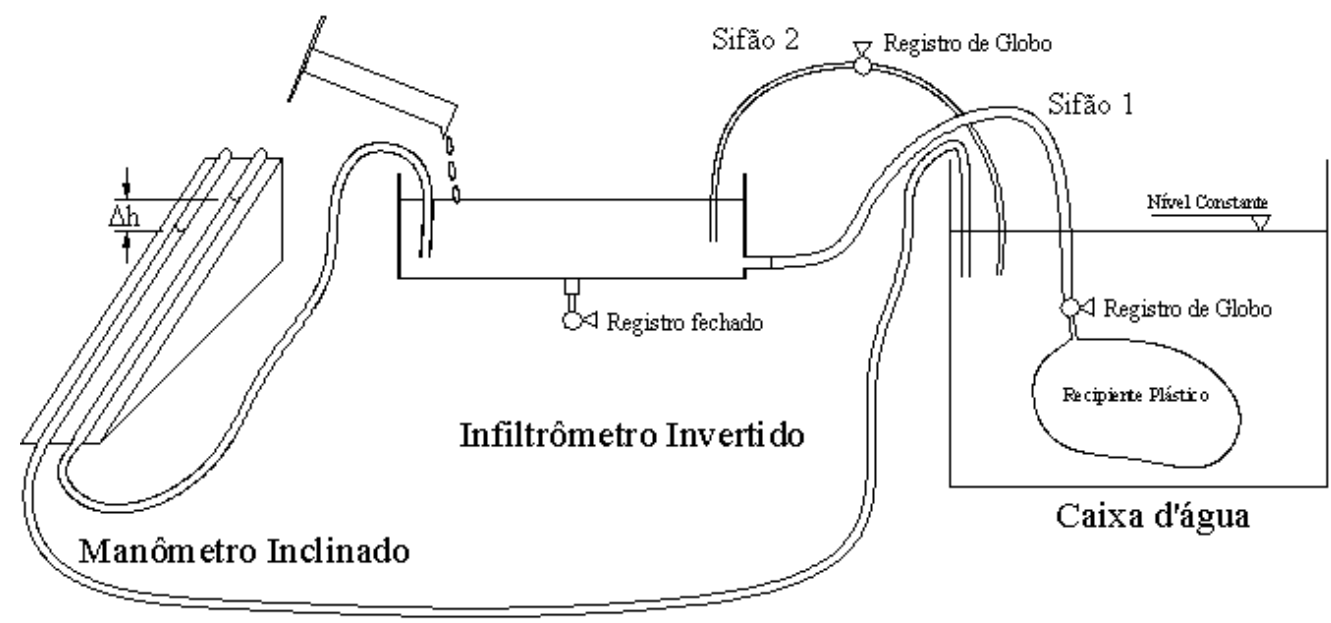

FIGURA 30 - Teste do Infiltrômetro e do recipiente plástico.

Antes da colocação do recipiente plástico e após ter sido enchido com água, retirouse todo ar contido em seu interior e fechou-se o registro. Colocou-se o recipiente plástico com água, previamente pesado, na caixa d'água acoplado-o à mangueira ligada ao infiltrômetro com o registro fechado. Igualaram-se os níveis d'água no infiltrômetro e na caixa d'água através de um sifão (Sifão 2 - FIGURA 30) com registro interligando esses dois reservatórios. Os níveis do infiltrômetro e da caixa d'água foram verificados em um manômetro inclinado, para melhorar a precisão das medidas.

Estando iguais os níveis do infiltrômetro e da caixa, fechou-se o registro do Sifão 2. Acrescentou-se um pequeno volume (1 ou 5 litros) de água no infiltrômetro com o registro acoplado ao recipiente plástico ainda fechado. Verificou-se que o nível no infiltrômetro era mais alto do que na caixa d'água equivalente ao volume acrescido. Abriu-se, então, o registro junto ao recipiente plástico e verificou-se a variação do nível no infiltrômetro ao longo do tempo, comparando com os ensaios do equipamento na configuração anterior. 
Para conhecermos a influência do recipiente plástico na resistência ao escoamento, realizou-se a comparação entre os ensaios com e sem a inserção deste recipiente de plástico.

\subsubsection{Resultados dos Testes.}

Os testes foram realizados com o acréscimo de 1 litro ou 5 litros, sendo, no último caso, realizado também o teste sem o recipiente plástico.

Para uma melhor representação e para a comparação entre os ensaios, adimensionalizou-se as alturas observadas em relação às alturas iniciais e finais.

$H=\frac{h_{i}-h_{o}}{h_{i}-h_{f}}$

onde $H$ é a altura adimensionalizada, $h_{i}$ altura inicial, $h_{o}$ altura observada e $h_{f}$ altura final.

Teste 1: (1 litro - com recipiente de plástico).

- Alturas da água (antes):

Infiltrômetro: 19,0 mm

Caixa d'água: 19,0 mm.

- Altura da água inicial no infiltrômetro após o acréscimo de 1 litro d'água: $23,0 \mathrm{~mm}$.

- Tempo aproximado de estabilização após abertura do registro: 1 hora e meia.

- Altura observada no infiltrômetro adimensionalizada com altura inicial apresentada na FIGURA 31. 


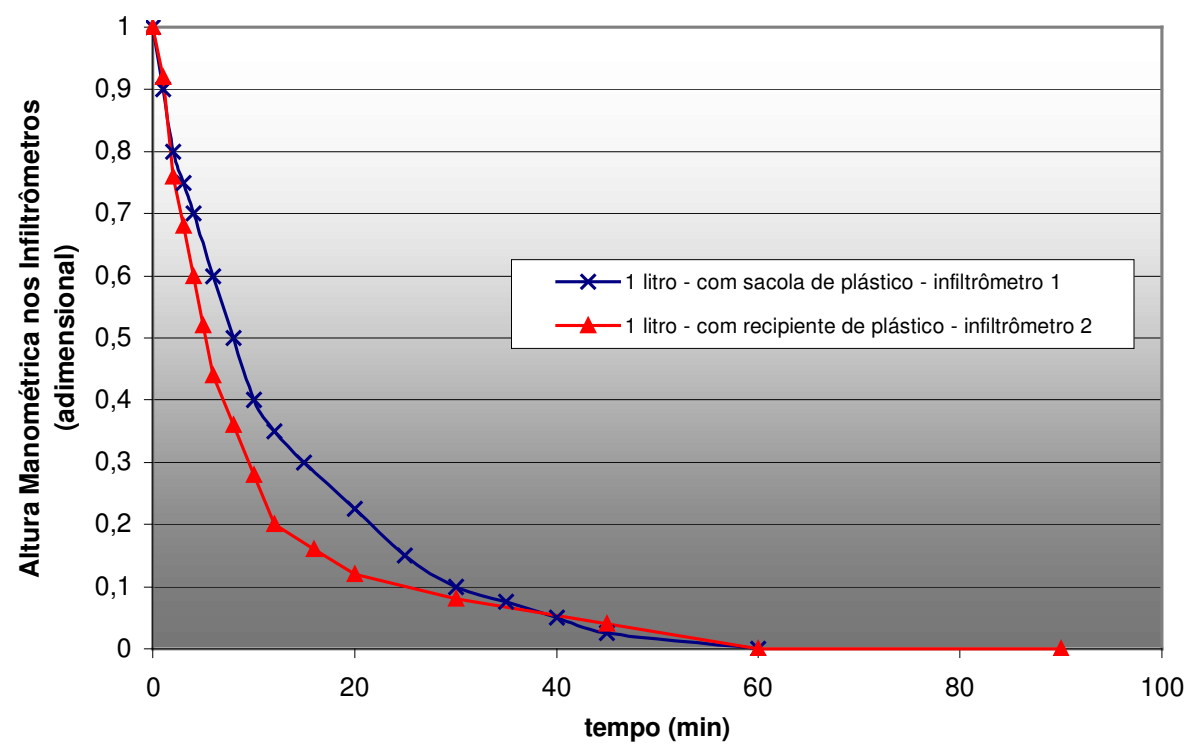

FIGURA 31 - Comparação da variação das alturas manométricas dos infiltrômetros 1 e 2 com acréscimo de 1 litro.

Teste 2: (5 litros - com recipiente de plástico).

- Alturas da água (antes):

Infiltrômetro: 19,0 mm

Caixa d'água: 19,0 mm.

- Altura d'água inicial no infiltrômetro após o acréscimo de 5 litros d'água: 36,8 $\mathrm{mm}$.

- Tempo aproximado de estabilização após a abertura do registro: 1 hora e meia.

- Altura observada no infiltrômetro adimensionalizada com altura inicial apresentada na FIGURA 32. 


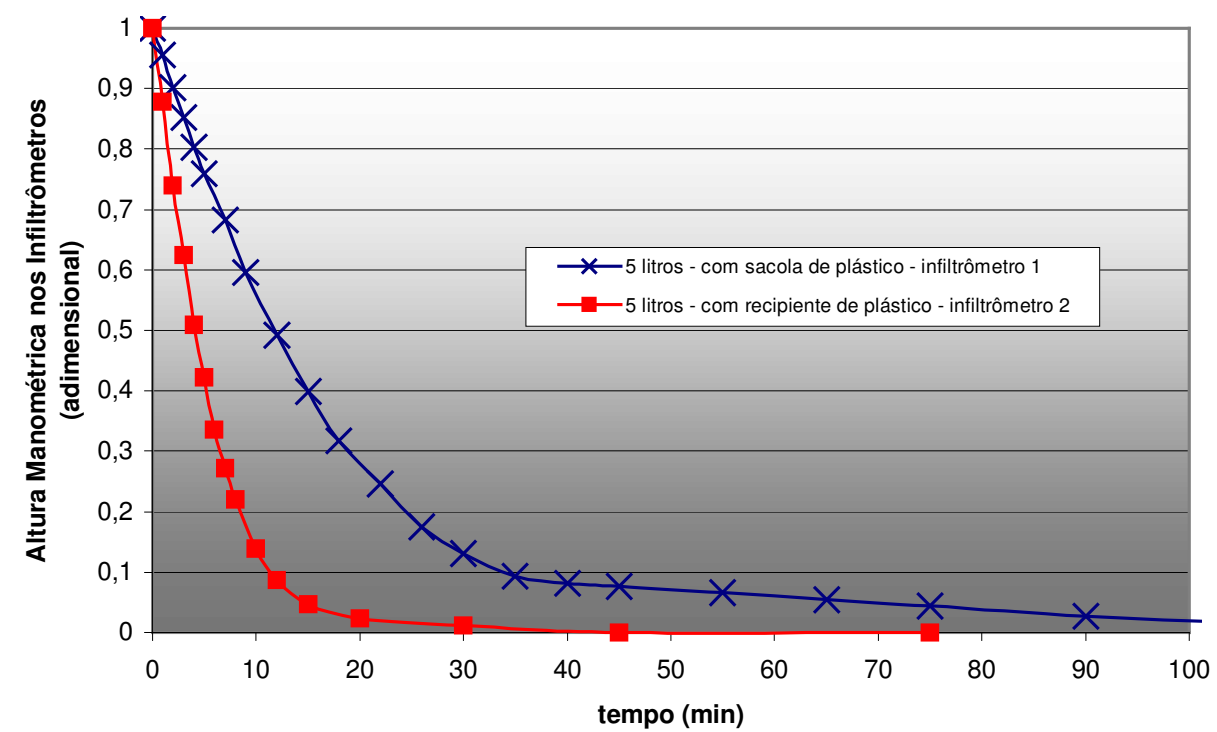

FIGURA 32 - Comparação da variação das alturas manométricas dos infiltrômetros 1 e 2 com acréscimo de 5 litros.

Teste 3: (5 litros - sem recipiente de plástico):

- Alturas da água (antes).

Infiltrômetro: 19,0 mm

Caixa d'água: 19,0 mm

- Altura d'água inicial no infiltrômetro com o acréscimo de 5 litros d'água: $36,8 \mathrm{~mm}$.

- Tempo aproximado de estabilização após a abertura do registro: 1 hora e meia.

- Altura observada no infiltrômetro adimensionalizada com altura inicial apresentada na FIGURA 33. 


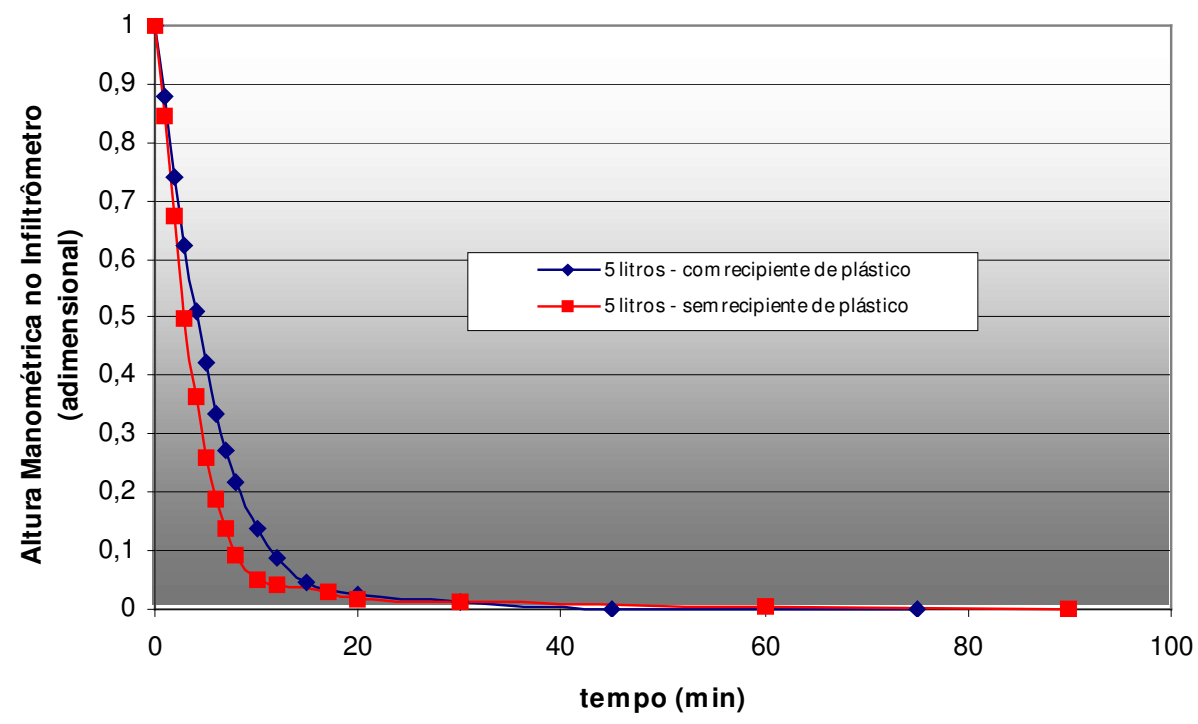

FIGURA 33 - Comparação da variação das alturas manométricas dos infiltrômetros com acréscimo de 5 litros com e sem recipiente de plástico.

\subsubsection{Conclusões dos testes.}

Comparando-se os ensaios com o equipamento nas configurações atuais com as anteriores, verifica-se que devido ao aumento do diâmetro das mangueiras, aumentou-se a vazão do escoamento, proporcionando-se, assim, uma maior confiabilidade do equipamento.

Comparando-se os rebaixamentos dos níveis de água nos infiltrômetros na forma adimensional entre os ensaios com e sem o recipiente plástico verificou-se que a resistência ao escoamento acrescida pela presença do recipiente de plástico para o infiltrômetro da segunda etapa é menor que aquele que ocorreu no caso do equipamento utilizado na primeira etapa. 


\subsection{Poços de Observação.}

Nas seções e estudo 1 e 2 do Ribeirão da Onça procurou-se caracterizar o padrão transversal de escoamento com auxilio de poço de observação. O espaçamento destes poços nas margens depende do relevo existente para caracterizar o perfil do lençol freático na seção transversal. Foram perfurados dois poços com auxilio de trado em cada uma das margens do rio e construíram-se estes de tubos de PVC.

Os níveis nos poços foram observados nos dias de realização de medidas da taxa de troca nas seções nos pontos de medidas e periodicamente durante a época de estudo.

Os poços de observação do nível freático nas proximidades dos pontos de medição da interação foram construídos com tubos de PVC em barras de 2 metros de comprimento e $50 \mathrm{~mm}$ de diâmetro. Esses tubos foram perfurados em todo o diâmetro até uma altura de aproximadamente 1,5 metro e também foi enrolado a uma manta de geotêxtil para impedir a entrada de solo no tubo (FIGURA 34).


FIGURA 34 - Tubos de PVC perfurados com geotêxtil e os trados tipo concha.

Através de um trado manual tipo concha de 3", perfurou-se o solo até encontrar o nível d'água, colocou-se um tubo de PVC de $75 \mathrm{~mm}$ de diâmetro. Com outro trado tipo concha de 2", perfurou-se internamente ao tubo colocado, empurrando para baixo até a 
profundidade total do poço. Colocou-se então o tubo de 2" já preparado com o geotêxtil dentro do tubo de $75 \mathrm{~mm}$. Retirou-se o tubo maior e completou-se o espaço anular ao redor do tubo de menor com parte do solo retirado.

Os poços onde os níveis d'água eram de uma profundidade maior que 2 metros, foram perfurados através do mesmo método, mas emendou-se mais uma barra de 2 metros tanto no tubo de $75 \mathrm{~mm}$ como no de $50 \mathrm{~mm}$, sendo a parte superior do tubo do poço sem geotêxtil.

No total foram construídos seis poços de observação do nível freático, sendo dois na seção 1 mais a jusante e quatro na seção 2 .

Foi executado o levantamento topográfico para localização dos poços e determinação de suas cotas em relação ao rio.

\subsection{Mini-Piezômetros.}

LEE e CHERRY (1978) apresentaram um mini-piezômetro construído no leito do rio. Esse dispositivo foi utilizado tanto para a medida de interação como para determinação da condutividade hidráulica da parte do aqüífero logo abaixo do leito do rio. As diversas etapas para instalação de mini-piezômetros estão ilustradas na FIGURA 35.

O mini-piezômetro é construído introduzindo-se um tubo de ferro com uma rolha inserida na ponta inferior para impedir a entrada de material do fundo do rio para dentro do tubo. Após o cravamento de aproximadamente 1,0 m bate-se com uma barra de ferro, por dentro do tubo para que a rolha se desprenda. Levantando-se o tubo um pouco, coloca-se então, dentro do tubo, uma mangueira transparente de menor diâmetro com um filtro na ponta, retirando em seguida o tubo de ferro com cuidado.

Após a estabilização dos níveis verifica-se que o nível na mangueira é maior que o do rio. Esse desnível, juntamente com o valor quantificado da interação rio aqüífero através 
de um infiltrômetro ou através do acoplamento de uma sacola plástica no mini-piezômetro, é utilizado para o cálculo da condutividade hidráulica

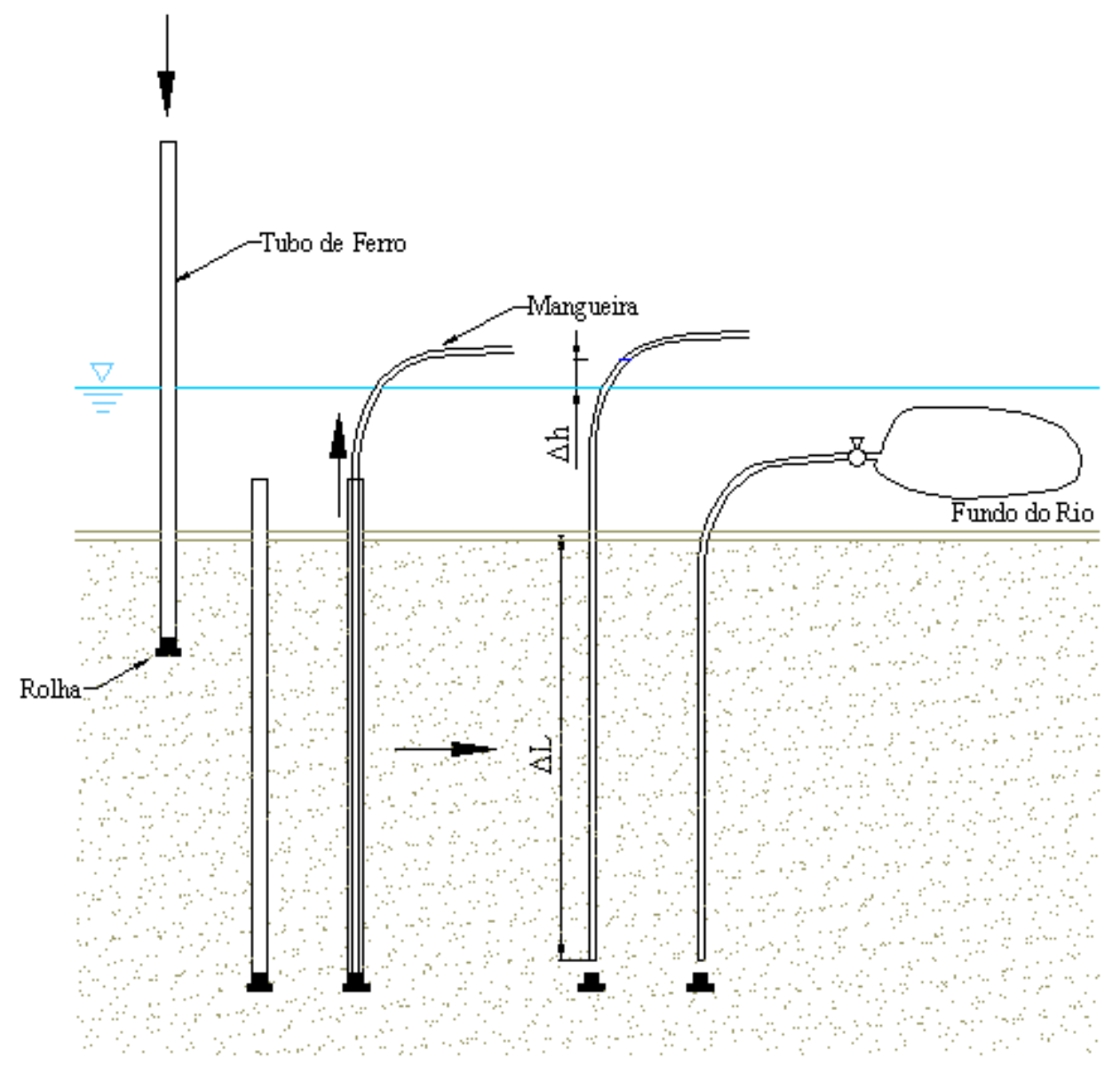

FIGURA 35 - Mini-piezômetro similar ao descrito por LEE e CHERRY (1978).

Para conhecermos a condutividade hidráulica do leito do Ribeirão da Onça nas seções de estudo foram construídos dois mini-piezômetros. Na seção 2, um mini-piezômetro igual ao apresentado por LEE e CHERRY (1978) foi instalado. Para quantificação da condutividade hidráulica na seção 3 construiu-se um mini-piezômetro um pouco diferente, como pode ser visualizado na FIGURA 36. 


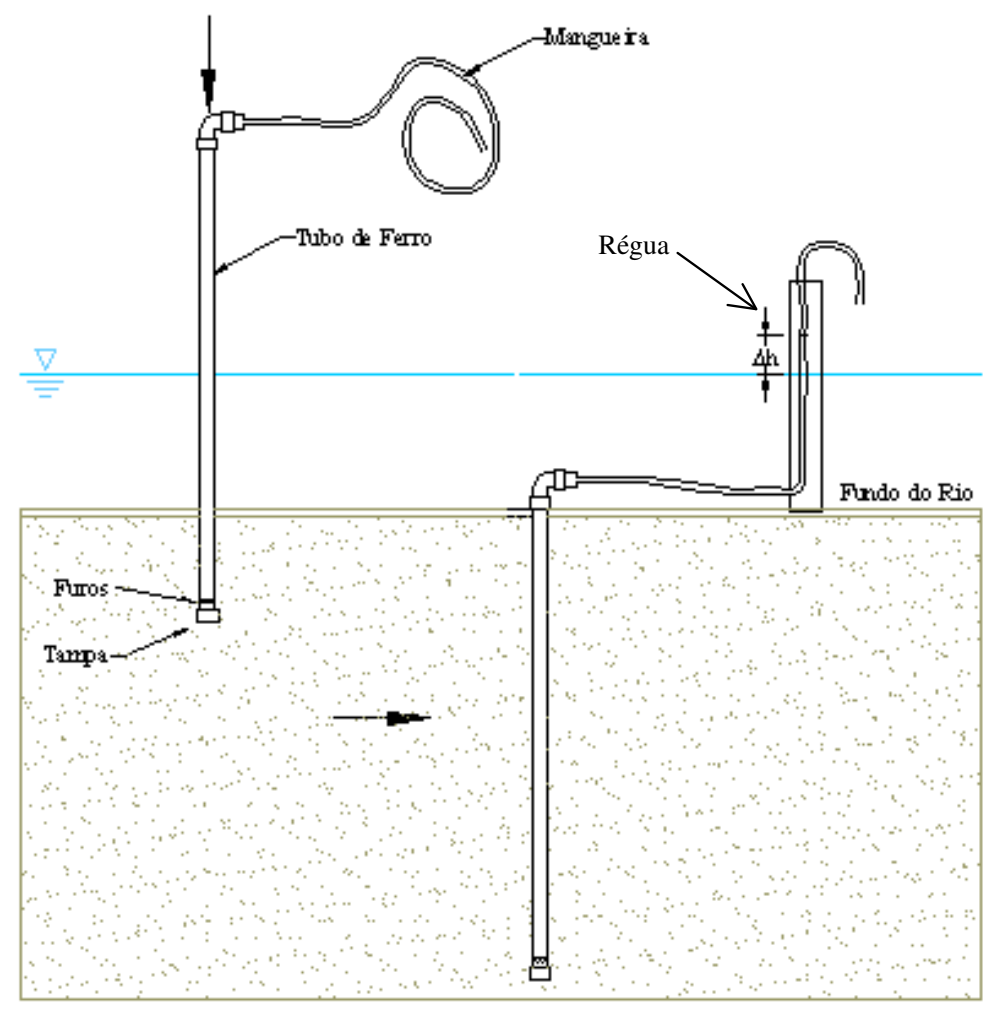

FIGURA 36 - Mini-piezômetro aprimorado.

Na seção 2, o tubo de ferro com a rolha na ponta foi cravado a uma profundidade de 0,8 metro. Não foi possível cravar a uma profundidade maior, porque o solo ofereceu resistência devido à presença de pedregulhos. Com uma barra de ferro desacoplou-se a rolha da ponta. Colocou-se então uma mangueira com diâmetro de $1,0 \mathrm{~cm}$ no interior do tubo, após isto, foi retirado com cuidado para não levantar a mangueira. Uma régua foi colocada junto à mangueira para determinação do desnível. Após alguns dias para estabilização dos níveis quantificou-se esse desnível.

Já na seção 3, o tubo foi cravado a uma profundidade de 0,9 metro do fundo. Este mini-piezômetro não necessita a retirada da rolha, pois o fundo do tubo é fechado e o tubo de ferro não é retirado. A carga hidráulica é medida em relação a furos nas laterais do tubo cravado. A profundidade utilizada para o cálculo da condutividade hidráulica é a distância entre a linha dos furos e o fundo do rio $(\Delta \mathrm{L})$. Um pedaço de manta geotêxtil foi colocada na 
altura dos furos, internamente ao tubo, para impedir a entrada de material granular. Assim como o mini-piezômetro da seção 2, utilizou-se uma régua para determinar os desníveis, e a mangueira é acoplada ao tubo através de um espigão acoplado ao tubo de ferro.

\subsection{Granulometria.}

Foram realizados ensaios de granulometria de amostras do leito do rio retiradas nas seções dos três pontos em estudo. As amostras foram coletadas através de um tubo de PVC de $50 \mathrm{~mm}$ com uma tampa na parte superior (conhecido como amostrador de KOR). Esse tubo foi cravado no fundo do rio, tampado no topo e retirado para coleta da amostra. A profundidade da amostra coletada foi em torno de $80 \mathrm{~cm}$.

\subsubsection{Descrição do Ensaio Granulométrico.}

Para as seções 1 e 2, o ensaio de peneiramento simples foi suficiente para determinação da granulometria, pois as amostras não continham finos. Já para a seção 3, as amostras de fundo continham quatro camadas de aproximadamente $15 \mathrm{~cm}$ cada, com textura e coloração diferentes, devido à presença de finos e matéria orgânica, e a granulometria conjunta foi determinada para essas quatro camadas.

Para o ensaio disponibilizaram-se 200 gramas de cada amostra arenosa e 70 de uma amostra com finos. Com as quatro amostras da seção 3, realizaram-se os ensaios de sedimentação e, após secagem, o peneiramento. As peneiras utilizadas foram as de número 4, 10, 16, 30, 50, 140 e 200 da ABNT. As figuras 36 a 41 apresentam as curvas granulométricas com composição da amostras e outros parâmetros.

Os dados da curva granulométrica foram analisados com vista à determinação dos parâmetros $d_{10}$ e $d_{60}$ e $C_{u}$ definidos como:

$d_{10}$ : Diâmetro dos grãos para $10 \%$ de passagem na curva granulométrica. 
$d_{60}$ : Diâmetro dos grãos para $60 \%$ de passagem na curva granulométrica.

$C_{u}=\frac{d_{60}}{d_{10}}$, Coeficiente de Uniformidade

Os solos podem ser caracterizados como:

$C_{u}<5=>$ Solo muito uniforme;

$5<C_{u}<15 \Rightarrow$ Solo de media uniformidade;

$C_{u}>15=>$ Solo desuniforme;

Verifica-se que quatro das cinco amostras arenosas foram classificadas como areia média a fina. Apenas duas das seis amostras apresentaram-se como de areia média. Cinco amostras indicaram serem de solo muito uniforme. Já a amostra de fundo da seção 3 é caracterizada como uma areia silte-argilosa. Essa grande diferença das características da última camada se deve à presença de matéria orgânica $(17,3 \%$ da massa - quantificada através da queima em mufla). 


\section{Seção 1.}



FIGURA 37 - Curva granulométrica da seção 1

$40 \%$ de areia fina.

$57 \%$ de areia média.

$3 \%$ de areia grossa.

$d_{10}=0,12 \mathrm{~mm}$.

$d_{60}=0,27 \mathrm{~mm}$.

$C_{u}=2,25$

Classificação: Areia média a fina, uniforme. 
Seção 2.

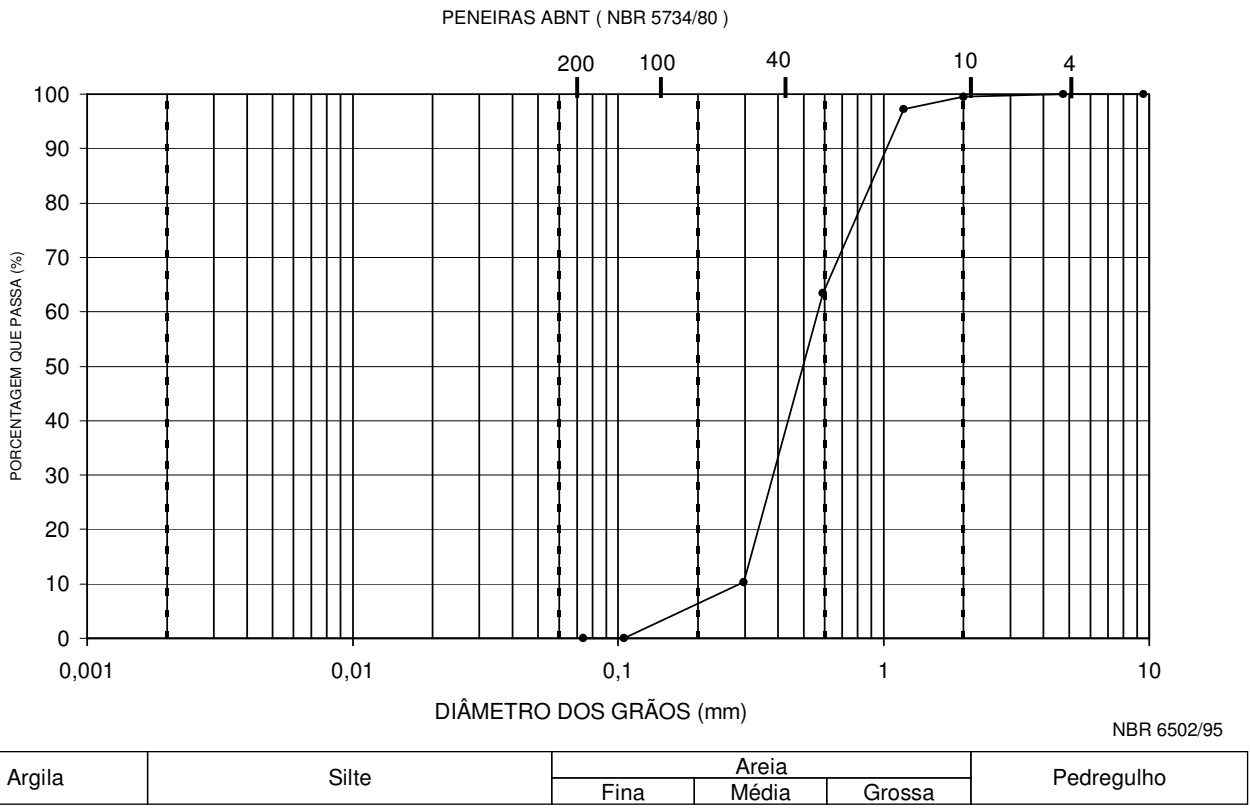

FIGURA 38 - Curva granulométrica da seção 2.

$7 \%$ de areia fina.

$56 \%$ de areia média.

$37 \%$ de areia grossa.

$d_{10}=0,29 \mathrm{~mm}$.

$d_{60}=0,57 \mathrm{~mm}$.

$C_{u}=1,9$

Classificação: Areia média, uniforme. 
Seção 3.

- Camada 1 (Superior):

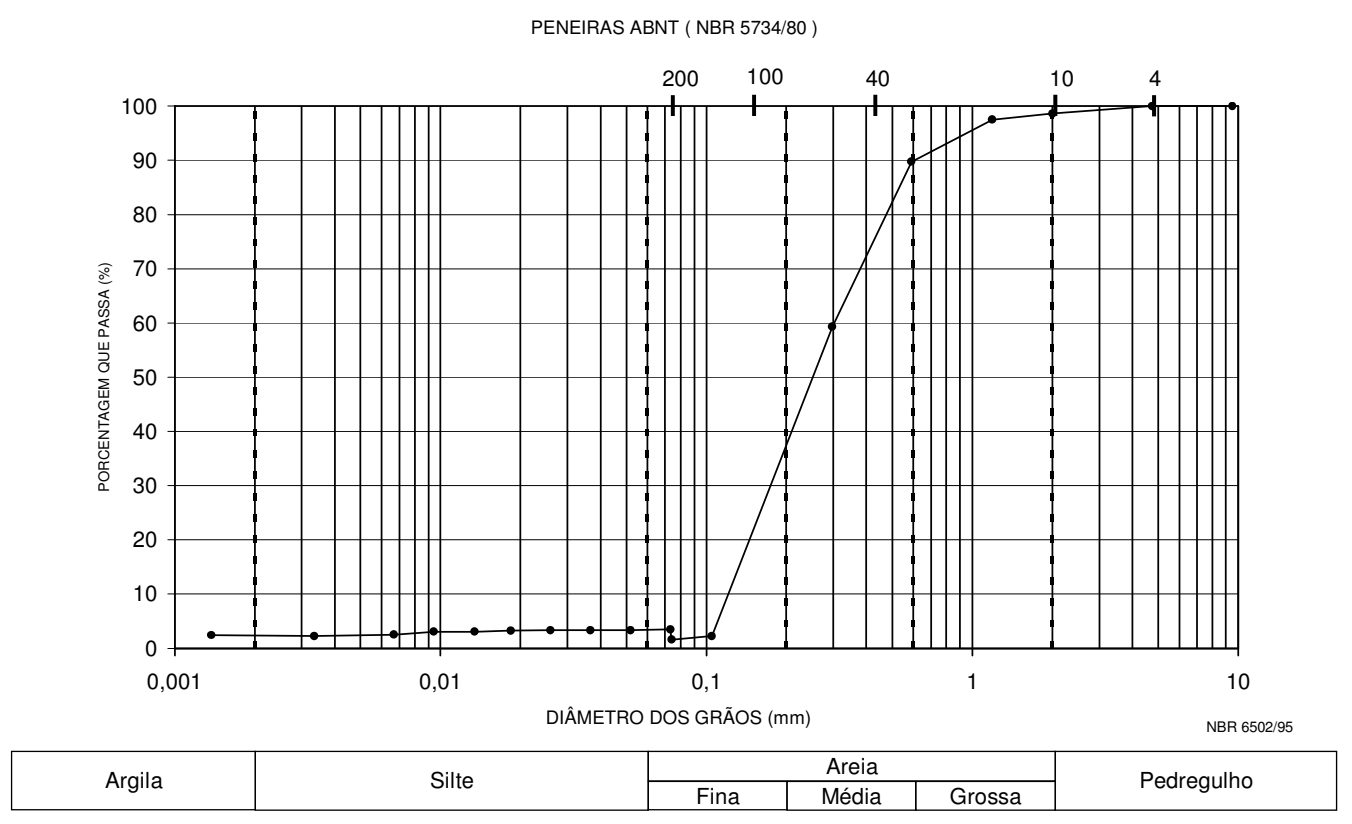

FIGURA 39 - Curva granulométrica da seção 3 (Camada 1).

$2 \%$ de argila.

$36 \%$ de areia fina.

$52 \%$ de areia média.

$9 \%$ de areia grossa.

$1 \%$ de pedregulho.

$d_{10}=0,13 \mathrm{~mm}$.

$d_{60}=0,30 \mathrm{~mm}$.

$C_{u}=2,30$

Classificação: Areia média a fina, uniforme. 
- Camada 2 (Intermediária 1):

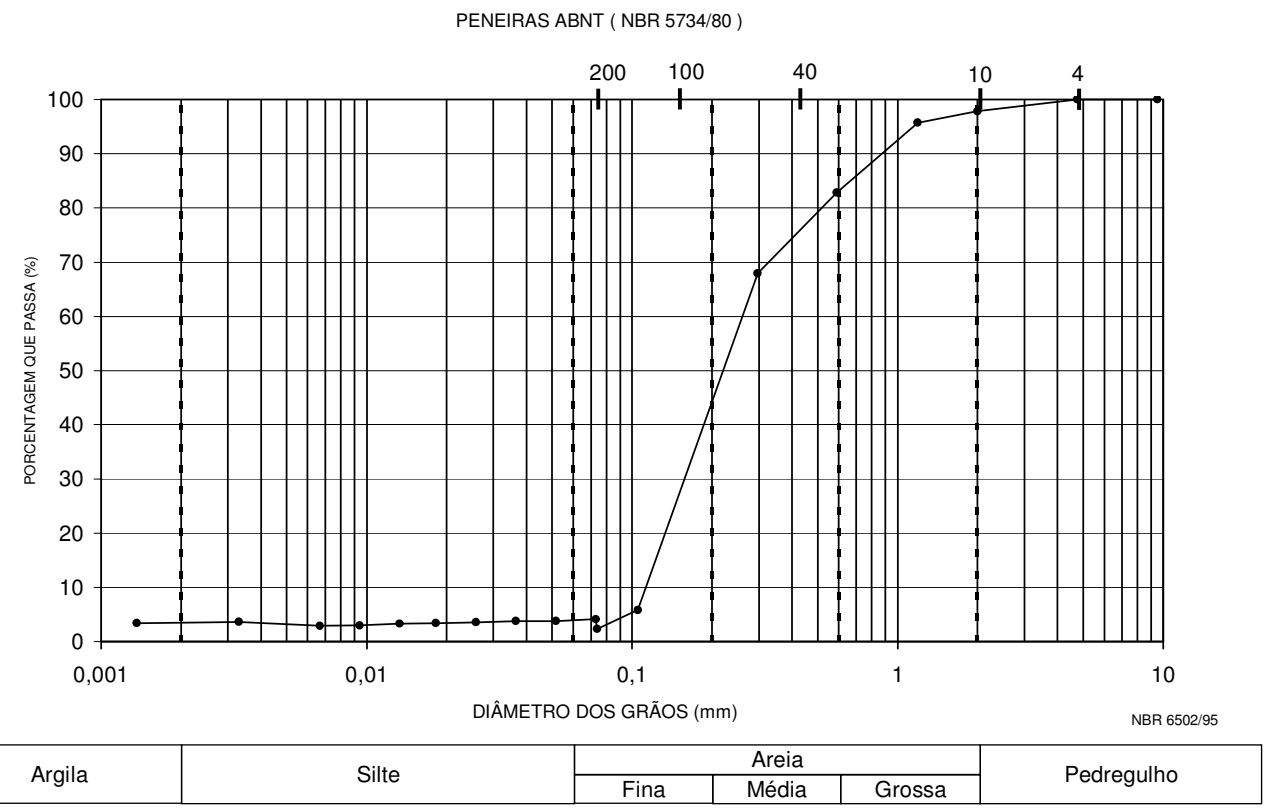

FIGURA 40 - Curva granulométrica da seção 3 (Camada 2).

$4 \%$ de argila.

$41 \%$ de areia fina.

$37 \%$ de areia média.

$16 \%$ de areia grossa.

$2 \%$ de pedregulho.

$d_{10}=0,12 \mathrm{~mm}$.

$d_{60}=0,27 \mathrm{~mm}$.

$C_{u}=2,25$

Classificação: Areia média a fina, uniforme. 
- Camada 3 (Intermediária 2):

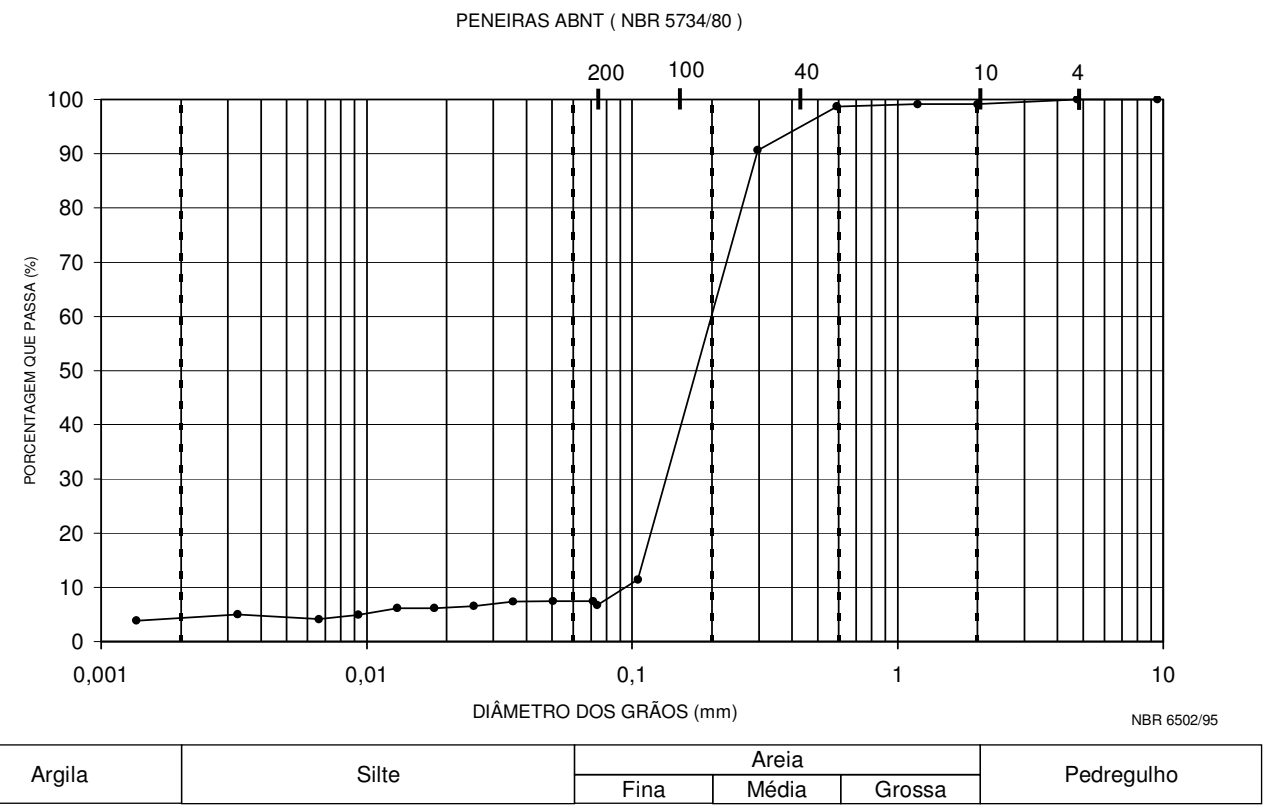

FIGURA 41 - Curva granulométrica da seção 3 (Camada 3).

$4 \%$ de argila.

4\% de silte.

$52 \%$ de areia fina.

$39 \%$ de areia média.

$1 \%$ de areia grossa.

$d_{10}=0,10 \mathrm{~mm}$.

$d_{60}=0,20 \mathrm{~mm}$.

$C_{u}=2,00$

Classificação: Areia fina a média, uniforme. 
- Camada 4 (Argila de fundo $\approx 60 \mathrm{~cm}$ ):

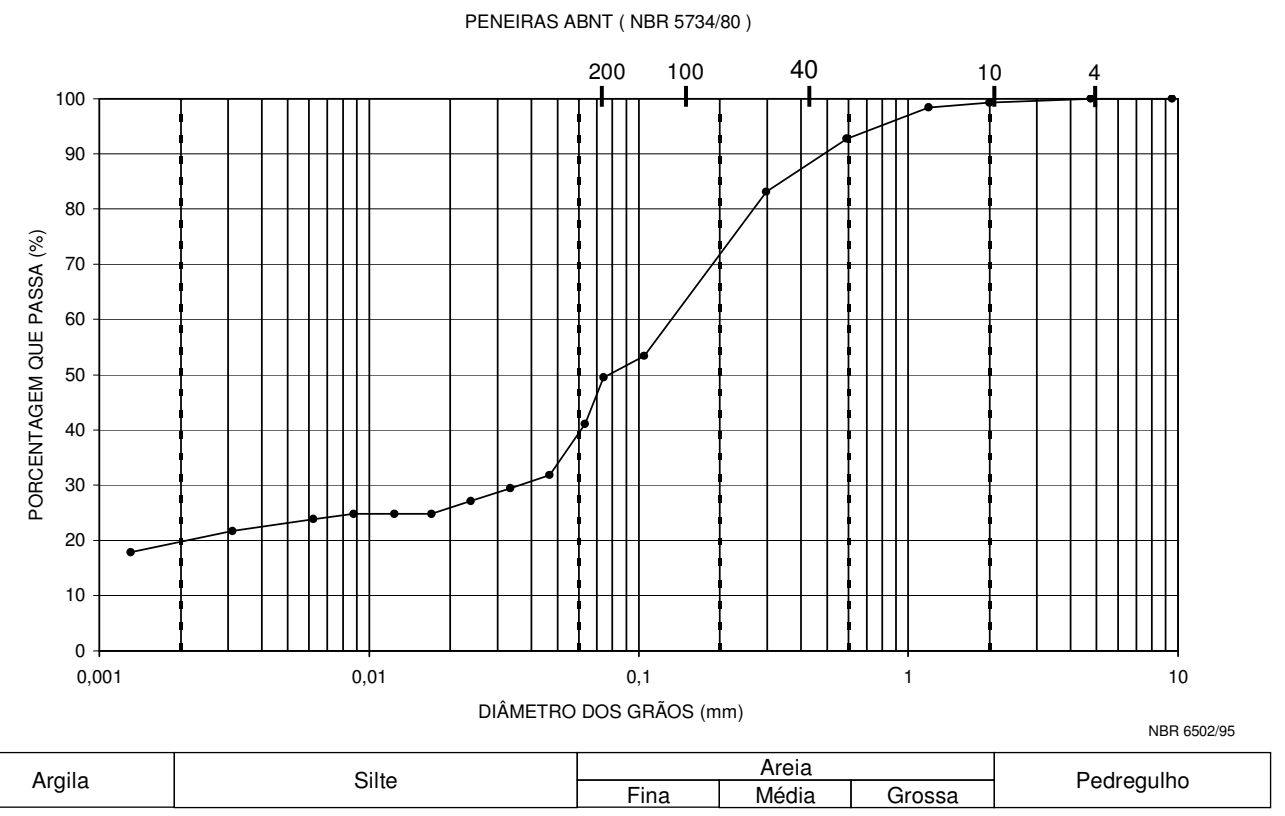

FIGURA 42 - Curva granulométrica da seção 3 (Camada 4).

$20 \%$ de argila.

$20 \%$ de silte.

$32 \%$ de areia fina.

$21 \%$ de areia média.

$7 \%$ de areia grossa.

$d_{10}=$ muito pequeno.

$d_{60}=0,14 \mathrm{~mm}$.

Classificação: Areia fina a média silte-argilosa, muito desuniforme. 


\section{ANÁLISE DOS RESULTADOS.}

\subsection{Medidas da Interação Rio - Aqüífero.}

Após reconstrução e testes dos novos infiltrômetros, obtiveram-se dados a partir de novos ensaios de campo nas seções de estudo da bacia. No total, foram realizadas 82 visitas ao campo para medida da interação rio-aqüífero de 15 julho de 2002 à 14 de fevereiro de 2003, sendo realizadas 45 medidas na seção 1,76 na seção 2 e 40 medidas na seção 3 . Os valores observados das características da interação rio-aqüífero, em termos da taxa de troca, foram representados graficamente para o período em estudo (FIGURA 43). Nas três seções de estudo, verificou-se que o fluxo ocorre do aqüífero para o rio. Acredita-se que o Ribeirão da Onça seja caracterizado por um rio surgente em todo o seu leito.

Nos primeiros dias das medições da interação, verificou-se que existia uma oscilação nos valores da vazão de surgimento nos dias consecutivos. Buscou-se, então, uma justificativa para essa descontinuidade. Com base na bibliografia sobre posição das superfícies piezométricas dos aqüíferos, pensou-se que a variação da pressão atmosférica poderia influenciar na quantificação da interação, procedendo-se a comparação dos valores encontrados de taxa de surgimento $(\mathrm{mm} /$ dia) com a pressão atmosférica nos horários dos ensaios. Tendo em vista uma relação inversa existente entre a pressão e vazão de surgimento, a FIGURA 44 apresenta a variação da pressão numa escala decrescente para cima com a finalidade de facilitar a comparação entre as FIGURAS 43 e 44 . Confirma-se que a taxa de surgimento comporta-se inversamente com o aumento da pressão, pois os aumentos nas referidas taxas coincidem com a redução da pressão, diminuindo a diferença da carga 
hidráulica entre o rio e aqüífero. Esta relação é mais nítida nos períodos de 15 de julho a 15 de agosto e 23 de agosto a 13 de setembro, nos quais não houve precipitação. O restante do período de observação é marcado por chuvas ocasionais, fato este que dificulta estudos da variabilidade da taxa de surgimento apenas em termos de variação de pressão. Realizaram-se mais adiante tentativas de estudo da relação entre taxa de surgimento e pressão.

Para visualização, também da influência da precipitação na taxa de surgimento, apresentam-se na FIGURA 45 os valores de precipitação diária no período de estudo. Para visualizar a variação sazonal da interação, a FIGURA 46 mostra os valores médios mensais do surgimento nas três seções de estudo e também as precipitações durante esses meses.

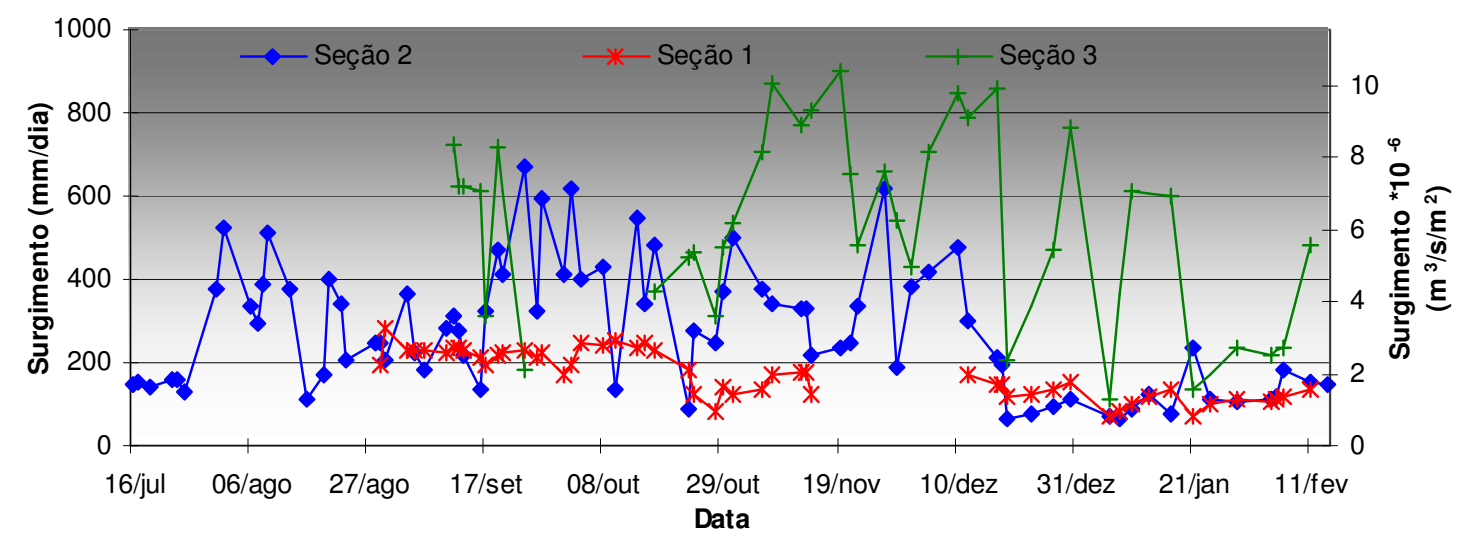

FIGURA 43 - Interação rio-aqüífero nas seções 1, 2 e 3.

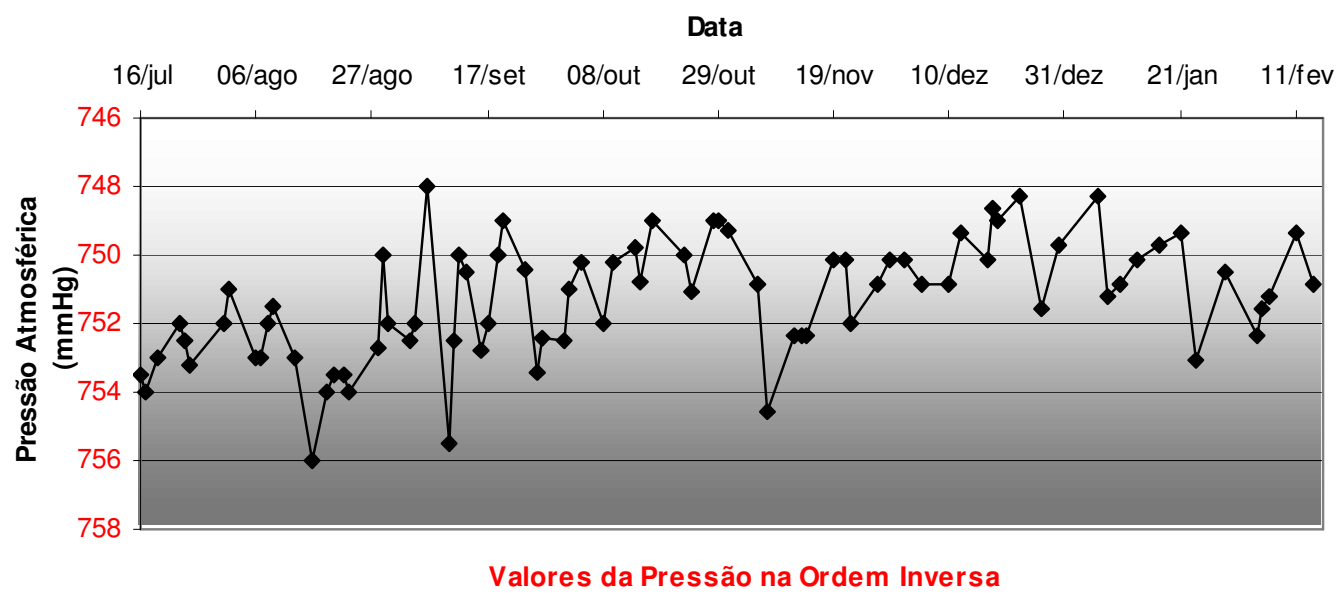

FIGURA 44 - Variação da pressão atmosférica no horário da visita ao campo. 


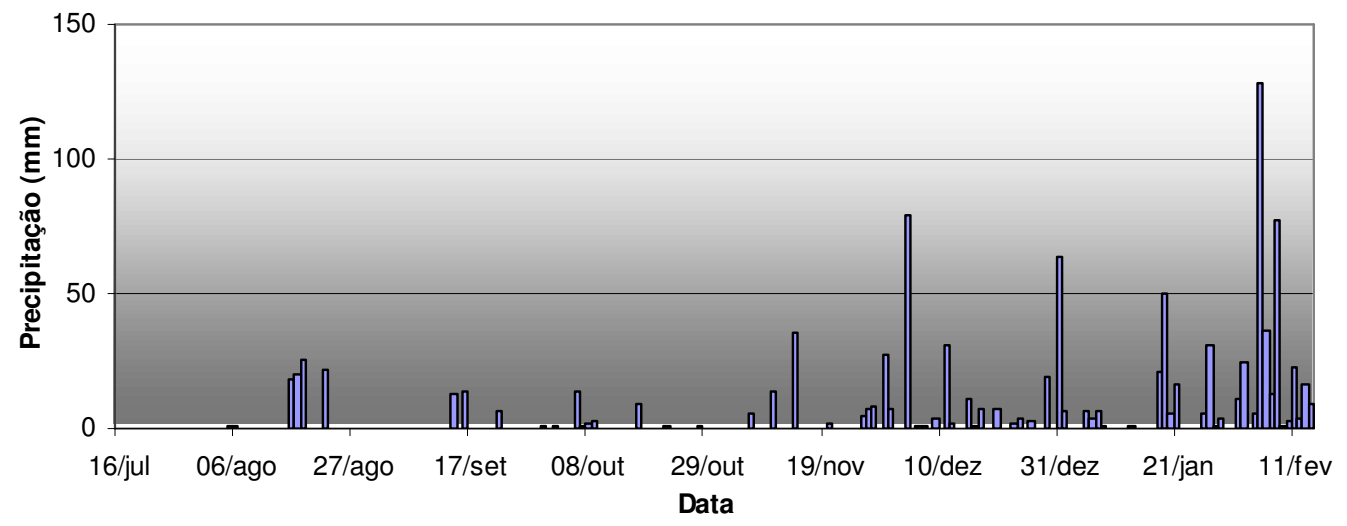

FIGURA 45 - Precipitação diária durante o período dos ensaios.



FIGURA 46 - Comparação das médias mensais do surgimento nas seções 1, 2 e 3.

Os valores da taxa de surgimento no período estudado variaram de 62,0 a 901,0 mm/dia nas três seções. Na TABELA 02, apresentam-se os valores máximo, mínimo e médio para as três seções de estudo. Verifica-se que a taxa de surgimento aumenta de jusante para montante. A explicação para essa diferença pode ser a maior altura da lamina d'água da seção a jusante em relação à montante. 
TABELA 02 - Valores da taxa de surgimento (mm/dia) para as três Seções de Estudo.

\begin{tabular}{|c|c|c|c|}
\cline { 2 - 4 } \multicolumn{1}{c|}{} & Seção 1 & Seção 2 & Seção 3 \\
\hline Máximo & 285,21 & 670,60 & 901,03 \\
\hline Médio & 175,01 & 290,15 & 556,45 \\
\hline Mínimo & 67,91 & 62,07 & 112,86 \\
\hline
\end{tabular}

Com relação à variabilidade temporal da taxa de surgimento, pode-se dividir o período de estudo em duas partes: inicial, com pouca chuva, até aproximadamente o final de novembro e a parte final com maior intensidade de chuva, principalmente nos meses de dezembro, janeiro e fevereiro. Comparando-se a taxa de surgimento do período menos chuvoso com o chuvoso (FIGURAS 43, 45 e 46), verifica-se que houve uma diminuição do surgimento com a chuva. $\mathrm{O}$ aumento do nível d'água no rio mais rápido em relação ao aumento do nível do lençol freático com as chuvas, pode ser a causa dessa diminuição da taxa. Um fenômeno semelhante ao armazenamento de margem, descrito na revisão bibliográfica, pode ter ocorrido mas em nosso estudo não houve a inversão do fluxo.

\subsection{Variação Temporal da Vazão do Ribeirão da Onça.}

A vazão na Seção de estudo 2 foi estimada através dos níveis d'água do rio medidos nos dias de visita ao campo aplicando-se a curva-chave apresentada na FIGURA 24. O conhecimento do hidrograma do escoamento superficial, bem como a estimativa do escoamento básico, são importantes na análise comparativa entre o surgimento medido pontualmente e o escoamento básico que de fato ocorre nessa seção de estudo. Na FIGURA 47 apresenta-se o hidrograma para a seção 2. 


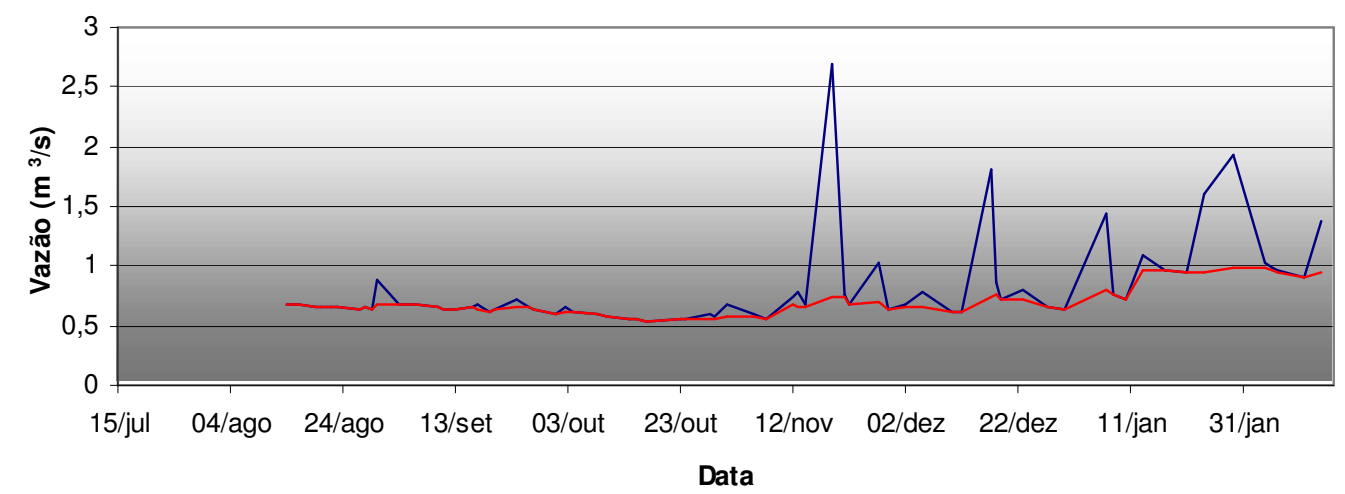

FIGURA 47 - Hidrograma no período de estudo (Com separação do escoamento superficial e básico).

No início do estudo de campo, o escoamento básico diminuiu até aproximadamente o final de outubro. De novembro até o final dos estudos houve um aumento no escoamento básico devido à chegada do período chuvoso, que se deu de forma mais acentuada no inicio de janeiro.

O surgimento de fundo e também o afloramento nas laterais do rio são responsáveis pela formação do escoamento básico. Considerando-se que as medidas do surgimento através dos infiltrômetros tiveram uma pequena diminuição no período mais chuvoso, acredita-se que o aumento do escoamento básico se dá devido aos aumentos da área de afloramento laterais ao rio e do gradiente hidráulico.

\subsection{Uma Estimativa da Grandeza da Taxa de Surgimento.}

Para certificação da validade dos ensaios com os infiltrômetros, procurou-se uma estimativa da taxa de troca entre o rio e o aqüífero. Considerando-se que a vazão em períodos de estiagem (escoamento básico) é formada pelo surgimento em todo o leito do rio e em suas a margens, construiu-se um raciocínio para estimativa da taxa de surgimento medida por meio de infiltrômetros. 
Utilizando mapas apresentados por CONTIN (1987) com as características da bacia em estudo, é possível estimar o valor da interação rio-aqüífero, fazendo o seguinte cálculo:

$q_{s}=\frac{Q_{b}}{L \cdot B}$

onde $\mathrm{q}_{\mathrm{s}}[\mathrm{m} / \mathrm{s}]$ é a taxa de surgimento, e sendo:

- comprimento total dos cursos d'água (L), até a seção $2=38,62 \mathrm{~km}$.

- vazão de base média do Ribeirão da Onça (em uma seção de estudo - Seção 2)durante a estiagem, $\overline{Q_{b}} \approx 0,610 \mathrm{~m}^{3} / \mathrm{s}$.

Observa-se que o afloramento depende da topografia variável das margens e da seção do rio na extensão sob análise. Observações de campo e do mapa topográfico mostram que as larguras das margens com afloramento variam de nulo (existência de barrancos) a dezenas de metros. As grandezas das larguras das margens aflorantes nas seções são da mesma ordem que os perímetros molhados das seções.

- Largura da seção do Ribeirão da Onça $\approx 5$ m.

- Largura média dos afloramentos de margem $\approx 5 \mathrm{~m}$.

- Largura média total da área de contribuição do aqüífero ao rio, $\mathrm{B} \approx 10$ metros.

O valor encontrado para $\mathrm{q}_{\mathrm{s}}$ é da ordem de $1,58 * 10^{-6} \mathrm{~m} / \mathrm{s}$ ou $136,5 \mathrm{~mm} / \mathrm{dia}$.

Nos resultados das medidas de campo, apresentado na FIGURA 43, para o período de estiagem, encontra-se um valor médio para o surgimento de $\approx 3,0 * 10^{-6} \mathrm{~m} / \mathrm{s}$ ou $\approx 260$ mm/dia, que é de mesma ordem que a estimativa para o surgimento apresentada acima.

\subsection{Determinação da Condutividade Hidráulica Através de Mini-piezômetros e Granulometria.}

Para a caracterização do fundo do rio nas seções de estudo, procedeu-se a determinação da condutividade hidráulica. Para tanto, empregaram-se mini-piezômetros nas 
seções 2 e 3, conforme a descrição no Item 5.6. A condutividade hidráulica também foi estimada através dos dados de granulometria utilizando o método de HAZEN (1911).

Na equação generalizada de Darcy:

$\mathrm{Q}=\mathrm{A} \frac{\mathrm{dh}}{\mathrm{dl}} \mathrm{K}$

$\mathrm{O}$ gradiente hidráulico $\mathrm{dh} / \mathrm{dl}$ pode ser aproximado por $\Delta \mathrm{h} / \Delta \mathrm{L}$. A profundidade do ponto de medida da carga hidráulica no fundo do rio $(\Delta \mathrm{L})$ é igual a $0,9 \mathrm{~m}$ para a seção 3 . A vazão de surgimento medida no dia de ensaio, Q; a área do tambor, A; e os valores dos desníveis, $\Delta \mathrm{h}$, nos quatro dias de ensaios realizados com os mini-piezômetros, juntamente com a condutividade hidráulica calculada, são apresentados na TABELA 03

TABELA 03 - Determinação da Condutividade Hidráulica na Seção 3.

\begin{tabular}{|c|c|c|c|c|c|}
\hline Data & $\begin{array}{c}\Delta \mathrm{h} \\
(\mathrm{m})\end{array}$ & $\begin{array}{c}\text { Gradiente } \\
\text { hidráulico } \\
\Delta \mathrm{h} / \Delta \mathrm{L}\end{array}$ & $\begin{array}{c}\text { Vazão } \\
\mathrm{Q}(\mathrm{m} / \mathrm{s})\end{array}$ & $\begin{array}{c}\text { Área do } \\
\text { tambor } \\
\mathrm{A}\left(\mathrm{m}^{2}\right)\end{array}$ & $\begin{array}{c}\text { Condutividade } \\
\text { Hidráulica } \\
\mathrm{K}(\mathrm{m} / \mathrm{s})\end{array}$ \\
\hline $04 / 02 / 2003$ & 0,017 & 0,019 & $6,42 * 10^{-7}$ & 0,255 & $1,33 * 10^{-4}$ \\
\hline $06 / 02 / 2003$ & 0,019 & 0,021 & $7,00 * 10^{-7}$ & 0,255 & $1,30 * 10^{-4}$ \\
\hline $11 / 02 / 2003$ & 0,018 & 0,020 & $1,42 * 10^{-6}$ & 0,255 & $2,78 * 10^{-4}$ \\
\hline $14 / 02 / 2003$ & 0,021 & 0,023 & $1,33 * 10^{-6}$ & 0,255 & $2,24 * 10^{-4}$ \\
\hline
\end{tabular}

Para a seção 2, quantificou-se a condutividade hidráulica para somente um dia, pois o entupimento da mangueira impediu medidas posteriores. Os valores dos diversos parâmetros foram:

$$
\begin{aligned}
& \Delta \mathrm{L}=0,8 \mathrm{~m} . \\
& \mathrm{Q}=6,94 * 10^{-7} \mathrm{~m} / \mathrm{s} . \\
& \Delta \mathrm{h}=0,037 \mathrm{~m}
\end{aligned}
$$

$\mathrm{O}$ valor da condutividade hidráulica determinada para a seção 2 , é $\mathrm{K}=5,88 \times 10^{-4}$ $\mathrm{m} / \mathrm{s}$.

Um método alternativo para estimativa da condutividade hidráulica é através da granulometria utilizando-se o método de HAZEN expresso como: 
$K=C * d_{10}^{2} * 10^{-4}$

onde C é um coeficiente que varia de 100 a 120. Para a areia média que constitui o fundo do Ribeirão da Onça adota-se o valor médio de C $=100$.

Na TABELA 04 apresenta-se essa estimativa para as três seções de estudo, sendo que na seção 3 determinou-se a condutividade hidráulica para três camadas retiradas com o amostrador.

TABELA 04 - Estimativa da Condutividade Hidráulica.

\begin{tabular}{|c|c|c|c|}
\hline Amostras & $d_{10}$ & $\mathrm{~K}(\mathrm{~m} / \mathrm{s})$ \\
\hline \multicolumn{2}{|c|}{ Seção 1 } & 0,12 & $1,44 * 10^{-4}$ \\
\hline \multicolumn{2}{|c|}{ Seção 2 } & 0,30 & $9,00 * 10^{-4}$ \\
\hline \multirow{3}{*}{ Seção 3 } & Camada 1 & 0,13 & $1,69 * 10^{-4}$ \\
\cline { 2 - 4 } & Camada 2 & 0,12 & $1,44 * 10^{-4}$ \\
\cline { 2 - 4 } & Camada 3 & 0,10 & $1,00 * 10^{-4}$ \\
\hline
\end{tabular}

A condutividade hidráulica encontrada utilizando-se o ensaio granulométrico (TABELA 04) possui ordem de grandeza similar aos ensaios com os mini-piezômetros (TABELA 03), tanto para a seção 2 como para seção 3.

\subsection{Variação dos Níveis Freáticos.}

Para a seção 1, as medidas de níveis de água em poços de observação iniciaram-se no começo de setembro. Na FIGURA 48 é visualizada a variação dos níveis para os poços 5 e 6, localizados à margem esquerda da seção 1 , juntamente com a variação do nível d'água do rio para essa seção. 




FIGURA 48 - Variações das cotas do nível d'água e dos poços de observação nas proximidades da seção 1 e precipitação.

Para a seção 2 as medidas dos poços de observação iniciaram-se em meados de agosto, totalizando seis meses de medidas. As variações dos níveis de água nos poços 1, 2, 3 e 4 e do nível do rio nesta seção são apresentadas na FIGURA 49.

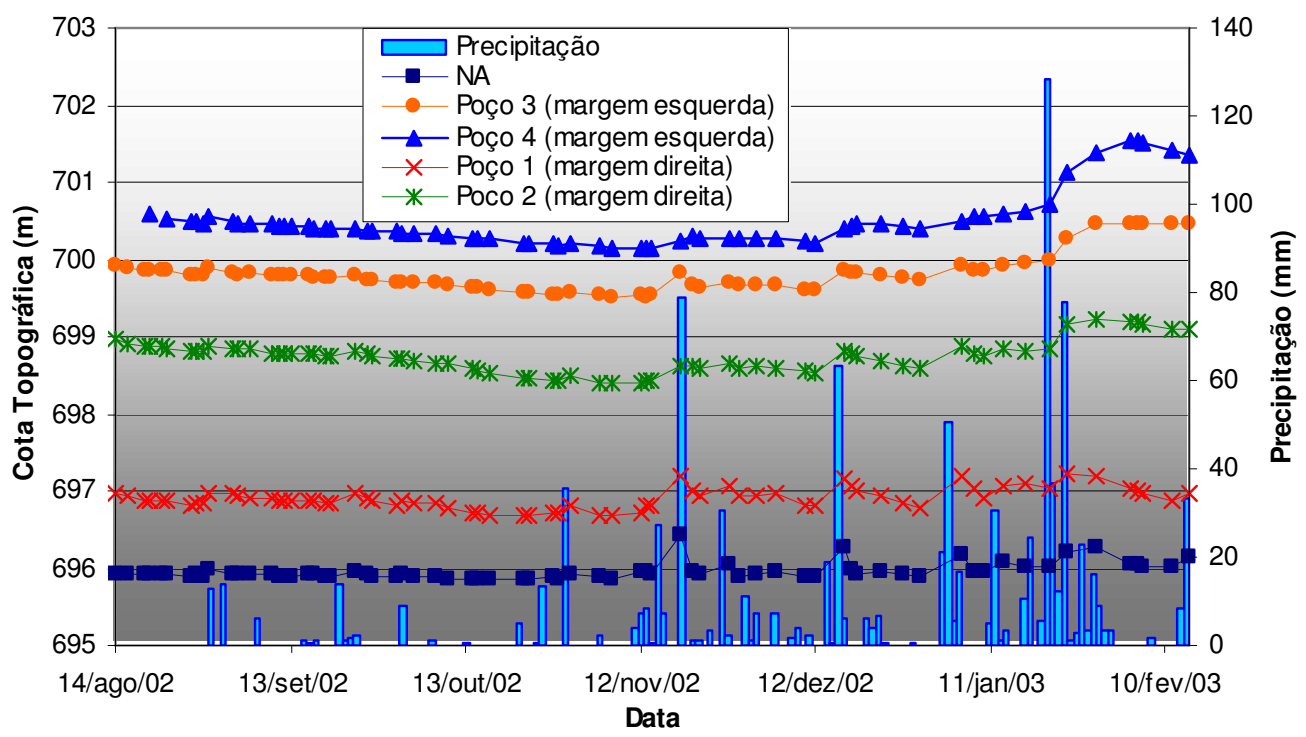

FIGURA 49 - Variações das cotas do nível d'água do rio e dos poços de observação próximo à seção 2 e precipitação. 
Analisando-se a variação dos níveis dos poços de observação, verifica-se que até meados de novembro o nível freático declinou devido à existência de pouco chuva, insuficiente para suprir as necessidades da capacidade de campo e recarregar o aqüífero. Em seguida, até meados de janeiro houve um aumento do nível freático de forma praticamente constante, devido a uma precipitação relativamente distribuída. No fim de janeiro, houve grandes precipitações que causaram um aumento rápido nos níveis freáticos, aumentando o armazenamento de água subterrânea na bacia.

Para uma melhor visualização da variação dos níveis freáticos, os poços foram representados na seção transversal obtida da topografia. Os níveis máximos, médios e mínimos do lençol freático são desenhados junto à topografia do terreno nas FIGURAS 50 e 51.

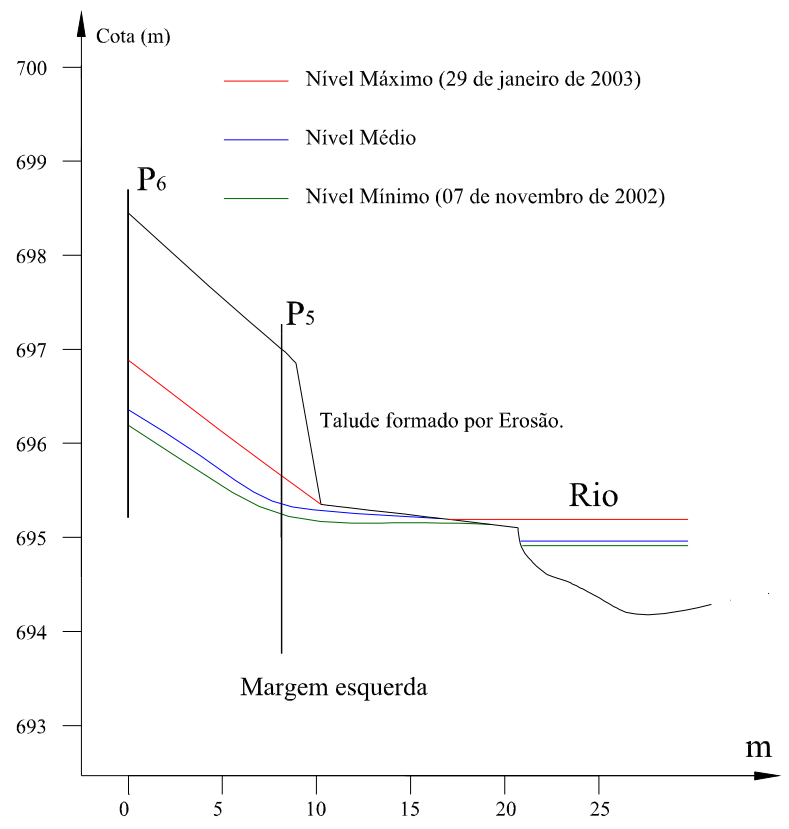

FIGURA 50 - Seção transversal para representação do nível freático na seção 1. 


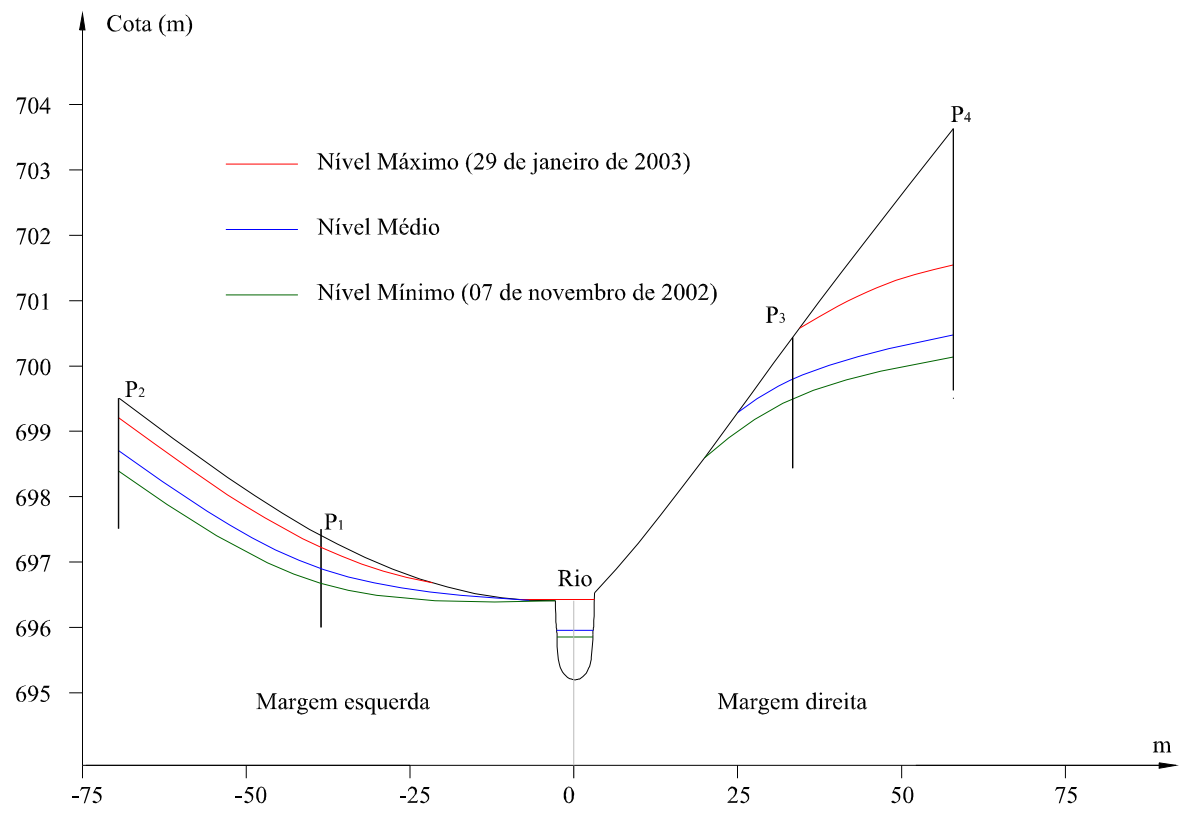

FIGURA 51 - Seção transversal para representação do nível freático na seção 2.

Analisando as representações das seções transversais de estudo, verifica-se que os níveis do lençol freático na margem esquerda, tanto para a seção de estudo 1 como a 2 , possuem uma forma côncava, diferentemente da forma convexa comumente observada sob encostas. Esse formato pode ser explicado pelo fato de haver a drenagem devido à existência de um 'braço' de rio desembocando na margem esquerda nas proximidades da seção 2. Já na seção 1, a existência de erosão na margem esquerda, devido à falta de mata ciliar, é responsável pelo formato do nível freático, marcado por grande variação na vizinhança do talude acentuado.

Verifica-se que em ambas a seções transversais houve um aumento na extensão da margem com afloramento. Essa área de afloramento maior proporciona o aumento do escoamento básico. 


\subsection{Análise da Influência da Pressão Atmosférica e da Cota do Rio sobre o Surgimento.}

Neste item será investigada a relação entre as grandezas medidas no trabalho, de modo a identificar uma possível interdependência, para um melhor entendimento dos fenômenos envolvidos.

A influência de variação da pressão atmosférica na taxa de surgimento foi observada no item 6.1. de apresentação dos dados coletados. Assim construíram-se gráficos para analisar tal influência durante os períodos de estiagem para as seções de estudo 1, 2 e 3. (FIGURAS 52, 53, 54).

Identificando-se períodos sem chuvas ou com precipitações diárias inferior a $5 \mathrm{~mm}$, construíram-se os gráficos

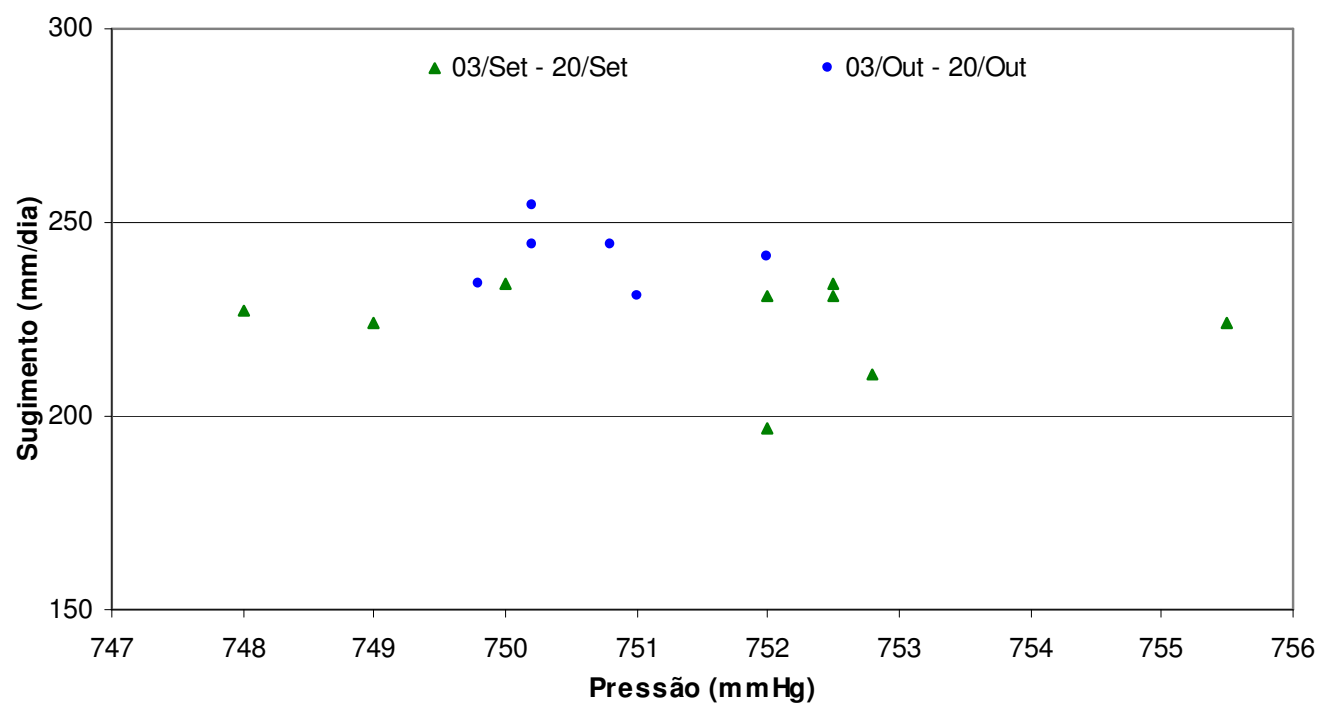

FIGURA 52 - Comparação entre os valores do surgimento e a pressão atmosférica na hora do ensaio, em épocas de estiagem (seção 1). 


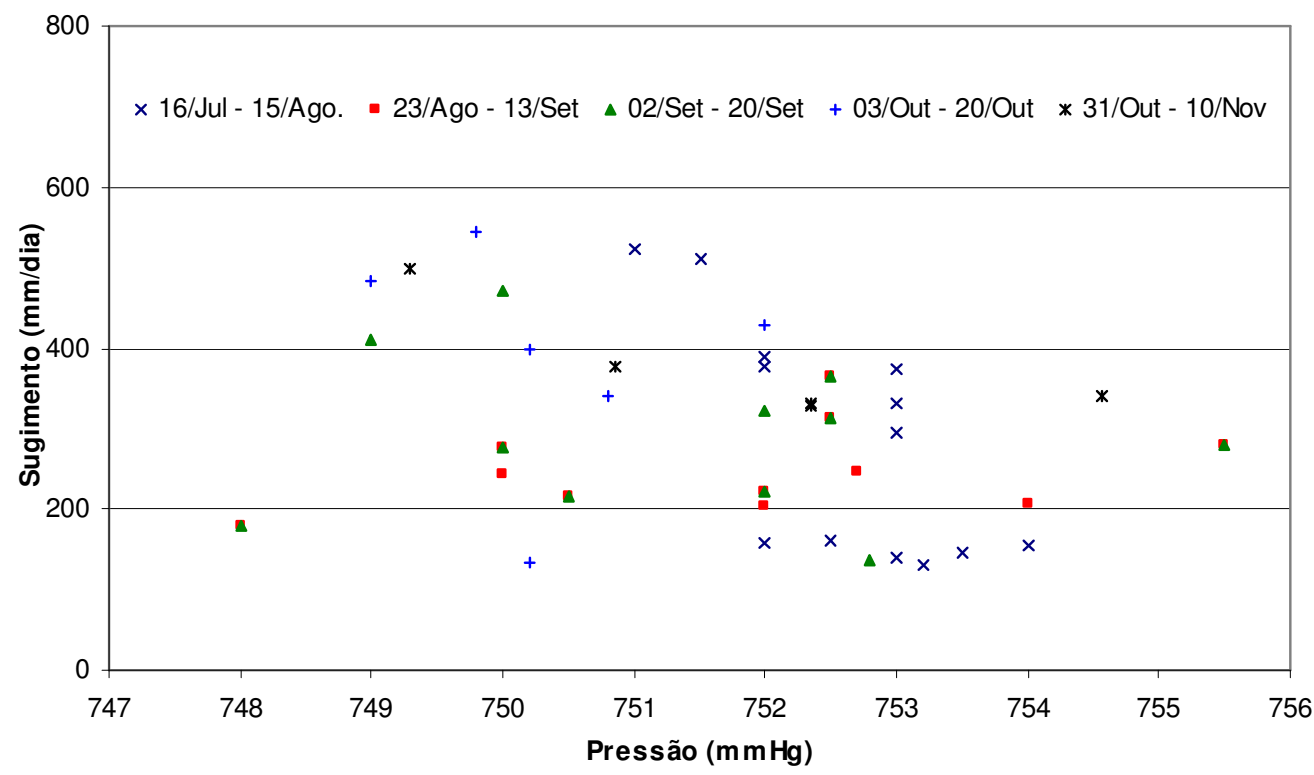

FIGURA 53 - Comparação entre os valores do surgimento e a pressão atmosférica na hora do ensaio, em épocas de estiagem (seção 2).

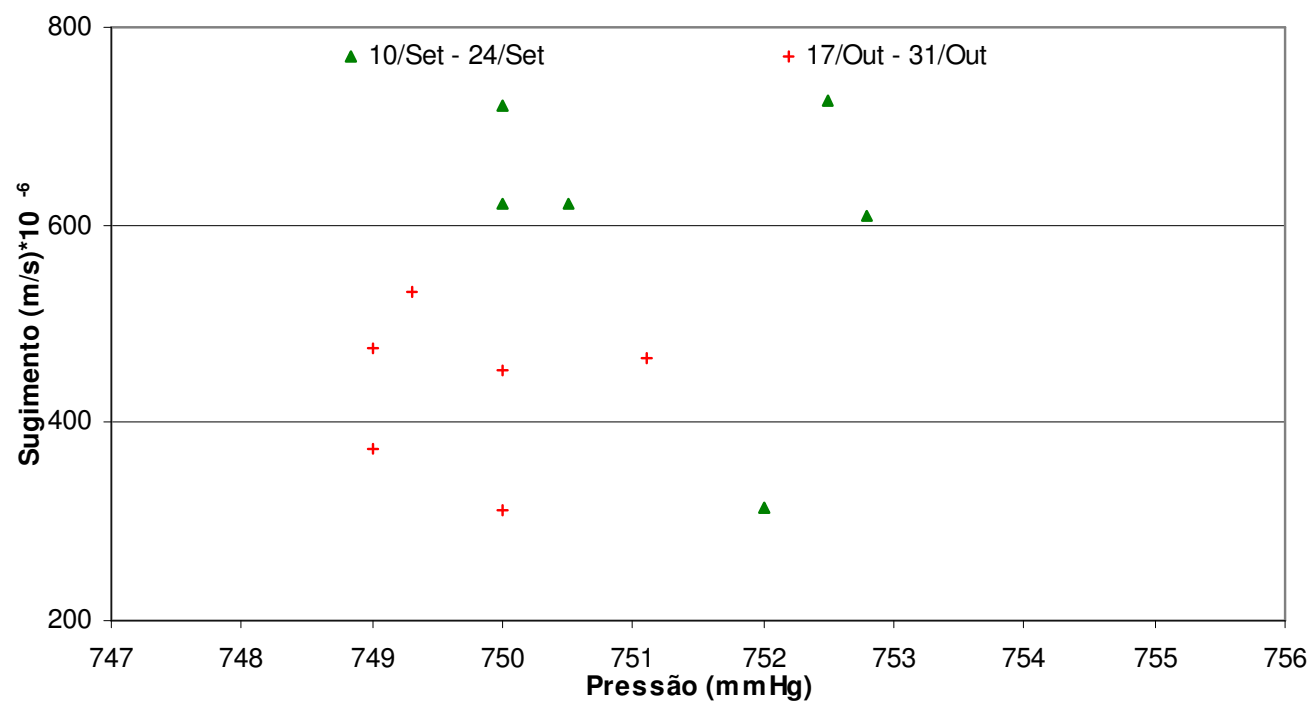

FIGURA 54 - Comparação entre os valores do surgimento e a pressão atmosférica na hora do ensaio, em épocas de estiagem (seção 3).

Pela análise dos gráficos da variação do surgimento com a pressão atmosférica verifica-se que a pressão atmosférica influencia inversamente a taxa de surgimento para a seção de estudo 2, durante a época de pouca chuva. Já para as seções de estudo 1 e 3 essa 
influência não é identificada. A explicação para essa diferença é que na seção 2 o rio afunilase tendo uma largura pequena comparado com as duas outras seções, e as suas margens possuem uma inclinação bem maior. Ainda, as seções 1 e 3 possuem áreas pantanosas em suas margens direitas. A existência de uma zona vadosa maior na seção 2 pode ser a explicação para essa maior influência da pressão atmosférica (PECK, 1960). A pressão atmosférica atua tanto no rio quanto no aqüífero, entretanto, ela atua diretamente sobre o rio (FIGURA 55) e indiretamente no lençol freático, sendo a região intermediária não-saturada, como um filtro amortecendo a variação instantânea da pressão.

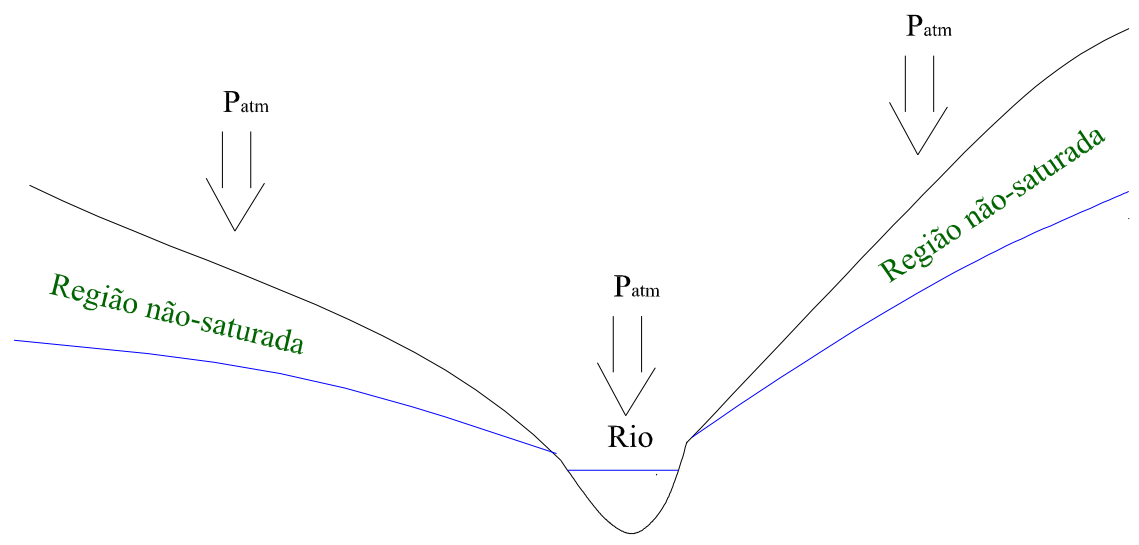

FIGURA 55 - Influência da pressão atmosférica.

Acredita-se que a taxa de surgimento sofra influência da cota do nível do rio, como foi descrito no item 6.1. sobre medidas da interação. O gráfico na FIGURA 56 mostra que o aumento do nível do rio devido ao aumento das chuvas causou uma diminuição na taxa de surgimento. Esse fenômeno, discutido anteriormente, se deve às diferentes taxas de aumento dos níveis do rio e do aqüífero. O aumento mais rápido do nível do rio provoca uma diminuição do diferencial de carga hidráulica entre o aqüífero e o rio. 


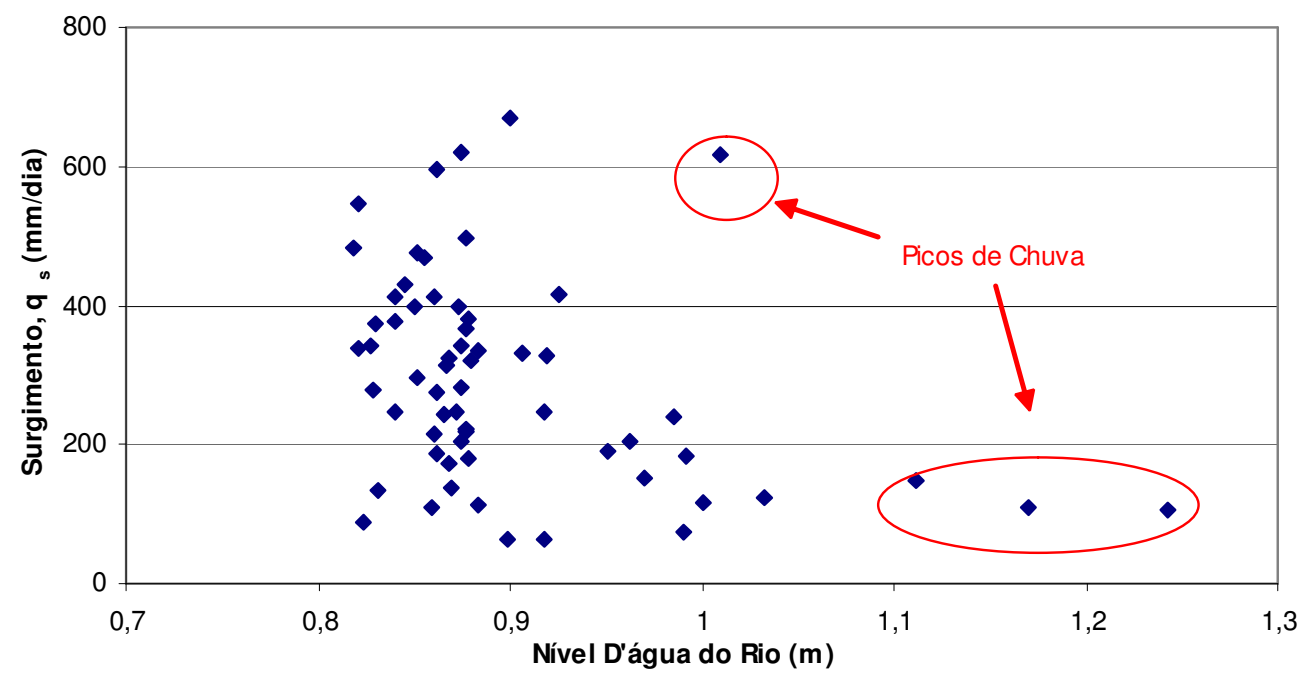

FIGURA 56 - Variação do Surgimento com o Nível d'água no Ponto 2.

\subsection{Considerações Finais e Sugestões.}

O trabalho experimental de campo requer muito empenho e busca de observações coerentes. Dificuldades variadas foram encontradas durante a fase de execução dos experimentos. No inicio, surgiram problemas relacionados à vedação das sacolas plásticas e ao entupimento na ligação entre o tambor e as próprias sacolas. Estes problemas foram resolvidos, substituindo-se as sacolas por um recipiente mais resistente e também aumentando o diâmetro de saída do tambor.

Nos meses de finalização dos experimentos de campo, houve um aumento na ocorrência das chuvas, o que ocasionou novos problemas. O aumento da velocidade da água no rio acelerou o carreamento do material de fundo, comprometendo a fixação do tambor de coleta das águas de surgimento, invalidando resultados de alguns experimentos. A recolocação do tambor no leito do rio pode apresentar condições diversas introduzindo erros nas medidas, pois dificilmente as condições anteriores seriam restabelecidas. Dificuldades em garantir as mesmas condições iniciais, como localização do tambor na 
recolocação e a própria variação da camada de sedimentos do fundo, podem influenciar as medidas da taxa de troca, dificultando a comparação entre ensaios anteriores.

Apesar das dificuldades, o infiltrômetro representa uma ferramenta útil para o conhecimento das taxas de trocas no fundo do rio. Uma forma seria a construção de um equipamento capaz de medir a taxa de troca de maneira contínua por meio de um "infiltrógrafo", onde fosse possível verificar melhor a influência da pressão atmosférica e quantificar a variação do escoamento básico de fundo. 


\section{CONCLUSÕES.}

O presente estudo teve como objetivos a determinação da variação temporal da taxa de troca no fundo do Ribeirão da Onça por meio de infiltrômetros e a instalação de poços para observação da variação do lençol freático na vizinhança do rio.

O estudo da interação rio-aqüífero foi realizado através de infiltrômetros em três seções do Ribeirão da Onça. Os infiltrômetros construídos na primeira etapa não apresentaram bons resultados e algumas mudanças foram necessárias para que o equipamento funcionasse. Com o aumento do diâmetro de saída da tubulação do tambor e a escolha de um recipiente plástico coletor mais resistente, conseguiu-se então quantificar a interação rio-aqüífero.

Foram realizados alguns testes para verificar a resistência ao escoamento na tubulação e no recipiente de plástico, concluindo que essa resistência era desprezível (Item 5.3.5).

Analisando-se o comportamento da interação ao longo dos dias, verificou-se que existe influência da chuva e da pressão atmosférica (seção 2) nos valores dos surgimentos sendo esta ultima de forma inversa (FIGURAS 43, 44, 52, 53, 54 e 56).

Os valores da interação nas seções de estudo 1, 2 e 3 possuem a mesma ordem de grandeza, apresentando um valor médio de $300 \mathrm{~mm} /$ dia (TABELA 02). Tal quantificação pode ser útil nos estudos da avaliação da recarga do aqüífero Guarani.

Foi possível relacionar, de forma aproximada, a taxa de surgimento de água no fundo do Ribeirão da Onça com o escoamento de base, obtendo valores próximos dos encontrados experimentalmente no campo (Item 6.3). 
Utilizando-se mini-piezômetros para medir o gradiente hidráulico de uma camada do leito do rio, juntamente com o valor da taxa de surgimento, foi possível determinar a condutividade hidráulica no fundo do rio. A condutividade encontrada com o minipiezômetro apresentou-se de mesma ordem de grandeza da sua estimativa obtida através da granulometria.

A variação dos níveis freáticos foi observado ser muito gradual no inicio dos experimentos (de meados e agosto até o inicio de novembro) devendo-se a baixa ocorrência de chuva nesse período (FIGURAS 48 e 49).

Com a chegada das chuvas (outubro) verificou-se que houve uma pequena diminuição na taxa de surgimento quantificada (FIGURAS 43 e 46). Acredita-se que o aumento do nível do rio tenha causado esse pequeno decréscimo, em resultado do diferencial reduzido de carga hidráulica que é a força motriz responsável pelo fenômeno do surgimento. Apesar da diminuição na taxa de surgimento de água no fundo do rio durante a época chuvosa, há aumento no escoamento de base dos hidrogramas devido à ampliação da região de afloramento nas margens do rio e conseqüente surgimento de água.

A existência de erosão e voçorocas nas margens devido à falta de mata ciliar provoca o rebaixamento do aqüífero freático, modificando o seu formato. Tal modificação torna côncava superfície freática, -diferentemente da forma convexa comumente observada sob encostas (FIGURAS 50 e 51).

Tendo em vista os experimentos realizados, resultados obtidos e as conclusões, a utilização de infiltrômetro para determinação da taxa de troca entre rio e aqüífero é válida, principalmente por se tratar de um equipamento barato No entanto, cuidados contínuos são requeridos para que esse equipamento funcione adequadamente e forneça resultados confiáveis. 


\section{REFERÊNCIAS BIBLIOGRÁFICAS.}

(1) BEAR, J. (1979). "Hydraulics of Groundwater", McGraw-Hill, New York.

(2) BOUWER, H. (1978). "Groundwater Hydrology”. McGraw-Hill, New York.

(3) BRAINARD, E. C. e GELHAR, L. W. (1991). "Influence of Vertical Flow on Ground-Water Transport”. Ground Water, 29(5), 693 - 701.

(4) CARR, M. R. e WIRTER, T. C. (1980). "An Annotated Bibliography of Devices Developed for Direct Measurement of Seepage”. Rep. n. 80-344 U.S. Geological Survey, Denver, Colorado.

(5) CASTRO, N. M. e HORNBERGER, G. W. (1991). "Surface-Subsurface Water Interaction in an Alleviated Mountain Stream Channel”. Water Resour. Res., 27(7), 1613 1621.

(6) CEY, E. E., RUDOlPH, D. L., PARKIN, G. W. e AREVERA, R. (1998). "Quantifying Ground Water Discharge to a Small Perennial Stream in Southern Ontario, Canadá”. J. Hydrol. (accepted for publication).

(7) CHEKAUER, D. A. e MCBRIDE, J. M. (1988). "A Remotely Operating Seepage Meter for Use in Large Lakes and Rivers”. Ground Water, 26(2), 165 - 171. 
(8) CONTIN, D. (1987). "Balanço Hídrico em Bacia Hidrográfica Situada em Região de Recarga do Aqüífero Botucatu". Tese de doutorado, Escola de Engenharia de São Carlos, Universidade de São Paulo.

(9) DE LOCZY, L. (1966). "Evolução Paleogeográfica e Geotectônica da Bacia Gonduânica do Paraná e do seu Embasamento”. Departamento Nacional de Produção Mineral, Ministério das Minas e Energia, Boletim nº 234, Rio de Janeiro.

(10) FREEZE, R.A. e CHERRY, J. A. (1979). "Groundwater". Prentice-Hall, Inc. Englewood Cliffs. NJ. 604 pp.

(11) GELDNER, P. (1980). "Deterministische und Stochastische Methoden zur Bestimmung der Selbstdichtung von Gewässern”. Mitteilungen, Heft 49, Instit für Wasserbau, Univ. Stuttgart.

(12) GELDNER, P. e KALERIS, V. (1980). “Zum Austausch Zwischen Grundwasser und Obserflächengewässern, eine Autbereitung des Nahfeldkonzepts für die Naturmesspraxis". SFB80/T/143, Sonderforschungsbereich 80, Univ. Karlsruhe.

(13) GILBOA, Y., MERO, F. e MARIANO, I. B. (1976). "The Botucatu Aquifer of South America, Model of an Untapped Aquifer". Journal of Hydrology, 29(1/2), 165 179.

(14) HARE, P. W. e MORSE, R. E. (1997). "Water Level Fluctuations Due to Barometric Pressure Changes in an Isolated Portion of an Unconfined Aquifer". Ground Water. vol 35, no. 4. p. 667-671. 
(15) HARVEY, J. W., WAGNER, B. J. e BENCALA, K. E. (1996). "Evaluating the Reliability of the Stream Tracer Approach to Characterize Stream-Subsurface Water Exchange". Water Resour. Res., 32(8), 2441 - 2451.

(16) HUISMAN, L. E OLSTHOORN, T. N. (1983). "Artificial Groundwater Recharge". Pitman Advanced Publishing Program, Boston.

(17) ISRAELSON, O. W. e REEVE, R. C. (1944). "Canal Lining Experiments in the Delta Area, Utah: Utah Agricultural Experimental Station”. Bulletin 313, 15 - 35.

(18) JACOB, C. E.(1940). "On the Flow of Water in an Elastic Artesian Aquifer". Trans, Am. Geophys. Union, 21: 574-586.

(19) KALERIS, V. (1986). "Erfassung des Austausches von Oberflächen - und Grundwasser in horizontalebenen Grundwassermodellen". Mitteilungen, Heft 62, Institut für Wasserbau, Univ. Stuttgart.

(20) KALERIS, V. (1998). "Quantifying the Exchange Rate Between Groundwater and Small Streams”. Journal of Hydraulic Research, Vol. 36, no. 6, 913 - 932.

(21) LEE, D. R. (1977). “A Device for Measuring Seepage Flux in Lakes and Estuaries”. Limnol. Oceanogr., 22(1), 140 - 147.

(22) LEE, D. R. e CHERRY, J. A. (1978). "A Field Exercise on Groundwater Flow Using Seepage Meters and Mini-Piezometers”J. Geol. Ed., 27, 6-10. 
(23) MATtos, A., RIGHETTO, A. M., CONTIN NETO, D. e POMPÊO, C. A. (1984). "Relações Hidrológicas e Hidrometeorológicas em Bacia Experimental na Região de Afloramento do Aqüífero Botucatu". Departamento de Hidráulica e Saneamento, EESC USP. Relatório apresentado à FAPESP. São Carlos.

(24) MEIGS, L. C. e BAHR, J. M. (1995). "Three-Dimensional Ground Flow Near Narrow Surface Water Bodies”, Water Resour. Res., 31(12), 3299 - 3307.

(25) PECK, A. J. (1960). "The Water Table as Affected by the Atmospheric Pressure". J. Geophys. Res., 65:2383-2388.

(26) POLUBARINOVA-KOCHINA, P. YA. (1962).“Theory of Ground Water Movement" Translated from the Russian by J. M. R. de Wiest, Princeton Univ. Press, Princeton, New Jersey.

(27) POMPÊO, C. A. (1990). " Balanço Hídrico da Zona Não-Saturada do Solo na Bacia do Ribeirão da Onça (SP)”. Departamento de Hidráulica e Saneamento, EESC - USP. Tese de Doutorado. 177 p.. São Carlos.

(28) PRETO FILHO, V. O. (1985). "Implantação de uma Bacia Experimental para Estudos Hidrogeológicos e Hidrometeorológicos". Departamento de Hidráulica e Saneamento, EESC - USP. Primeiro relatório semestral jan. - agos., apresentado à FAPESP. 16p.. São Carlos.

(29) TANCO, R e KRUSE, E (2001). "Prediction of Seasonal Water-Table Flutuations in La Pampa and Buenos Aires, Argentina”. Hydrogeology Journal, 9(4): 339 - 347. 
(30) TODD, D. K. (1967). "Hidrologia de Águas Subterrâneas", Edgard Blucher, São Paulo, 319 p.

(31) TRAUB, R. (1982). "Austausch Zwischen Oberflächen - und Grundwasser”. 4 Forbildungslehrgang "Grundwasser" in Darmstadt, DVWK, Bonn.

(32) TUCCI, C. E. M. (2001). "Hidrologia: Ciência e Aplicação". 2ª Edição. Porto Alegre: Ed. Universidade/ UFRGS: ABRH. 943 p.

(33) TURK, L. J. (1975). "Diurnal Fluctuation of Water Table Induced by Atmospheric Pressure Changes". Journal of Hydrolog, 26: 1-16.

(34) UNESCO/ROSTLAC (1982). "Guía Metodológica para la Elaboración del Balance Hídrico del América del Sur”. 130 p.. Montevidéu, Uruguay.

(35) WEEKS, E. P. (1979). "Barometric Fluctuations in Wells Tapping Deep Unconfined Aquifers". Water Resources Research. v. 15, no. 5, pp. 1167-1176.

(36) WINTER, T. C. (1981). "Uncertainties in Estimating the Water Balance in Lakes". Water Resources Bulletin, 17(2), $82-115$.

(37) WINTER, T. C.; HARVEY J. W.; FRANKE, O.L.; ALLEY, W.M. (1998). "Ground Water and Surface Water. A Single Resource”. U. S. Geological Survey Circular 1139. 79 p.. 
(38) WROBLICKY, G. J., CAMPANA, M. E., VALETT, H. M. e DAHM, C. N. (1998). "Seasonal Variation in Surface-Subsurface Water Exchange and Lateral Hyporheic Area of Two Stream-Aquifer Systems”. Water Resour. Res., 34(3), 317 - 328.

(39) YORK, J. P., PERSON, M., GUTOWSKI, W. J., WINTER, T. C. (2002). "Putting Aquifers into Atmospheric Simulation Models: an Example from the Mill Creek Watershed, Northeastern Kansas”. Advances in Water Resources. 25(2): 221 - 238. 